\title{
Methane Emissions Against the Background of Natural and Mining Conditions in the Budryk and Pniówek Mines in the Upper Silesian Coal Basin (Poland)
}

Marcin Dreger ( $\nabla$ marcin.dreger@interia.pl )

University of Silesia: Uniwersytet Slaski w Katowicach https://orcid.org/0000-0002-7250-2523

\section{Sławomir Kędzior}

Uniwersytet ?!?ski w Katowicach: Uniwersytet Slaski w Katowicach

\section{Research}

Keywords: methane emissions, the Upper Silesian Coal Basin, Budryk Mine, Pniówek Mine, hard coal output

Posted Date: December 17th, 2020

DOI: https://doi.org/10.21203/rs.3.rs-127349/v1

License: (c) (i) This work is licensed under a Creative Commons Attribution 4.0 International License. Read Full License

Version of Record: A version of this preprint was published at Environmental Earth Sciences on November 1st, 2021. See the published version at https://doi.org/10.1007/s12665-021-10063-4. 


\section{Abstract}

The paper presents the variability of hard coal output, methane content and methane emissions into coal workings and into the atmosphere from the two most methane-gassy coal mines in Poland, Budryk and Pniówek, which are both incorporated in the Jastrzębie Coal Company. The Budryk mine is one of the youngest mines in Poland, but it is the most methane-gassy as well. In 2016, the total $\mathrm{CH}_{4}$ emissions exceed 140 million of $\mathrm{m}^{3}$. This large increase in methane emissions to mine workings is primarily related to the increase in the depth of coal extraction (up to $1290 \mathrm{~m}$ ) and, consequently, the rapid increase in the methane content in coal seams (up to 10-12 $\mathrm{m}^{3} / \mathrm{Mg}_{\text {coaldaf }}$ ). On the other hand, in the Pniówek mine, methane emission was the highest at the beginning of the study period (1986-1991). During the following years emission decreased to the values of less than 140 million of $\mathrm{m}^{3}$, which were still one of the largest amounts of emitted methane in the entire Upper Silesian Coal Basin. The vertical distribution of methane content, different than in the Budryk mine, and the presence of a secondary high methane zone at the Carboniferous top, seem to be decisive for the long-term distribution of methane emissions in the Pniówek mine. The coexistence of natural factors, such as the geological structure and gas distribution, as well as mining-related factors, i.e. the depth of mining, the concentration of coal extraction determines the temporal variability of methane emissions in the studied mines.

\section{Introduction}

The Upper Silesian Coal Basin (USCB) (Fig. 1) is the most industrialised region in Poland, providing bituminous coal for heat and power generation, as well as coking coal for coke production. To maintain profitability and keep the output at the highest possible level, hard coal is extracted from deeper seams, while natural hazards have been increasing every year (Dreger and Kędzior 2019). Reaching deeper coal seams carries a high methane risk, a risk of underground tremors, and intensification of temperature hazards. The increase of methane emission is one of the most dangerous problems in modern mining activity and entails work suspension, evacuations and even fatalities after methane explosions (Duda and Krzemień 2018; Dreger and Kędzior 2019). Two mines from the USCB were chosen to identify and study variations in methane emissions. Budryk and Pniówek coal mines are members of the Jastrzębie Coal Company, one of the largest coal enterprises in Poland. These two mines are also characterised by the highest $\mathrm{CH}_{4}$ emission in the entire coal basin in Poland. Methane emissions to coal workings in the studied mines are often more than 100\% higher than in other mines in the basin (Report 1995-2019). The absolute methane emission in the Upper Silesian

Coal Basin has been changing with time. In 2004, methane emission from all mines amounted to more than 800 million $\mathrm{m}^{3}$ and in 2015 exceeded 900 million $\mathrm{m}^{3}$. The entire emission values fluctuated from year to year, but the overall emission trend is increasing. A similar trend was observed in other coal basins, where coal was extracted from deeper levels every year (e.g. Ju et al. 2016). On the other hand, the hard coal output in Poland has been constantly decreasing from over 100 million Mg at the end of the $20^{\text {th }}$ century to around 60 million $\mathrm{Mg}$ in 2016-2018. Methane $\left(\mathrm{CH}_{4}\right)$ is the second most important greenhouse gas after the notorious carbon dioxide $\left(\mathrm{CO}_{2}\right)$. Methane plays a potent role in atmospheric chemistry and radiation balance. The infrared radiation power of methane exceeds the radiation power of carbon dioxide 21-25 times. Methane persists in the atmosphere for 9 to 15 years (Warmuziński 2008; Ghosh et al. 2015). The main global $\mathrm{CH}_{4}$ emitters are landfills, cattle farming, rice cultivation, coal mining and industrial processes. The global hard coal mining is responsible for $6 \%$ of the global methane emissions (Warmuziński 2008, Yusuf et al. 2012, Kędzior 2015, Harvey 2020). International agreements, such as Kyoto Protocol (1997), Paris (2015) and Katowice (2018) Agreements, tend to limit greenhouse gases emission worldwide to stop the Earth's temperature increase. One of the idea is to include methane gas in the list of greenhouse gases for emission of which fees will have to be paid.

The amount of methane emission from a coal deposit is strictly dependent on many factors, which can be roughly divided into natural factors related to the geological structure of the deposit and its natural gas content and pressure, as well as anthropogenic causes resulting from mining activities and the method of deposit exploitation (e.g. Karacan et al. 2011; Kędzior and Dreger 2019, Dreger 2020). Therefore, the interrelationship of available results regarding the gas content of the deposit, volume and concentration of coal extraction with the data on the quantity of methane emissions should make us aware of how strongly the described factors affect the phenomenon of emissions and, therefore, how to counteract it.

Accordingly, the main purpose of this article is to show how the dependencies and causes of methane emission and hard coal output have changed with time (1986 -2018) in the two most methane-gassy coal mines in Poland. The Pniówek coal mine is

Page 2/52 
characterised by the one of the highest methane emissions in Poland. In the Budryk mine, methane emission has been increasing rapidly since 2013 and now it is the highest in the country.

\section{Methods}

All the data were obtained from officially accepted geological documentation from the Budryk and Pniówek mines belonging to the Jastrzębie Coal Company (JCC internal report). In addition data from the Annual Report (for the years 1994-2018) on the state of basic natural and technical hazards in the hard coal mining industry published by the Central Mining Institute (GIG) in Katowice (Report 1995-2019) and the State Mining Authority in Katowice publication - Statystyki Wypadków (Accident Statistics) (State Mining Authority 2019) were taken for calculations and analyses. Moreover, to study relations between methane content and coal seam pressure (methane desorption), data collected by Tarnowski (1971) and CLP-B Mining Laboratory in Jastrzębie-Zdrój were also considered and carefully analysed.

The most important data taken into account in this research is the methane emission from two selected underground coal mines

- Budryk and Pniówek. The absolute (total) methane emission refers to methane liberated from the coal and surrounding rock strata due to mining activities (e.g. Coal Mine Methane Sources; Working Mine Methane). It is a combination of ventilation air methane (VAM emission) and methane produced by coal seam drainage (degassing). VAM emission and degassing were also studied for these two coal mines. The VAM emission is derived from the rate of air flow in the ventilation duct measured by $\mathrm{CH}_{4}$ detectors (Gawlik and Grzybek, 2002; Kędzior and Dreger 2019) and calculated using the following formula:

$\mathrm{Q}=\mathrm{VSC} / 100$, where

$Q$ is the volume of liberated methane [million $\mathrm{m}^{3} /$ year],

$S$ is the cross sectional area of the ventilation duct $\left[\mathrm{m}^{2}\right]$,

$V$ represents air flow rate [million $\mathrm{m} /$ year],

$C$ is the methane concentration in ventilation air [\%].

Methane captured by underground drainage systems (degassing) is measured by industrial gas meters and methane detectors that record $\mathrm{CH}_{4}$ concentration in the air mixture (Gawlik and Grzybek 2002).

Specific $\mathrm{CH}_{4}$ emission was investigated as well. It describes how many $\mathrm{m}^{3}$ of gas are liberated to coal workings with every single $\mathrm{Mg}$ of extracted coal. The specific methane emission is calculated using the following formula:

$\mathrm{Esp}=\mathrm{Et} / \mathrm{Pc}$, where

Esp is the specific methane emission $\left[\mathrm{m}^{3} \mathrm{CH}_{4} / \mathrm{Mg}\right.$ of coal],

Et is total methane emission [million $\mathrm{m}^{3} /$ year]

Pc is hard coal output [million Mg / year].

To measure the threat of $\mathrm{CH}_{4}$ adsorbed in coal, we use the term methane content, which describes the volume of gas in one $\mathrm{Mg}$ of

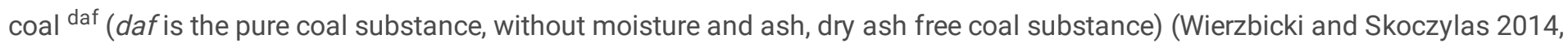
Honysz 2015). Methane content in Polish coal seams is determined by the certified mining laboratories (e.g CLP-B Mining Laboratory, Central Mining Institute) and Katowice Geological Enterprise, by analysing coal samples in hermetic containers by means of vacuum degasification, followed by the calculation of the $\mathrm{CH}_{4}$ content (Kotas 1994, Kędzior 2009, Honysz 2015, Krause 2019).

The desorption intensity which defines the coal seam pressure is performed by 'desorbometer', a device in which very small diameter drill cuttings are placed. The releasing methane from coal sample (desorption intensity) is red on the vertical scale in $\mathrm{kPa}$ 
(e.g. Skoczylas and Wierzbicki 2014). In Polish coal mines, the maximum safe value of the desorption indensity index ( $d p)$, measured by means of a manometric desorbometer is set as $1.2 \mathrm{kPa}$ (e.g. Lama and Bodziony, 1998, Stączek and Simka 2004). According to Regulation of the Ministry of Economy (2002), the desorption intensity can be measured only with desorbometer, type DMC-2 (Fig.2).

Besides the gas data, the geological structure of the deposits, lithology, tectonics and technical parameters of operating longwalls were also considered. After the analysis of all collected data, the charts and tables representing the total methane emission, degassing, VAM emission, specific $\mathrm{CH}_{4}$ emission, methane pressure in the coal seam, methane emission intensity and the outline of geology framework were set up.

\section{Coal Mines Under Study}

\subsection{Budryk Mine}

The Budryk coal deposit is located in the northern part of the basin (Fig. 1) at the north-western flank of the Main Trough between two dislocations: the Kłodnica Fault in the north and the Bełk Fault in the south.

The Budryk deposit is composed of 43 documented coal seams (from 325 to 407/3), all of which are found in the Orzesze and Ruda beds. The deposit has a diverse geological structure, sediment disorders, and large tectonic variability. Carboniferous top surface varies in depth from $+60 \mathrm{~m}$ in the north to $+300 \mathrm{~m}$ above sea level in the south-east. The dip of the beds is varied, from almost horizontal to inclined at $15^{\circ}$ angle. The highest variability is found in single beds where layers incline to the south and south-east. Most of the seams are characterised as thin being less than $1.5 \mathrm{~m}$ thick and medium being 1.5-3.0 $\mathrm{m}$ thick. Some beds have a thickness of over $3 \mathrm{~m}(358 / 1,401,405 / 1,405 / 2)$, with the average thickness between $0.6 \mathrm{~m}$ and $3.81 \mathrm{~m}$.

The basic tectonic structure of Carboniferous deposits was formed during Variscan orogeny and was rejuvenated during the Alpine orogeny (Teper and Sagan 1995). In most of the Budryk area, the displacement direction is SES and extension direction is SWW-NEE, but in the western area it changes direction to SW-NE with a SE throw. The Carboniferous system is rich in many latitudinal and SW-NE, NW-SE faults. Table 1, Figure 3 and 4 show the characteristics of selected main faults in the Budryk and Pniówek mining area.

The largest dislocations in the USCB such as the Kłodnica, Książ or Bełk faults have nearly latitudinal orientation and displace layers to the south (Kędzior et al. 2013; Dreger and Kędzior 2019).

Table 1 Characteristics of the main faults in the Budryk and Pniówek mining areas (JCC internal report). 


\begin{tabular}{|c|c|c|}
\hline & Budryk & Pniówek \\
\hline \multicolumn{3}{|l|}{ Latitudinal direction } \\
\hline \multirow[t]{8}{*}{ Name/ throw size / throw direction } & Dębieńsko/ 25-45m/ N & Krzyżowice I / 20m / NW \\
\hline & Barbara Fault Zone/ 30-55m / S & Krzyżowice II / 25m / NW \\
\hline & North / 25m / N & Pniówek / 3-25m / S \\
\hline & Knurów / 30-100m/ SE & Skrzeczkowice / 70m / NNE \\
\hline & Paniowy / 25-26m / SE & $\mathrm{P}-1$ * / 15-22m / S \\
\hline & Śmiłowice / 15-65m / NW & \\
\hline & Barbara I / 30m / SE & \\
\hline & Paniówki / 8.5-20m / SW & \\
\hline \multicolumn{3}{|l|}{ Longitudinal direction } \\
\hline \multirow[t]{7}{*}{ Name/ throw size / throw direction } & Chudecki / 0.7-20m / W & Pawłowice I / 40-80m / W \\
\hline & & Pawłowice II / 60-100m / W \\
\hline & & Warszowice / 4-60m / E \\
\hline & & Graniczny I / 10-100m / NE \\
\hline & & Graniczny II / 10-30m / NW \\
\hline & & Graniczny III / 20m / NE \\
\hline & & $\mathrm{P}-2, \mathrm{~W}-2^{\star \star} / 5-20 \mathrm{~m} / \mathrm{E}$ \\
\hline
\end{tabular}

* Unnamed fault which divides part of the P-1 deposit in the north and south

** Unnamed faults which divide part of the P-2 and W-2 deposits in the east and west

In 1972 the Polish Geological Institute (PIG) divided the Carboniferous strata in Poland into stratigraphic units (presented in Table 2, modified after Gabzdyl and Gorol 2008). This division was adapted to the international Carboniferous division recommended by the International Stratigraphic Commission (Heckel, 2004; Table 2).

According to the presented units, the Budryk and Pniówek coal mines, all of the important coal seams, both exploited and not exploited, were documented.

The Budryk mining area is represented by the Pennsylvanian Upper Silesian Sandstone Series (Namurian C; Serpukhovian and Bashkirian) and the Mudstone Series (Westphalian A and B; Bashkirian) (Table 2). In the profile of documented Ruda coal deposit (Westphalian A; Bashkirian), Orzesze and Załęże (Westphalian B; Bashkirian) Beds were found.

The Upper Silesian Sandstone Series is represented by Ruda Beds occurring below the 407 seam where coarse and fine-grained sandstones were found. The Ruda coal seams were not documented, due to the deposition depth being too large. The following Załęże and Orzesze Beds (Westphalian A and B; Bashkirian) occur in all of the area with 800-1250 m thickness in total. They constitute the main stratigraphic unit in the deposit, built of mudstones, claystones and sandstones, with numerous coal seams which are the subject of mining. Claystones and mudstones have siderite concretions. Sandstones are mostly fine-grained, sometimes medium and coarse-grained, turning into conglomerates near the Carboniferous top. The thickness of coal seams vary from 0.6 to $3.5 \mathrm{~m}$. In the Orzesze and Załęże Beds, more than 30 coal beds were documented (from 325 to 406), being usually adjacent to claystones. Coal seams are characterised by possible splits and shrinking. Two freshwater fauna levels were noticed - between 404/2 - 404/4 and 405/2- 407 seams. 
Table 2 Upper Silesian Coal Basin stratigraphic division - modified after Heckel (2004) and Gabzdyl and Gorol (2008), C Carboniferous, $\mathrm{M}$ - Mississippian, P - Pennsylvanian

\begin{tabular}{|c|c|c|c|c|c|c|}
\hline \multicolumn{5}{|c|}{ Stratigraphic division } & Lithostratigraphic series & Layers \\
\hline \multicolumn{3}{|c|}{$\begin{array}{l}\text { International (after Heckel, } \\
\text { 2004) }\end{array}$} & \multicolumn{2}{|c|}{$\begin{array}{l}\text { Local (modified after Gabzdyl and Gorol, } \\
\text { 2008) }\end{array}$} & & \\
\hline \multirow[t]{14}{*}{ C } & \multirow[t]{10}{*}{$\mathbf{P}$} & \multirow[t]{2}{*}{ KASIMOV } & \multirow[t]{2}{*}{ STEPHANIAN } & B & \multicolumn{2}{|l|}{ Kwaczała Arkose } \\
\hline & & & & A & \multicolumn{2}{|l|}{ Stratigraphic Gap } \\
\hline & & \multirow[t]{2}{*}{ MOSCOVIAN } & \multirow[t]{4}{*}{ WESTPHALIAN } & D & \multirow[t]{2}{*}{ Cracow Sandstone Series } & Libiąż \\
\hline & & & & C & & Łaziska \\
\hline & & \multirow[t]{6}{*}{ BASHKIRIAN } & & B & \multirow[t]{2}{*}{ Mudstone Series } & Orzesze \\
\hline & & & & A & & Załęże \\
\hline & & & \multirow[t]{7}{*}{ NAMURIAN } & C & \multirow[t]{2}{*}{ Upper Silesian Sandstone Series } & Ruda \\
\hline & & & & B & & Saddle \\
\hline & & & & A & Paralic Series & Poruba \\
\hline & & & & & & Jaklovec \\
\hline & \multirow[t]{4}{*}{ M } & \multirow[t]{3}{*}{ SERPUKHOVIAN } & & & & Hrusov \\
\hline & & & & & & Pietrkovice \\
\hline & & & & & $\begin{array}{l}\text { Diastrophic sea deposits (flysch } \\
\text { type) }\end{array}$ & $\begin{array}{l}\text { Kyjovice } \\
\text { (upper) }\end{array}$ \\
\hline & & VISEAN & UPPER VISEAN & & & $\begin{array}{l}\text { Kyjovice } \\
\text { (lower) }\end{array}$ \\
\hline
\end{tabular}

Most of the Orzesze strata and the entire Carboniferous younger series (Cracow Sandstone Series) were removed by erosion in the mine area under study.

The overburden rocks lie discordantly on the Carboniferous erosion surface and consist of Triassic sandstones and carbonates, Miocene clays, as well as fluvial and glacial sediments of Quaternary origin. The total thickness of the overburden strata does not exceed $200 \mathrm{~m}$ (Table 4).

\subsection{Pniówek Mine}

The Pniówek coal deposit is located in the south-western part of the USCB (Fig. 1) at the SW limb of the Main Trough, bordering with the Bzie-Chechowice fault zone in the south. The Pniówek coal deposit is a multilayer structure consisting of 62 documented seams of various thicknesses and qualities of the beds. Tectonic character of the deposit is also very complex, with fault throws between 10 and $300 \mathrm{~m}$ (Table 1, Fig. 4). The Pniówek coal deposit has a monoclinic structure and a variable dip direction. Coal seams are found between 223-1300 m below ground level. Many claystone complexes occur between coal seams. Furthermore, we can distinguish many smaller faults accompanying larger dislocations throwing down the layers by a few metres.

The lithological profile of the Carboniferous strata within the discussed mine comprises the Pennsylvanian Paralic (Namurian A; Serpukhovian, Bashkirian), Upper Silesian Sandstone (Namurian B and C, Bashkirian), and Mudstone (Westphalian A and B; Bashkirian) Series.

The Poruba Beds (Namurian A; Bashkirian), the only prospected element in the Paralic series within the studied area, are built of mudstones and claystones with marine fauna. Minor formations include fine and medium grained sandstones and a few thin coal seams which have not been documented and operated. 
The Saddle Beds (Namurian A and B; Bashkirian) occur at depths between 1000 and $1500 \mathrm{~m}$ and are built of fine, medium, and coarse-grained sandstones with some conglomerate inserts. It is the tendency of coal seams to start splitting in the eastern part and merge in the western part of the deposit. Up to the depth of $1300 \mathrm{~m}$ coal beds ranging from $0.8 \mathrm{~m}$ (the seams numbered by $501,504,505,506,507,508)$ to $4.3 \mathrm{~m}(506)$ were documented. Below the depth where coal seams were documented and thoroughly examined, the thickest seam, numbered 510, occurs (thickness 4.5-12.2m) and is present at the base of the documented coal deposit. The Ruda (Namurian C; Bashkirian) Beds are represented by sandstones with claystones, mudstones, and coal inserts. Sandstones are fine, medium, and coarse-grained with conglomerates; claystones and mudstones are in the minority. The maximum thickness of the Ruda Beds is $700 \mathrm{~m}$.

The Załęże Beds (Westphalian A; Bashkirian) are composed of claystone and mudstone facia with sandstones and numerous, although not thick, coal seams. The maximum thickness of the Załęże Beds is $900 \mathrm{~m}$. There were 42 documented coal seams in these beds. Claystones, mudstones (97\%) are dominant, and sandstones (3\%) occur in the lithological profile. Coal beds lie close to claystones (grey with variable sand contents and fauna), rarely with sandstones (fine-grained with clay or clay-silica matrix). Coal seams are very numerous, but irregular with different thickness. Similarly to the Budryk mine area, Carboniferous deposits younger than the Załęże Beds were removed by erosion.

The Carboniferous top surface displays an erosive character and is morphologically varied. There are many paleo-ridges and washouts with a general NW orientation. The differences in height of individual sites reach several hundred metres. There are clay and sandy Miocene deposits on the eroded Carboniferous surface. Their thickness is variable and ranges from about $200 \mathrm{~m}$ in the north to $1000 \mathrm{~m}$ in the south (Table 4). Grey compact clays of the Skawina formation predominate, only in the depressions of the Carboniferous top surface sands and gravels are typical. Quaternary glacier tills and sands occur in the uppermost part in the entire study area.

\section{Methane Hazard And Emission Against The Geological Background Of The Upper Silesian Coal Basin - An Overview}

\subsection{Geological background}

The USCB sedimentary basin was developed during the Variscan orogeny (Kotas, 1990, 1995). The coal-bearing Carboniferous strata filling the Upper Silesian depression are of molasses type (Kotas 1990). The total thickness of the Upper Carboniferous profile reaches $6000-7000$ metres. Over 400 coal seams and inserts were found in the Upper Carboniferous profile, about 260 of them are of industrial use. The total thickness of balance coal seams up to the depth of $1000 \mathrm{~m}$ is about $65 \mathrm{~m}$ in maximum, 20-30 $\mathrm{m}$ on average.

The USCB's total hard coal balance resources are 52.24 billion tonnes as of December $31^{\text {st }} 2019$ (Malon and Tymiński, 2020). At the end of the Permian period, the denudation and weathering processes of uplifted Paleozoic strata started and lasted throughout all of the Mesozoic and Early Cenozoic period (Kozłowski and Grębski 1982; Kotarba, 2001). According to models of Carboniferous sediment erosion (e.g. Kosakowski et al., 1995), approximately 250-1700 m of Carboniferous deposits were removed due to erosion before the Miocene period in the USCB western and central parts, however in the south-western part of USCB and in the Czech part of the basin, the profile was reduced by weathering processes to 3000-4000 metres (e.g. Gerslova et al., 2016, Kędzior, 2019). The result is the now evident erosive nature of the morphologically varied Carboniferous top surface. In the Miocene, the USCB area was flooded by sea. Thick and continuous shale layers were deposited directly on the weathered Carboniferous strata (Section 2). As a result of that deposition, a hermetic and impermeable overburden is present today (Kozłowski and Grębski 1982; Kotas 1994; Kędzior 2009, 2019). This applies to the Pniówek mine located in the southern part of the basin, where the thickness of the Miocene overburden reaches $900 \mathrm{~m}$ (Table 4, Fig. 4). The current distribution of the gas content is a result of combination of various factors responsible for the migration and accumulation of gases, such as type of rocks surrounding the coal seams, lithology kind of coal series overburden, etc. The lack of a sealing overburden of the coalbearing series and the intense erosion of coal-bearing formations in the past, as well as the presence of porous and permeable sandstones surrounding the coal seams may contribute to the degassing of large areas of the deposit located shallower. This is especially true of the northern and eastern part of the basin, where the not too thick Triassic, Jurassic and Miocene overburden do not provide sufficient sealing for migrating gases (e.g. Kotas, 1994; Kotarba, 2001). According to the latest research (Słoczyński 
and Drozd, 2018), fault tectonics played a significant role here. Faults are natural migration pathways for methane, thus contributing to the degassing of fault zones. This applies in particular to large faults with NW-SE orientation, such as the Kłodnica or Bzie-Czechowice faults. Around these faults, a several-hundred-meter zone of reduced gas pressure and gas content of the seams were observed (Tarnowski, 1989). Faults with a similar longitudinal orientation tend to trap gases on their western side, which is evident in the form of increased gas content. Faults in the northern part of the basin have such features (Tarnowski, 1989). A number of faults, it is even estimated that there are about $50 \%$ of them, at deeper levels (about $1000-1250 \mathrm{~m}$ ) they degass the deposit, and at shallower levels they saturate. Thus, they are natural methane migration pathways and they are the ones that may contribute to the gas flow to the mine workings. According to Tarnowski (1989), these faults have a longitudinal orientation.

Fault zones are often accompanied by structurally altered coals in crushed or mylonitic form. Such coal is characterized by greater porosity, permeability and fracture occurrence in relation to unchanged coal. Therefore, such coal is able to accumulate free gas under pressure in the form of the so-called gas pockets (Kędzior and Dreger, 2019). This gas, due to the disturbance of the rock mass during coal mining, may rapidly flow into the excavation as an ejection or outburst.

\subsection{Methane hazard}

Methane $\left(\mathrm{CH}_{4}\right)$, as one of the simplest gases occurring in nature, has been associated with coal deposits from the beginning, since the time when the coalification process of the organic substance started (e.g. Hunt 1991, Lunarzewski 1998). Methane is known also as 'mud gas' present in peatlands and wetlands. Peat bog is the first step to change organic substance into lignite and then into hard coal. At every stage $\mathrm{CH}_{4}$ accompanies these developments as a product of coalification process based on complex chemical reactions leading to increase in carbon content and decrease in hydrogen content in coal substance (e.g. Hunt 1979, 1991; Kędzior 2019). Methane associated with coal occurs today in two forms, namely as adsorbed and free gas. Gas sorption capacity depends on temperature, pressure, the type and rank of coal (e.g. Scott, 2002; Kędzior, 2009). Free methane fills voids, breaks and pores in coal beds and surrounding rocks. In the USCB, adsorbed methane predominates (>90\%). It is physically and chemically bound with the coal substance and accumulates in coal micropores (e.g. Honysz 2015, Kozłowski and Grębski 1982; Lamberson and Bustin, 1993). Free and adsorbed methane occur in mutual equilibrium expressed by gas pressure. The change in pressure caused by e.g. tectonic activity, mining exploration causes the release of gas from coal as a result of desorption or diffusion into mining excavations, posing a serious explosion or fire hazard (e.g. Kozłowski and Grębski, 1982; Kędzior and Dreger, 2019). The volume of adsorbed methane, in the same temperature and pressure conditions, depends on micropores and macropores content in coal. Kozłowski and Grębski (1982) showed that more microporous coals can accumulate more methane in the coal structure (Figs 5a; 5b). Studies carried out on coals from Western Canada (Lamberson and Bustin, 1993) revealed that vitrinite-rich coals have a greater sorption capacity than inertinite-rich colas in the same rank, however research from the 1970s (Harris and Yust, 1976) displayed that coal micropores are predominantly located in vitrinite, while in the inertinite, meso- and macropores.

Methane is an odourless, colourless, and tasteless gas, lighter than air, which displaces oxygen from the atmosphere making it non-breathable. Unfortunately, $\mathrm{CH}_{4}$ is a highly explosive gas when its concentration in the air reaches $5-15 \%$, but the strongest explosion occurs at $9.5 \%$ methane content. The factor causing ignition of the methane-air mixture is a temperature exceeding $650^{\circ} \mathrm{C}$, while the explosion temperature is $1500^{\circ} \mathrm{C}$ (Kozłowski and Grębski, 1982, Frączek 2005, Honysz 2015; Karacan et al., 2011, Dreger and Kędzior, 2019; Kędzior and Dreger, 2019).

As it has been already mentioned, methane has been accompanying coal-bearing formations since the beginning of the coalification processes. For this reason the methane hazard is one of the most dangerous natural hazards in underground coal mining industry. Methane content in Polish coal seams is measured in coal samples in hermetic containers by means of vacuum degasification. Polish health and safety regulations impose sampling for methane content measures at $200 \mathrm{~m}$ intervals in a drifted excavation. Coal samples are collected from boreholes drilled from mine side walls and from the surface. Based on the regulation of the Ministry of the Environment, four categories of methane hazard are specified in the Polish mining industry (Table 3) (Regulation of the Ministry of the Environment 2013).

Table 3 Methane hazard categories in Polish hard coal mining (Regulation of the Ministry of the Environment 2013 [29.01.2013]) 


\begin{tabular}{|ll|}
\hline Category & Methane content $\left(\mathrm{m}^{3} \mathrm{CH}_{4} / \mathrm{Mg}\right.$ coal $\left.{ }^{\text {daf }}\right)$ \\
\hline Methane-free & $<0.1$ \\
\hline I & $0.1-2.5$ \\
\hline II & $>2.5 \leq 4.5$ \\
III & $>4.5 \leq 8$ \\
IV & $>8$; or methane and rock outburst occurred \\
\hline
\end{tabular}

\subsection{Sources of methane emission and gas utilisation}

As it has been mentioned before, $\mathrm{CH}_{4}$ creates an explosive mixture with oxygen, that is why the mining air rich in methane is removed through ventilation systems outside the mine, or to a place in the ventilation network where it will no longer be dangerous (e.g. Coal Mine Methane Sources, Kozłowski and Grębski 1982). All of the methane emitted during mining activities is called Coal Mine Methane (CMM) (Karacan et al. 2011) which often occurs at three locations: the dog heading, the working faces, and the goafs. Generally, the CMM is liberated in three streams: degassing processes $\left(\mathrm{CH}_{4}\right.$ content $\left.60-95 \%\right)$, Ventilation Air Methane Emission (VAM) $\left(\mathrm{CH}_{4}\right.$ content 0.1-1\%), and CMM drained from goafs $\left(\mathrm{CH}_{4}\right.$ content 30-95\%) (Su et al., 2005; Ju et al. 2016). Methane utilisation is one of the most important ways of preventing natural hazards. The absolute methane emission can be described as the amount of emitted gas per minute $\left(\mathrm{m}^{3} / \mathrm{min}\right.$ ) or per annum (million $\mathrm{m}^{3} /$ year). To ensure mine safety, fresh air is circulated through underground coal mines using ventilation systems to dilute in-mine concentrations of methane (VAM emission) to levels well below explosive (Warmuziński 2008). These concentrations are regulated by mine safety authorities and regulations. Methane concentration in the ventilation air has to be under $0.75-1.0 \%$ to secure safe conditions (Regulation of the Ministry of the Environment 2013, Honysz 2015). Ventilation air emission is described as the volume of emitted gas per annum (million $\mathrm{m}^{3}$ /year). VAM together with mine air is discharged into the atmosphere by ventilation shafts. It is the largest source of methane emissions from mines, about 600 million $\mathrm{m}^{3}$ of methane is now emitted to the atmosphere annually from all mines in the USCB. The second, very desirable and often applied way to keep a working mine safe is degassing (methane drainage), which leads to the drainage of as much of the coal-bed gases as possible. The captured $\mathrm{CH}_{4}$ can be used in internal mining processes, sold to external customers or released to the atmosphere, enhancing thereby the greenhouse effect (Warmuziński 2008, Honysz 2015, Dreger and Kędzior 2019; Kędzior and Dreger 2019). Coal Bed Methane (CBM) is a gas almost entirely composed of $\mathrm{CH}_{4}(90-98 \%)$ captured from virgin (unmined) coal seams (e.g. Ju et al. 2016; Krause 2019). Large volumes of the CBM can be drained by vertical or horizontal boreholes before mining starts to ensure work under safer methane conditions in the future, when mining begins (Diamond 1994, Noack 1998). Methane can be captured also from coal-beds in working coal openings (CMM) or from abandoned coal workings and goafs (AMM) which can still produce significant methane emissions from diffuse vents or fissures (Coal Mine Methane Sources, Honysz 2015, Duda and Krzemień 2018). The methane emission does not stop with the coal mining closure processes. Investigations carried out in the abandoned Anna mine in Poland have revealed that $\mathrm{CH}_{4}$ emission can continue for up to 15 years following mine closure. In every year the trend is decreasing and the predictions showed a total of 7.9 million $\mathrm{m}^{3}$ of methane could be emitted into the mine goafs during the years 2017 - 2023 (Duda and Krzemień 2018). In 2018, of the total volume of methane emitted in the USCB amounting to 916 million $\mathrm{m}^{3}, 599$ million $\mathrm{m}^{3}$ was VAM and the remaining 317 million $\mathrm{m}^{3}$ was methane from the demethanation of excavations. Only 203 million $\mathrm{m}^{3}$ of methane was utilised, which is just over $22 \%$ of the total methane emissions in the USCB (Report, 1995-2019).

\section{Results And Discussion}

\subsection{Methane distribution}

Current spatial distribution of the methane content in the Upper Silesian Coal Basin depends inter alia on the thick and hermetic Miocene overburden (methane accumulation), lithological character of Carboniferous sediments, and tectonic dislocations (methane migration) (Section 4.1., Kozłowski and Grębski 1982; Kotas, 1994; Kędzior, 2009; Słoczyński and Drozd, 2018; Krause, 2019). In the Upper Silesian Coal Basin two main geological patterns of vertical distribution of coal-bed methane (CBM) were 
distinguished, (Kotas 1994, Kędzior 2009) (Fig. 6). Pattern A is associated with northern and central areas of the coal basin, characterised by the presence of naturally degassed coal seams down to the depth of $400-600 \mathrm{~m}$ or deeper in some areas. With depths greater than $500 \mathrm{~m}$, the $\mathrm{CH}_{4}$ content increases rapidly until it reaches the primary methane zone with methane content of up to $15 \mathrm{~m}^{3} / \mathrm{Mg}$ coal daf. Going deeper, methane content tends to decrease. The northern pattern (A) is related to the Budryk mine, which is located in the north-western part of the basin (Fig 1). Figure 6 illustrates the distribution of methane content in the Budryk coal seams (JCC internal report). The maximum $\mathrm{CH}_{4}$ concentrations in the seams refer to the northern pattern (A) of the methane vertical distribution. The natural degassed zone is evident to the depth of $600 \mathrm{~m}$, then methane content increases rapidly until the primary zone of methane content is reached. It is evident here, that thin and permeable Triassic and Miocene overburden is not sufficient to stop the migration of gases upwards (Table 4). The average and maximum $\mathrm{CH}_{4}$ concentrations in the Budryk seams tend to increase with depth, reaching maximum values of over 7 (average) and 15 (maximum) $\mathrm{m}^{3} / \mathrm{Mg}$ coal daf between -750 and -990 metres above sea level (between ca. 1000 and $1200 \mathrm{~m}$ below ground level). (Fig. 6). The depth range of the primary methane zone has not been exactly determined so far in the mine under study (Fig. 6).

Figure 3 shows the fault distribution in the Budryk mine field (402 coal seam). These dislocations form a dense network of faults with latitudinal (Barbara fault zone) and longitudinal (e.g. Knurów and Chudecki faults) orientation. The existing fault network probably aided the natural process of degassing the upper parts of the deposit in the geological past, and the faults themselves may today constitute the boundaries between the deposit parts with different level of gas saturation, and thus have different effects on the intensity of gas emissions to the mine workings of the Budryk mine. The role of faults in gas migration has also been stated elsewhere (Thielemann, 2001).

Pattern B is associated with the southern part of the basin and includes two distinct zones of methane content (Fig. 6). The first methane zone covers the secondary accumulation of $\mathrm{CH}_{4}$ adsorbed in coal seams and free gas accumulated immediately below the thick and impermeable Miocene cover (Fig. 6). The next methane zone, so called primary with increased concentrations of methane is separated by an interval of reduced $\mathrm{CH}_{4}$ content in coal seams (400-800 m below ground level, Fig. 6). The primary methane zone lies deeper (> $1000 \mathrm{~m}$ ), with the $\mathrm{CH}_{4}$ concentration of up to 10-16 $\mathrm{m}^{3} / \mathrm{Mg}$ coal daf (Kotas 1994, Kędzior 2012). This zone contains thermogenic methane produced as a result of the coalification process in the late Carboniferous (Kotarba, 2001). Increased methane content in the uppermost part of Carboniferous coal bearing series sealed with hermetic overburden is conditioned by the occurrence of microbial methane produced in the pre-Miocene period and then mixed with thermogenic methane (Kotarba and Pluta, 2009). The methane depth zones with faults in the area of the Pniówek mine are shown in Figure 4. The main dislocation of Bzie-Czechowice, which is a regional dislocation in the basin scale, is located in the south of the studied area and displaces the primary gas-bearing zone in the throw direction (to the south, Fig. 4). Together with the remaining faults (e.g. Krzyżowice I and II), they seem to be migration pathways for gas between the primary and secondary methane zones. Probably thanks to them, thermogenic methane migrated towards the Carboniferous top and supplied the secondary gas-bearing zone (Kędzior, 2009, 2012).

The pressure of gas accumulated just below the Miocene cover is higher in comparison to the remaining parts of the Carboniferous series and oscillates around 6- $7 \mathrm{MPa}$. After the Carboniferous period (especially in Mesozoic and Paleogene time), the top surface of coal bearing formations were exposed and subjected to weathered and erosion processes. To the present, in the topmost part of the Pniówek coal deposit, a layer of coal-bearing detritus with a high 20-30\% porosity has been preserved and now is sealed by the Miocene deposits. The currently observed zone of increased gas pressure is associated with porous coalbearing weathered deposits in the Carboniferous top (Janas 1962, Tarnowski 1989), which is a reservoir of both secondary microbial gas and migrating thermogenic methane (Kotarba and Pluta, 2009).

The differential vertical and horizontal methane distribution in coal basin caused by e.g. overburden occurrence, faulting and folding was identified in many coal basins (Noack 1998, Thielemann 2001, Ju et al. 2016). The Pniówek mine corresponds to the southern pattern of the $\mathrm{CH}_{4}$ vertical distribution (Fig. 6). In contrast to the Budryk mine, the thick and impermeable Miocene Skawina Formation (Table 4) has prevented gases release from coal seams to the atmosphere in the geological past. A comparative description of the Carboniferous series overburden in both described mines is presented in Table 4. 
Along the entire profile of the Pniówek coal deposit methane content fluctuates, thus seams with varied $\mathrm{CH}_{4}$ concentrations from 0.003 to more than $16 \mathrm{~m}^{3} / \mathrm{Mg}$ coal daf were found. However, all production levels which are now operated have been assigned to categories III and IV of methane hazard, due to the vast majority of measurements $>4.5 \mathrm{~m}^{3} / \mathrm{Mg}$ coal daf. (JCC internal report). The most intense methane inflow to coal workings is when tensions and pressures change. The stress relaxation and pressure decrease in coal seams takes place when a new seam starts to be mined. Under these conditions the largest volumes of $\mathrm{CH}_{4}$ are emitted to the mine excavations, aggravating the hazard (Frączek 2005).

Table 4 Overburden composition in the Budryk and Pniówek mining areas (Kotas 1982; Buła and Kotas 1994; JCC internal report)

\begin{tabular}{|c|c|c|}
\hline & Budryk mine & Pniówek mine \\
\hline Overburden & Quaternary, Neogene, Triassic & Quaternary, Neogene \\
\hline Thickness & $0-180 m$ & $220-1000 \mathrm{~m}$ \\
\hline \multicolumn{3}{|l|}{ Quaternary } \\
\hline Thickness & $0-79 \mathrm{~m}$ & $6-80 m$ \\
\hline $\begin{array}{l}\text { Composition } \\
\text { (lithology) }\end{array}$ & Sands, Clays, Gravels & Clays, Sands, Gravels \\
\hline Description & $\begin{array}{l}\text { Pleistocene glacier-water accumulation. Reduction in thickness in the S } \\
\text { part of the coal deposit. In the SW part of the area deposits rest directly } \\
\text { on the Carboniferous layer. }\end{array}$ & $\begin{array}{l}\text { Holocene alluvial and Pleistocene } \\
\text { glacier-water and glacier } \\
\text { accumulation }\end{array}$ \\
\hline \multicolumn{3}{|c|}{ Neogene (Miocene) } \\
\hline Thickness & $<134.8 \mathrm{~m}$ & $150-900 m$ \\
\hline $\begin{array}{l}\text { Composition } \\
\text { (lithology) }\end{array}$ & Clay, marl clay, marls, claystones, sand clays, sands, and sandstones & $\begin{array}{l}\text { Marl, clay, sands, tuffites, } \\
\text { sandstones, conglomerates }\end{array}$ \\
\hline Description & $\begin{array}{l}\text { Sediments found in the N, NE, W part of the mining area. Deposits lying } \\
\text { on the weathered Carboniferous sediments and covered by Quaternary } \\
\text { layers. }\end{array}$ & $\begin{array}{l}\text { Thickness is variable, with the } \\
\text { thickest sediments in SE and the } \\
\text { thinnest in N and W. }\end{array}$ \\
\hline \multicolumn{3}{|l|}{ Triassic } \\
\hline Thickness & $<65.8 \mathrm{~m}$ & - \\
\hline Composition & Clay and limestones marls, sandstones & - \\
\hline Other & $\begin{array}{l}\text { Sediments deposited directly on the Carboniferous layers. The biggest } \\
\text { spread of sediments is found in the E part of the area. }\end{array}$ & - \\
\hline
\end{tabular}

The gas (methane) pressure in the coal seam is determined by the methane content in coal (Tarnowski 1971, 1989). The gas pressure is defined by the desorption intensity index method used commonly in the Polish and worldwide mining industry (Kozłowski and Grębski 1982; Wierzbicki and Skoczylas 2014, Krause 2019) to classify the methane danger, before the more accurate tests will be carried out by the certified mining laboratories. The collected data of the gas pressure, in the southern part of the Upper Silesian Coal Basin by Tarnowski (1971) revealed that methane content in the coal seam is fairly correlated with the methane pressure/desorption intensity(Fig. 7). The recent results of tests made by the CLP-B Mining Laboratory in JastrzębieZdrój (Poland) for the Budryk and Pniówek mines for the years 2018-2020 showed similar outcomes describing the methane content and gas desorption/pressure interdependence (Figs 8a and 8b).

\subsection{Coal mining}

Hard coal extraction in Polish underground mining is deeper about 8 metres per year on average. As a result, coal production takes place in coal seams of variable gas and physico-chemical conditions. In most mines in the USCB methane content increases with increasing depth (Krause 2019). As the depth of extraction increases, gas permeability in coal seams decreases and pre-mining methane drainage is not sufficient, therefore the methane hazard increases. The average depth of coal extraction in 2010 was 
around 700 metres, and from year to year it was permanently increasing by 8-10 metres. Now, the average depth of coal production is 788 meters and coal sorption capacity is much lower than in shallower seams and the gas pressure in coal seams increases with depth (Report 1995-2019, Krause 2019). Most of the methane emitted to the coal workings comes from depleted, overlying and underlying coal seams (60\%), the remainder of $\mathrm{CH}_{4}$ is emitted from extracting longwall (40\%) (Krause 2019).

Another important factor is the concentration of coal production. Hard coal in the USCB is almost exclusively produced by means of longwall systems with the use of heading machines and longwall mechanical coal miners. Longwall length and height, daily extraction progress are the main variables needed to determine the coal output concentration. The longwall length increased by $40.9 \%$ in recent years, coal production concentration rose and absolute methane emission also increased (Turek 2007). As longwall length increases, the area of exploitation relaxation rises and the volume of released and migrated methane is also higher. The technical and operating parameters are one of the important features which describe coal deposit exploitation. In the Budryk mine, the number of operating walls has been changing during the studied period of coal production (1994 - 2018). The least number of operating walls (only 2) was observed in 1994, 1995, 1998 and 2009. On the other hand, in 2005 coal was produced in seven walls which was the highest number throughout the study history. The longwall length varied from 140 to 270 metres, but the most common length was 250 metres. Hard coal production at production levels becoming deeper every year does not change the technical parameters of extracting walls. No significant concentration of coal extraction was found, as the parameters of longwalls change regardless of the year, depth and amount of coal extracted. The wall advance length varied from around 500 to over 1400 - 1500 metres. The average longwall height between 1994 and 1998 was under 2 metres (Table 5). In 1999 the height was 2 metres, but in succeeding years it was more than 2 metres, but it did not exceed 3 metres (on average).

During the last 4 years of the study, the average depth of coal production in the Pniówek mine rose from -613 (2015) to -665 metres above sea level in 2018 (about 880 in 2015 to 930 meters below ground level in 2018) which was 13 metres deeper every year. Between 2015 and 2018 a greater concentration of coal production was observed. The longwall advance in the Pniówek mine, was gradually increasing from around 56 metres in 2015-2016 to 78 metres (per year) in 2017. During the last year of the study, the longwall progress slightly slowed down to 62 metres. In this four-year period only six longwalls were operated. (JCC internal report).

Table 5 Number and average height of mine longwalls in the Budryk Mine 


\begin{tabular}{|lll|}
\hline Year & Number of operating longwalls & Average longwall height \\
\hline 1994 & 2 & 1.7 \\
\hline 1995 & 2 & 1.7 \\
\hline 1996 & 4 & 1.7 \\
\hline 1997 & 4 & 1.6 \\
\hline 1998 & 2 & 1.4 \\
\hline 1999 & 4 & 2 \\
\hline 2000 & 4 & 2.9 \\
\hline 2001 & 4 & 2.5 \\
\hline 2002 & 3 & 3 \\
\hline 2003 & 3 & 2.5 \\
\hline 2004 & 3 & 2.8 \\
\hline 2005 & 7 & 3 \\
\hline 2006 & 3 & 2.5 \\
\hline 2007 & 3 & 2.6 \\
\hline 2008 & 5 & 2.7 \\
\hline 2009 & 2 & 2.3 \\
\hline 2010 & 4 & 2.3 \\
\hline 2011 & 4 & 2.7 \\
\hline 2012 & 5 & 2.5 \\
\hline 2013 & 3 & 2.1 \\
\hline 2014 & 4 & 2.2 \\
\hline 2015 & 4 & 2.4 \\
\hline 2016 & 4 & 2.2 \\
\hline 2017 & 3 & 2.4 \\
\hline
\end{tabular}

\section{Coal output in the Budryk and Pniówek mines}

The most important economic factor in every mine is the annual coal production. Economic possibilities, natural hazards, technical difficulties and market size affect the annual coal output of each mine (Dreger 2019,2020; Dreger and Kędzior 2019). Changes in coal production over time in both analysed mines are illustrated in Fig. 9. The Budryk mine started production in 1994, while the production data from Pniówek starts from 1986. In 1994, the Budryk mine was getting started with just 580 thousand $\mathrm{Mg}$ of extracted coal (Fig. 9). Over the following years coal production in Budryk was gradually increasing, reaching the highest production level in 2007 with 3.85 million $\mathrm{Mg}$ of extracted coal. In subsequent years, until the end of the study period, coal output dropped and retained a constant level of under 3 million $\mathrm{Mg}$ per year. On the other hand, the highest hard coal output in Pniówek was reported at the beginning of the research period, in the late 1980s, with the coal production exceeding $3.8 \mathrm{million}$ Mg. In the years 1991-1995 hard coal output dropped to 3.15 million Mg on average. In subsequent years (1997-2007) coal extraction was increasing, with a stable output of over 3.5 million Mg. After 2007, the coal output in Pniówek, similarly to Budryk, suddenly 
collapsed, reaching a minimum in Pniówek in 2012: only 2.57 million Mg of coal was produced. Fortunately, in the period 20152018 , a recovery in coal output was observed, with over 3 million of extracted coal annually.

\subsection{Methane emissions}

\section{Budryk Mine}

The absolute methane emission from all the coal excavations of the Budryk mine was measured in the period from 1994 to 2018. From the beginning of the study to the year 2005, the total methane emission rose from 2.21 to $55.80 \mathrm{million}^{3} /$ year (Fig. 10). In subsequent years (2006-2012) methane emission was around 40 million $\mathrm{m}^{3}$ of gas per year. From 2013 a large increase in methane emission was observed; in the last three years of the study (2016-2018) over 140 million $\mathrm{m}^{3}$ of $\mathrm{CH}_{4}$ was emitted yearly, which was three times more than the average emission in 1994-2012.

At the beginning, coal was mined at shallower, naturally degassed seams but when coal mining entered into a deeper zone with higher methane concentration, the total $\mathrm{CH}_{4}$ emission increased rapidly. The methane content and gas pressure increase with depth within the Main Trough area, including the Budryk mine, what is the main reasons of the large increase in methane emission at greater depths in the mine. The related data, such as degassing, ventilation air methane (VAM emission), and specific methane emission follow the trend of the absolute methane emission. The Budryk mine started degassing of the coal seams in the fourth year after coal extraction had been started (in 1997) (Fig. 10). Before that time, all of the methane was released directly to air. It is worth mentioning that from 1997 to 2013 between 30 and 50\% of all of the emitted methane was captured by the underground methane drainage system. When the total methane emission suddenly rose in the last five years of the research period, the share of degassing and utilising methane in internal mining processes also increased, to reach $70-88 \%$ in the period $2014-2018$. The specific methane emission describes how many $\mathrm{m}^{3}$ of gas are liberated to coal workings with single $\mathrm{Mg}$ of extracted coal. In contrast to the total methane emission, it shows the real methane hazard that miners and mining authorities have to deal with. From the beginning of the research period to 1998 the specific methane emission was below $10 \mathrm{~m}^{3} / \mathrm{Mg}$ of extracted coal. From 1999 until 2013 the amount of emitted gas was oscillating between 10 and $20 \mathrm{~m}^{3}$ of $\mathrm{CH}_{4}$ (Fig. 11). A large increase in the specific emission related to degassing and total $\mathrm{CH}_{4}$ emission took place in the period 2013-2014. In the last five years of the study the specific methane emission increased to $26 \mathrm{~m}^{3} / \mathrm{Mg}$ and was doubled (54-59 $\mathrm{m}^{3} / \mathrm{Mg}$ ) in 2016-2018. It is clearly visible that after 2013-2014 methane emission and gas-related hazards rapidly increased, but fortunately degassing and VAM emissions also increased, making coal extraction still very dangerous, but yet as safe as possible.

\section{Pniówek Mine}

The Pniówek coal mine has been producing coal much longer than Budryk, hence all the data come from the period 1986-2018. When we take a look at the total absolute methane emission and the related emission data, we will see that those trends are completely different than in the Budryk mine. The largest total $\mathrm{CH}_{4}$ emission values were observed in the late 1980 s and at the early 1990s, when the coal was mining just below the sealed Miocene strata, where methane was accumulated in the coal seams as well as in porous rock strata in the geological past, forming the local methane maximum associated with the pattern B of the USCB vertical $\mathrm{CH}_{4}$ distribution (Fig. 3). The largest absolute methane emission was reported in the period 1987-1989, when over 180 million $\mathrm{m}^{3}$ of gas was released to mine excavations over a one year period (Fig. 12). In subsequent years the emission was decreasing from over 167 million $\mathrm{m}^{3}$ in 1990/91 to the average of 123 million $\mathrm{m}^{3}$ yearly during the next 26 years' period (19922017). In that period the emission was fluctuating with periodic increases and decreases. The lowest total $\mathrm{CH}_{4}$ emission, and the

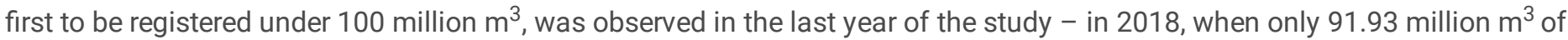
methane was emitted. It is the lowest emission observed in the study history in Pniówek, but the total methane emission in this mine was the largest in the entire USCB in the last 20-25 years. Only the Budryk mine exceeds Pniówek's total $\mathrm{CH}_{4}$ emission in the last years between 2015 and 2018 (Dreger 2019, Kędzior and Dreger 2019, Report 1995-2019). The VAM adopts a similar trend as the absolute $\mathrm{CH}_{4}$ emission, reaching maximum values from the beginning of the research to 1991, with the highest value in 1989, when over 109 million $\mathrm{m}^{3}$ of this dangerous gas was discharged out of the mine (Fig. 12). Over subsequent years the VAM emission trend is stable with small rises and decreases, reaching the lowest value similar to that of the absolute $\mathrm{CH}_{4}$ emission in 
2018 , when only 60 million $\mathrm{m}^{3}$ of gas was removed by the ventilation systems out of the mine. The lowest fluctuations in the 33 years' study period were noticed in the specific methane emission. The average amount of emitted methane with single Mg of coal was $39.5 \mathrm{~m}^{3}$, with the highest value observed in $1991\left(51.4 \mathrm{~m}^{3} / \mathrm{Mg}\right.$ ) (Fig. 13). Between 1991 and 2008 we can observe a decrease in specific methane emission with over $30 \mathrm{~m}^{3}$ of methane emitted per one $\mathrm{Mg}$ of coal. In $2008-2014$ the $\mathrm{CH}_{4}$ emission over $40 \mathrm{~m}^{3} / \mathrm{Mg}$ was noticed with slight, but constant decrease in the following years until the end of the study period when the lowest emission was recorded: $25.51 \mathrm{~m}^{3}$ of $\mathrm{CH}_{4} / \mathrm{Mg}$ in 2018. In the period 2015 - 2018 coal production increased to over 3 million $\mathrm{Mg} /$ year and the total methane emission decreased to under 120 million $\mathrm{m}^{3} /$ year. As a result, the specific $\mathrm{CH}_{4}$ emission decreased and if the output and emission trend remain, the specific $\mathrm{CH}_{4}$ emission will be under $30-40 \mathrm{~m}^{3}$ of $\mathrm{CH}_{4} / \mathrm{Mg}_{\mathrm{g}}$ ooal annually. Due to complex and diversified faulting (Figs 3 and 4), geological structure and deeper coal extraction every year, the methane emission fluctuates in both mines with consistent trends. In the Budryk mine the trend is increasing but in the Pniówek mine it is slightly, but constantly decreasing. Despite the different methane liberation trends, the total $\mathrm{CH}_{4}$ emission in both mines remains at the highest level in the Upper Silesian Coal Basin throughout the entire research period (Table 6.)

In addition to methane emissions in the Pniówek mine, much more dynamic events took place in the form of gas and rock outbursts. In 2002, during the blasting operations at the level of $1000 \mathrm{~m}$, there was an outburst of approx. $250 \mathrm{~m}^{3}$ of grinded down coal and ejection of $\sim 55,000 \mathrm{~m}^{3}$ of methane. The concentration of released methane in the mine air increased to $~ 86 \%$.

The gas and rock outburst in the neighbouring Zofiówka mine in 2005, which took 3 fatalities, resulted from the accumulation of methane in the mylonitic coal accompanying the two fault zones (Jakubów et al., in: Kędzior, 2012) (see Section 4.1.)

Table 6 The most methane-gassy mines in the Upper Silesian Coal Basin -absolute methane emission [million $\mathrm{m}^{3} \mathrm{CH}_{4} / \mathrm{year}$ ] $(\mathrm{JCC}$ internal report; Report 1995-2019) 


\begin{tabular}{|c|c|c|c|c|c|c|c|c|c|c|}
\hline $\begin{array}{l}\text { Year } \\
\text { / Mine }\end{array}$ & Budryk & Pniówek & Brzeszcze & Krupiński & B-Z-J* & Silesia & Marcel & $\begin{array}{l}\text { Knurów- } \\
\text { Szczygłowice }\end{array}$ & $\begin{array}{l}\text { Murcki- } \\
\text { Staszic }\end{array}$ & $\begin{array}{l}\text { Mystowice } \\
\text { - Wesoła }\end{array}$ \\
\hline 1994 & 2.21 & 116.46 & 123.38 & 45.58 & 89.57 & 40.73 & 11.13 & 2.98 & 17.77 & 55.65 \\
\hline 1995 & 2.21 & 112.83 & 116.53 & 48.18 & 119.17 & 42.87 & 11.21 & 6.62 & 20.75 & 48.39 \\
\hline 1996 & 5.19 & 116.03 & 135.76 & 45.55 & 117.96 & 41.68 & 39.47 & 8.92 & 18.48 & 54.69 \\
\hline 1997 & 19.60 & 130.56 & 124.80 & 37.58 & 113.62 & 35.17 & 40.22 & 8.8 & 28,81 & 57.63 \\
\hline 1998 & 21.11 & 126.04 & 107.69 & 39.79 & 111.80 & 38.91 & 10.09 & 3.6 & 32.22 & 56.63 \\
\hline 1999 & 37.18 & 122.35 & 98.09 & 31.44 & 107.01 & 35.77 & 49.54 & 8.97 & 26.16 & 56.77 \\
\hline 2000 & 49.55 & 125.28 & 101.46 & 30.69 & 99.69 & 34.58 & 36.05 & 15.51 & 20.39 & 53.57 \\
\hline 2001 & 41.95 & 114.32 & 113.12 & 42.22 & 94.44 & 34.61 & 26.91 & 28.18 & 27.32 & 51.21 \\
\hline 2002 & 52.56 & 114.82 & 111.37 & 40.24 & 87.26 & 33.28 & 23 & 16.74 & 25.19 & 57.10 \\
\hline 2003 & 45.88 & 125.60 & 104.95 & 59.29 & 88.56 & 32.63 & 24.19 & 21.44 & 19.02 & 56.04 \\
\hline 2004 & 46.54 & 135.92 & 101.28 & 58.53 & 99.45 & 31.83 & 14.68 & 27.2 & 31.50 & 44.76 \\
\hline 2005 & 55.80 & 133.96 & 98.78 & 67.13 & 124.55 & 30.34 & 15.33 & 33.35 & 19.67 & 45.84 \\
\hline 2006 & 43.58 & 128.47 & 102.14 & 65.42 & 124.55 & 32.26 & 15.33 & 55.6 & 24.97 & 45.84 \\
\hline 2007 & 39.00 & 134.84 & 102.91 & 62.74 & 123.60 & 31.61 & 16.12 & 83.58 & 34.07 & 55.42 \\
\hline 2008 & 45.32 & 128.44 & 104.88 & 99.70 & 112.90 & 32.22 & 15.8 & 51.1 & 40.60 & 49.90 \\
\hline 2009 & 44.82 & 122.99 & 110.74 & 78.25 & 95.11 & 34.2 & 17.37 & 52.79 & 33.78 & 59.20 \\
\hline 2010 & 41.62 & 117.30 & 116.53 & 81.63 & 97.19 & 22.5 & 20.8 & 45.94 & 32.30 & 57.17 \\
\hline 2011 & 46.75 & 125.14 & 112.54 & 68.25 & 91.34 & 13.47 & 21.68 & 49.74 & 40.24 & 55.66 \\
\hline 2012 & 37.05 & 116.88 & 104.08 & 54.24 & 95.10 & 18.51 & 24.79 & 63.8 & 39.31 & 61.22 \\
\hline 2013 & 57.01 & 119.39 & 92.96 & 80.09 & 85.59 & 21.58 & 23.18 & 44.13 & 59.16 & 55.77 \\
\hline 2014 & 69.93 & 122.09 & 94.88 & 67.83 & 80.64 & 35.98 & 22.47 & 34.29 & 55.11 & 68.99 \\
\hline 2015 & 88.27 & 119.89 & 75.61 & 75.09 & 92.13 & 41.97 & 22.67 & 46.11 & 70.93 & 78.34 \\
\hline 2016 & 146.42 & 104.32 & 86.88 & 74.94 & 99.97 & 38.1 & 20.73 & 57.64 & 45.14 & 83.56 \\
\hline 2017 & 142.36 & 114.82 & 109.56 & 57.17 & 93.60 & 41.08 & 21.05 & 78.51 & 48.37 & 68.68 \\
\hline 2018 & 155.23 & 91.93 & 110.48 & 19.75 & 90.22 & 30.8 & 20.46 & 59.59 & 43.56 & 70.56 \\
\hline
\end{tabular}

* B-Z-J represents 3 separate mines (Borynia, Zofiówka, Jastrzębie) merged within one large coal mining enterprise

\section{Factors Influencing The Methane Emissions In The Studied Mines}

The Pniówek and Budryk mines are ones of the most methane-gassy collieries in the Upper Silesian Coal Basin, extracting coal under the III and IV categories of methane hazard. The variations of methane emissions in these mines are different and have other geological and mining origins. The Budryk mine, as the youngest working coal mine in Poland, started coal extraction in 1994. In the geological past, shallow lying coal seams (up to about 500-600 m deep) were naturally degassed, owing to erosion and hydrodynamic changes in the rock mass in the northern part of the USCB before the Miocene period. The degassing process was facilitated by faults constituting migration pathways for methane. As a result, methane emission values correspond to the pattern A of the vertical methane distribution in the USCB. Shallower seams were emitting less than 40 million $\mathrm{m}^{3}$ of $\mathrm{CH}_{4}$ yearly during mining activities. As the depth of extraction increased, entering the primary methane maximum at the depth of 600 metres 
(Fig. 6), the $\mathrm{CH}_{4}$ emission to mine excavations increased rapidly, exceeding 140 million $\mathrm{m}^{3}$ of gas in the last three years of the study (2016-2018). The increase in methane content in coal seams and surrounding rocks results in an increase in gas pressure in the rock mass (Figs 7, 8a and 8b), which also affects the intensity of methane emission into mine workings. Budryk, as the deepest mine in Poland, producing coal at $1290 \mathrm{~m}$ below the surface, where the average methane content amounts to about 6 $\mathrm{m}^{3} / \mathrm{Mg}$ coal daf, and maximum reaches $10-12 \mathrm{~m}^{3} / \mathrm{Mg}$ coal daf, struggles with very tough methane conditions. Methane is also liberated to the coal workings from under- and overlying coal seams, as well as from abandoned excavations and from goafs. No significant concentration of coal extraction was found, as the parameters of longwalls change regardless of the year, depth and amount of coal extracted. The highest methane hazard seems to be connected with coal extraction from the deep, methane-rich seams and from $\mathrm{CH}_{4}$ migrating from over- and underlying levels. The intensity of methane liberation from the coal surface, over and undermined seams and from mined coal to the coal workings increases as the methane concentration in coal increases too (Kozłowski 1982, 1986; Krause 2019). In the higher methane content seams, the $\mathrm{CH}_{4}$ emission from the $1 \mathrm{~m}^{2}$ of the coal surface rises rapidly, making the mining works more dangerous in every growth of the methane content (Fig. 14). The increasing rate of the daily hard coal output results in the greater volumes of emitted methane during the extraction. In the lower categories of methane hazard (I-III) the increase in emission with bigger extraction is not so evident than in the fourth category of methane hazard ( $>8 \mathrm{~m}^{3} \mathrm{CH}_{4} / \mathrm{Mg}$ coal daf) when the absolute methane emission increases rapidly with greater mining progress (Myszor 1976).

The real methane hazard is indicated by the specific methane emission. The volume of emitted gas $\left(\mathrm{CH}_{4}\right)$ per one extracted $\mathrm{Mg}$ of coal during the last three years of the study correspond to the amount of total methane emission. Coal production was on a similar level, but $\mathrm{CH}_{4}$ emission increased rapidly, exceeding $50 \mathrm{~m}^{3} \mathrm{CH}_{4} / \mathrm{Mg}$ in the 2016-2018 period. This value significantly exceeds the measured methane content of the coal seam. This means, as mentioned before, that methane emissions do not only come from the seams currently being extracted, but also from the overlying and underlying seams, as well as surrounding rocks and old goafs (e.g. Karacan et al., 2011; Kędzior and Dreger, 2019). The vertical distribution of methane content observed in the Pniówek mine is different from that in the Budryk mine. The difference concerns the occurrence of the zone secondarily saturated with methane under the Carboniferous top, which is evident by the high gas content in coal seams lying in this zone. The zone of increased pressure of free gas (7-8 MPa) associated with porous detritus lying at the uppermost part of the Carboniferous sediments is also important (see Section 5.1). Thus, coal extraction at the beginning of the study, when shallower seams were operated, was conducted under a higher methane hazard than when it was carried out in deeper seams in subsequent years. The secondary methane accumulation with methane content exceeding $10 \mathrm{~m}^{3} / \mathrm{Mg}$ coal daf placed under the Miocene cover and also the occurrence of many faults (Fig. 4, see Section 5.1), considered as migration pathways for methane, were the cause of the high methane emission (over 160 million $\mathrm{m}^{3} \mathrm{CH}_{4}$ ) to coal workings in a year period. In subsequent years, the total methane emission dropped to over 90 million $\mathrm{m}^{3}$ in 2018 , which may be associated with a decrease in the methane content of the seams as the depth of extraction increased and as it entered the zone of reduced gas content and pressure. The deeper occurring primary gasbearing zone has a lower methane content $\left(<10 \mathrm{~m}^{3} / \mathrm{Mg}\right.$ coal daf) than in the case of the secondary methane zone adjacent to the Miocene overburden (about $10 \mathrm{~m}^{3} / \mathrm{Mg}$ coal daf) (Fig. 6). The specific methane emission was over $40 \mathrm{~m}^{3} \mathrm{CH}_{4} / \mathrm{Mg}^{\text {in }}$ the periods 1986 - 1992 and 2008 - 2014. Between these periods (1993 - 2007) the decrease in methane liberation with every single Mg of coal was noticed - down to $30-39 \mathrm{~m}^{3} \mathrm{CH}_{4} / \mathrm{Mg}$ per year. During the last years of the study $(2015-2018)$ the overall coal output increased while the total methane emission decreased, thus the specific $\mathrm{CH}_{4}$ emission dropped to $25.51 \mathrm{~m}^{3} \mathrm{CH}_{4} / \mathrm{Mg}$ in the last year of the study, and this trend should continue in the forthcoming years. First of all, due to the varied spatial distribution of gas content in coal seams, which is related to the different geological structure of both researched coal deposits, $\mathrm{CH}_{4}$ emission was diversified in the two studied mines, but still the highest in the Upper Silesian Coal Basin. Most of the methane emitted to coal workings comes from adjacent extracted-out overlying and underlying coal seams $(60 \%)$, the rest of $\mathrm{CH}_{4}$ is emitted from the operated longwall (40\%). The concentration of coal production in the Pniówek mine is evident due to greater longwall advance every year with the same number of operating longwalls (6). The increasing wall advance is favourable for methane emission directly from the operated longwall during the whole period of production. In coming years the depth of production will need to be greater, coal extraction concentration and walls lengths will also increase. Methane will flow into the coal workings from extractedout coal seams through rock fractures and faults aggravating the methane hazard. Methane drainage and VAM emission need to 
remain at a high level to keep the underground extraction as safe as possible when coal mining will be performed at the highest (IV) category of $\mathrm{CH}_{4}$ hazard.

To sum up, methane emissions in the studied mines are the result of natural factors (geological and gas content of the rock mass), influencing in the first place, and anthropogenic (mining) aspects acting additionally. Details are shown in the Table 7.

Table 7 Summarized division of the factors influencing the methane emissions in the Budryk and Pniówek Mines.

Factors influencing the methane emissions

$\begin{array}{ll}\begin{array}{l}\text { Group of } \\ \text { factors }\end{array} & \text { Budryk Minéwek Mine }\end{array}$

Natural Geological - thin and permeable overburden of (acting in the coal-bearing strata, deep reaching natural first place) degassed zone

Faults distribution, dislocations probably aided the degassing process of the upper parts of the deposit

Gas content and pressure increasing with depth
Geological - thick and impermeable (sealing) Miocene overburden

Secondary zone of increased methane content and elevated gas pressure placed in the uppermost part of the Carboniferous strata

The occurrence of the primary and secondary zones of gas content and pressure in depth profile of coal bearing sediments

Fault tectonics, faults considered as migration pathways for methane and often responsible for gas and rocks outbursts
Mining (additionally acting)

\section{Concentration of coal output}

Wall length, height and advance increase

Methane emissions from now operating longwalls, underlying and overlying coal seams, as well as abandoned workings and goafs

Depth of coal extraction

\section{Conclusions}

The Budryk and Pniówek Mines belong to the most gassy mines in the Upper Silesian Coal Basin. However, both are located in different parts of the basin, which are characterised by both different geological structure and spatial distribution of gas content. At the Budryk mine, the youngest in the basin, coal mining was initially carried out (1990s) in a shallow naturally degassed zone,

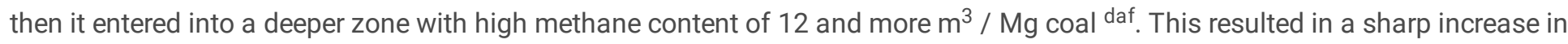
methane emissions from around 2 to over 55 million $\mathrm{m}^{3}$ of methane per year (late 2010s).

At the Pniówek mine, coal was initially mined in high-methane seams occurring in the secondary methane-bearing zone with high methane content in coal seams ( $>10 \mathrm{~m}^{3} / \mathrm{Mg}$ coal daf) and elevated free gas pressure (7-8 MPa) in weathered rocks, located just below the sealing Miocene overburden. This resulted in record-high methane emissions in the initial extraction period (1980s), reaching 180 million $\mathrm{m}^{3}$ annually. In subsequent years, methane emissions decreased to around 100 million $\mathrm{m}^{3}$ in 2018 with numerous fluctuations throughout the entire research period. This can be explained by the lower methane content and gas pressure in coal seams at a greater depths associated with the occurrence of a reduced methane content zone and the primary gas bearing zone occurring deeper, but with a lower gas content than the shallow, secondary one. Thus, it may seem that the vertical zonation of the gas content in seams is the main factor that controls methane emissions in the analysed mines, because the temporal variability of methane emissions coincides with the depth of coal extraction corresponding to individual gas zones.

Faults, breaks and rock discontinuities are an important factor of methane migration, because in their vicinity a decrease or increase in gas content and gas pressure has been observed. Often, methane had migrated through faults in the geological past, and thus fault zones can also be now a source of methane emissions into mine workings. In special circumstances, they can also cause more dynamic phenomena, such as gas and rock outbursts, which took place in the Pniówek and Zofiówka mines. 
Also important are the mining factors affecting methane emissions, such as the concentration of coal mining, the size of the mining longwalls, their number and the presence of goafs, which are an important source of methane emissions. Along with significant methane emissions in both mines, methane is captured by methane removal stations (which accounts for about half of the total methane emissions), which has a positive impact on safety of miners at work, economic balance of the mines and environmental protection (reduction of greenhouse methane emissions to the atmosphere).

\section{Declarations}

The authors declare that they have no conflict of interest.

All experiments which were done during research comply with the current law of the Republic of Poland.

Funding: This study was undertaken in the framework of the activities of the University of Silesia in Katowice and was funded by the University of Silesia, Institute of Earth Sciences (WNP/INOZ/2020_ZB32)

Acknowledgments This study was undertaken in the framework of the activities of the University of Silesia in Katowice and was funded by the University of Silesia, Institute of Earth Sciences (WNP/INOZ/2020_ZB32). The authors are grateful to the employees of Central Mining Institute in Katowice, employees of the CLP-B Mining Laboratory in Jastrzębie-Zdrój and employees of Budryk mine, especially to Mr. Dariusz Kluczniok, Adam Kurpas, Jacek Kurpan and from Pniówek mine to Mr. Zenon Fojcik and Paweł Faryniarz for their kind cooperation and leads during data collection for this research.

\section{References}

Buła Z, Kotas A, (1994) Geological atlas of the Upper Silesian Coal Basin. Part III Structural Geological Maps. Polish Geological Institute, Warsaw (in Polish)

Coal Mine Methane Sources- Coalbed Methane Outreach Program, Coal Mine Methane Sources https://www.epa.gov/cmop/coalmine-methane-sources available 23.11.2019

Diamond, WP (1994) Methane control for underground coal mines. Information Circular No. 9395. US Dept. of Interior, US Bureau of Mines, Pittsburgh, PA.

Dreger M (2019) Methane emission in selected hard-coal mines of the Upper Silesian Coal Basin in 1997-2016. Geology,

Geophysics \& Environment, vol 45(2): 121-132

Dreger M (2020) Changes in the methane emissions and hard coal output in the Brzeszcze mine(the Upper Silesian Coal Basin, Poland). Geology, Geophysics \& Environment, vol. 46 (2): 159- 174

Dreger M, Kędzior S (2019) Methane emissions and demethanation of coal mines in the Upper Silesian Coal Basin between 1997 and 2016 Environmental \& Socio-economic Studies, 7, 1:12-23

Duda A, Krzemień A (2018) Forecast of methane emission from closed underground coal mines exploited by longwall mining - a case study of Anna coal mine. J. Sust.

Min. 17, 184-194.

Gawlik L, Grzybek I (2002) Methane emission evaluation from the Polish coal basins

(hard coal mining). In: Studia Rozprawy Monografie. vol. 106 Instytut Gospodarki

Surowcami Mineralnymi i Energią PAN, Krakow (PL ISSN 0860-74-19 (in Polish with

English abstract).

Page 19/52 
JCC - Geological documentations and materials from Budryk and Pniówek coal mines, 2017 (unpublished)

Frączek R (2005) Methane hazard treatments in the hard coal mines. Zwalczanie zagrożenia metanowego w kopalniach węgla kamiennego. Publ. of Silesian University of Science and Technology, Gliwice (in Polish)

Gabzdyl W,Gorol M (2008) Geology and mineral resources in the Upper Silesia region and adjacent areas. Geologia i bogactwa mineralne Górnego Śląska i obszarów przyległych, Publ. of Silesian University of Science and Technology, Gliwice (in Polish)

Geršlová E, Goldbach M, Geršl M, Skupien P (2016)Heat flow evolution, subsidence and erosion in Upper Silesian Coal Basin, Czech Republic. International Journal of Coal Geology 154-155, 30-42.

Ghosh A, Patra P.K, Ishijima K et al (2015) Variations in global methane sources and sinks during 1910-2010. Atmos. Chem. Phys. 15 (5), 2595-2612.

Harris LA, Yust CS (1976) Transmission electron microscope observations of porosity in coal. Fuel 55, $233-236$.

Harvey C (2020) Methane Emissions from Oil and Gas May Be Significantly Underestimated

Estimates of methane coming from natural sources have been too high, shifting the burden to human activities [in] https://www.scientificamerican.com/article/methane-emissions- from-oil-and-gas-may-be-significantly-underestimated/ available April 2020

Heckel PH (2004) Newsletter of Carboniferous Stratigraphy 2004 - Chairman's column 1-3.

Hunt JM (1979) Petroleum Geochemistry and Geology, Geological Magazine,117(4)

Hunt JM (1991) Generation from gas and oil from coal and other terrestrial organic matter. Org. Geochem. 17(6), 673-680.

Honysz J (2015) Coal mining, part 2. Górnictwo 2Publ. Śląsk, Katowice (in Polish)

Janas J (1962) K nekterym problemum plynodajnosti OKR. Sbornik referatu ke konferenci o vetrani, klimatizaci w OKR. Rożnov pod Radhostem.

Ju Y, Sun Y, Sa Z, Pan J, Wang J, Hou Q, Li Q (2016) A new approach to estimate fugitive methane emissions from coal mining in China, Science of the Total Environment 543 (2016) 514-523

Karacan CÖ, Ruiz FA, Cotè M, Phipps S (2011) Coal mine methane: A review of

capture and utilization practices with benefits to mining safety and to greenhouse gas

reduction. Int. J. Coal Geol. 86, 121-156

Kędzior S (2009) The problem of emission and development of coal mine methane an example from chosen coal mines of the southern part of the Upper Silesian Coal Basin. Górnictwo Odkrywkowe, 2 - 3, 79-83 (in Polish with English abstract)

Kędzior S (2012) A near-roof gas-bearing zone in Carboniferous rocks of the southern part of the Upper Silesian Coal Basin occurrence, coal reservoir parameters and prospects for methane extraction. Wydawnictwo Uniwersytetu Śląskiego, Katowice, ISBN 978-83-226-2093-9 (in Polish with English abstract)

Kędzior S, Kotarba MJ, Pekała Z (2013) Geology, spatial distribution of methane content and origin of coalbed gases in Upper Carboniferous (Upper Mississippian and Pennsylvanian) strata in the south-eastern part of the Upper Silesia Coal Basin, Poland. International Journal of Coal Geology 105, 24-35

Kędzior S (2015) Emission and commercial utilization of coal mine methane in the Upper

Silesian Coal Basin illustrated by the example of Katowice Coal Holding Company.

Page 20/52 
Environ. Socio.-Econ. Stud. 3, 1-10.

Kędzior S (2019) Distribution of methane contents and coal rank in the profiles of deep boreholes in the Upper Silesian Coal Basin, Poland. International Journal of Coal Geology 202, 190- 208.

Kędzior S, Dreger M (2019) Methane occurrence, emissions and hazards in the Upper Silesian Coal Basin, Poland International Journal of Coal Geology, vol. 211, 103226.

Kosakowski P, Botor D, Kotarba M (1995) Attempt for assess of erosion magnitude and paleothermal conditions of coal-bearing series of the upper Carboniferous in the Upper Silesian Coal Basin. In: Ney, R., Kotarba, M. (Eds.), Study of Models and the balance of generation and accumulation of gases in coal-bearing series of the Upper Silesian Coal Basin. Publication Centrum PPGSMiE PAN, Kraków, pp. 41-51 (in Polish). ISBN: 83-86286-65-2.

Kotarba MJ (2001) Composition and origin of gases in the Upper Silesian and Lublin Coal Basins, Poland. Organic Geochemistry $32,163-180$.

Kotarba MJ, Pluta I (2009) Origin of natural waters and gases within the Upper Carboniferous coalbearing and autochthonous Miocene strata in South-Western part of the Upper Silesian Coal Basin, Poland. Applied Geochemistry 24, 876-889.

Kotas A (1982) The geological structure outline of the Upper Silesia Coal Basin. Przewodnik LIV Zjazdu PTG, 45-72 (in Polish)

Kotas A (1990) Upper Silesian Coal Basin. In: Osika R., (Ed.). Mineral Deposits: Geology of Poland VI. Geological Institute, Publishing House, Wyd. Geologiczne, Warszawa. ISBN: 83- 220-0385-4, pp. 77-92.

Kotas A(ed.) (1994) Coalbed Methane Potential of the Upper Silesian Coal Basin, Poland. Prace Państwowego Instytutu Geologicznego, 142, PIG, Warszawa

Kotas A (1995) Upper Silesian Coal Basin. In. Zdanowski A., Żakowa H. (eds), The Carboniferous System In Poland. Prace Państwowego Instytutu Geologicznego CXLVIII, ISSN 0866-9465, pp. 124-134.

Kozłowski B (1982) Gazy kopalniane - Kontrola, prognoza, zwalczanie. Wydawnictwo PWN, Warszawa - Kraków

Kozłowski B, Grębski Z (1982) Hard coal mines degassing processes. Publ. Śląsk, Katowice (in Polish)

Kozłowski B (1986) Prognozowanie zagrożeń metanowych w kopalniach głębinowych. Skrypty uczelniane nr 1300, Politechnika Śląska, Gliwice

Krause E (2019) The methane hazards in hard coal mines. Zagrożenie metanowe w kopalniach węgla kamiennego, Central Mining Institute (GIG), Katowice

Lama RD, Bodziony J (1998) Management of outburst in underground coal mines. International Journal of Coal Geology, 35, 83115

Lamberson MN, Bustin RM (1993) Coalbed methane characteristics of Gates Formation coals, northeastern British Columbia: effect of maceral composition: AAPG Bulletin, vol 77 p. 2062-2076

Lunarzewski LLW (1998) Gas emission prediction and recovery in underground coal

mines. Int. J. Coal Geol. 35 (1), 117-145.

Malon A, Tymiński M (2020) Hard coal. In. The Balance-sheet of Mineral Resources in Poland (Szuflicki M, Malon A, Tymiński M, eds.). Polish Geological Institute, Warszawa (in Polish), ISSN 2299-4459.

Myszor H (1976) Możliwość intensyfikacji wydobycia ze ścian z uwagi na zagrożenie metanowe. Praca habilitacyjna, Prace GIG, Katowice

Page 21/52 
Noack K (1998) Control of gas emissions in underground coal mines. Int. J. Coal Geol.

$35,57-82$.

Report 1995-2019- Annual Report, 1995-2019. Annual Report (for the years 1994-2018) on the state of basic natural and technical hazards in the hard coal mining industry. Gas hazard. Publ. GIG, Katowice (in Polish)

Scott A (2002) Hydrogeologic factors affecting gas content distribution in coal beds. International Journal of Coal Geology 50, 363-387.

Skoczylas N, Wierzbicki M (2014) Evaluation and management of the gas and rock outburst hazard in the light of international legal regulations. Arch. Min. Sci., Vol. 59 (2014), No 4, p. 1119- 1129

Słoczyński T, Drozd A (2018) Methane potential of the Upper Silesian Coal Basin carboniferous strata - 4D petroleum system modelling results. Nafta-Gaz, 10, 703-714. DOI: 10.18668/ NG.2018.10.01

State Mining Authority - State Mining Authority in Katowice Statystyki Wypadków, available online June 2019 [http://www.wug.gov.pl/bhp/statystyki_wypadkow]

Stączek A, Simka A (2004) Graniczny wskaźnik intensywności desorpcji gazu z węgla charakteryzujący stan zagrożenia metanowego oraz wyrzutami metanu i skał. Prace Naukowe GIG 3/2004. Katowice (in Polish with English abstract)

Su S, Beath A, Guo H, Mallett C (2005) An assessment of mine methane mitigation and

utilisation technologies. Prog. Energy Combust. 31 (2), 123-170.

Tarnowski J (1971) Wystepowanie metanu w złożu południowej części Rybnickiego Okręgu Węglowego. Prace GIG, Katowice

Tarnowski J (1989) Geologiczne warunki występowania metanu w Górnośląskiej Niecce Węglowej. Zeszyty naukowe Politechniki Śląskiej vol 166. Gliwice

Teper L, Sagan G (1995) Geological history and mining seismicity in Upper Silesia (Poland), In: H.P. Rossmanith(ed.)Mechanics of Jointed and Faulted Rock,Balkema, Rotterdam, 939- 943

Thielemann T, Kroos BM, Littke R, Welte DH (2001) Does coal mining induce

methane emissions through the lithosphere/atmosphere boundary in the Ruhr Basin,

Germany? J. Geochem. Explor. 74, 219-231.

Turek M (2007) Hard coal mines technical and organizational restructuring processes. Central Mining Institute (GIG), Katowice (in Polish)

Regulation of the ministry of the environment - Rozporządzenie Ministra Gospodarki z dnia 28 czerwca 2002 r. w sprawie bezpieczeństwa i higieny pracy, prowadzenia ruchu oraz specjalistycznego zabezpieczenia przeciwpożarowego w podziemnych zakładach górniczych. (Dz.U. 2002 nr 139 poz. 1169)

Regulation of the ministry of the environment- Rozporządzenie Ministra Środowiska z dnia 29 stycznia $2013 \mathrm{r}$. w sprawie zagrożeń naturalnych w zakładach górniczych. Na podstawie art. 118 ust. 4 ustawy z dnia 9 czerwca 2011 r. - Prawo geologiczne i górnicze (Dz. U. Nr 163, poz. 981 oraz z 2013 r. poz. 21)

Warmuziński K (2008) Harnessing methane emissions from coal mining. Process. Sav.

Environ. 86, 315-320. 
Wierzbicki M, Skoczylas N (2014) The outburst risk as a function of the methane capacity and firmness of a coal seam. Arch. Min. Sci., Vol. 59 (2014), No 4, p. 1023-1031

Working Mine Methane- Working Mine Methane (Coal Mine Methane) https://www.clarke- energy.com/coal-gas/working-minemethane/ available 23.11.2019

Yusuf RO, Noor ZZ, Abba, AH, Hassan MAA, Din MFM (2012) Methane emission by

sectors: a comprehensive review of emission sources and mitigation methods.

Renew. Sust. Energ. Rev. 16 (7), 5059-5070.

\section{Figures}

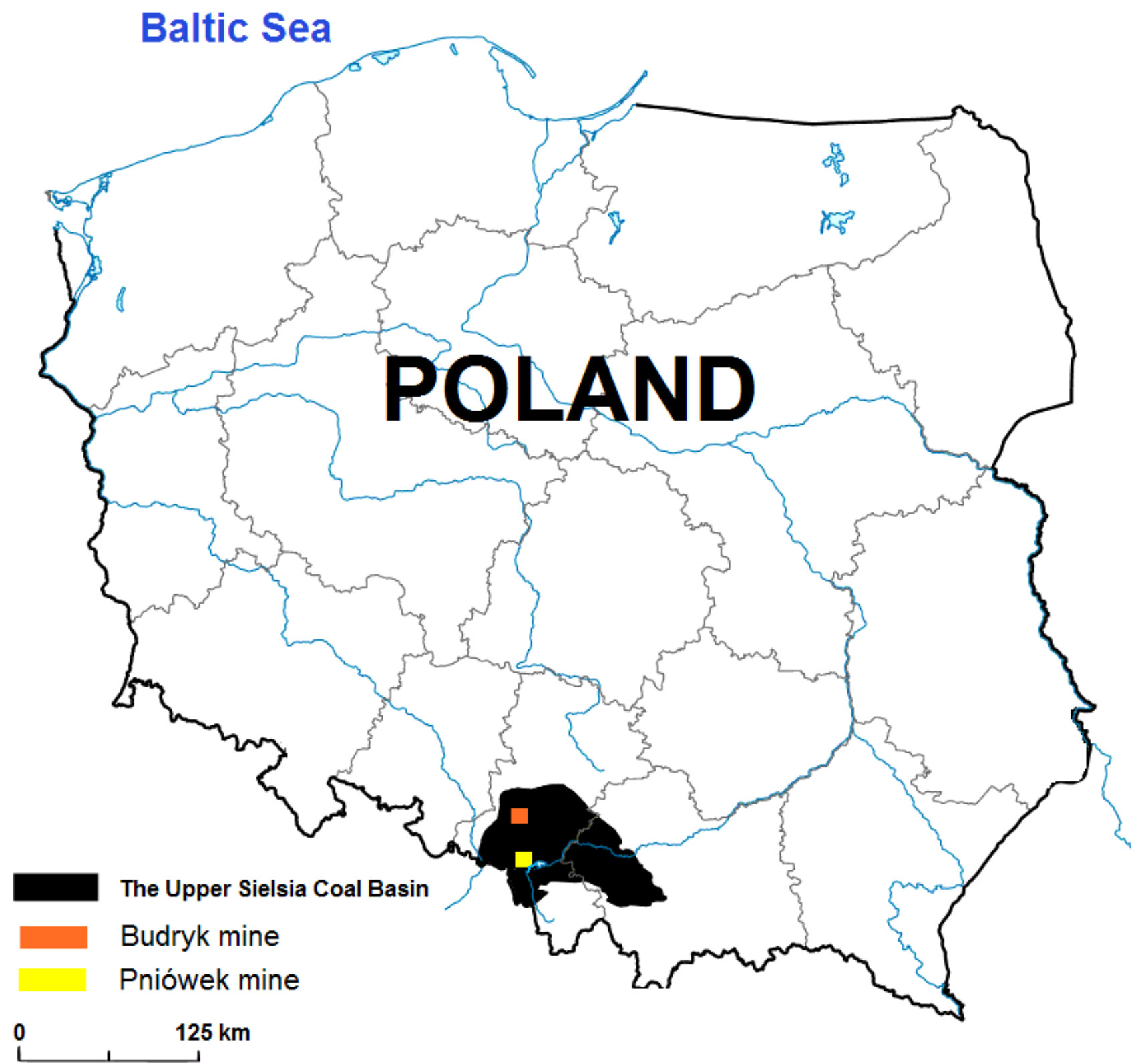

Figure 1 
Location of the Budryk and Pniówek coal mines in the Upper Silesian Coal Basin. Note: The designations employed and the presentation of the material on this map do not imply the expression of any opinion whatsoever on the part of Research Square concerning the legal status of any country, territory, city or area or of its authorities, or concerning the delimitation of its frontiers or boundaries. This map has been provided by the authors.

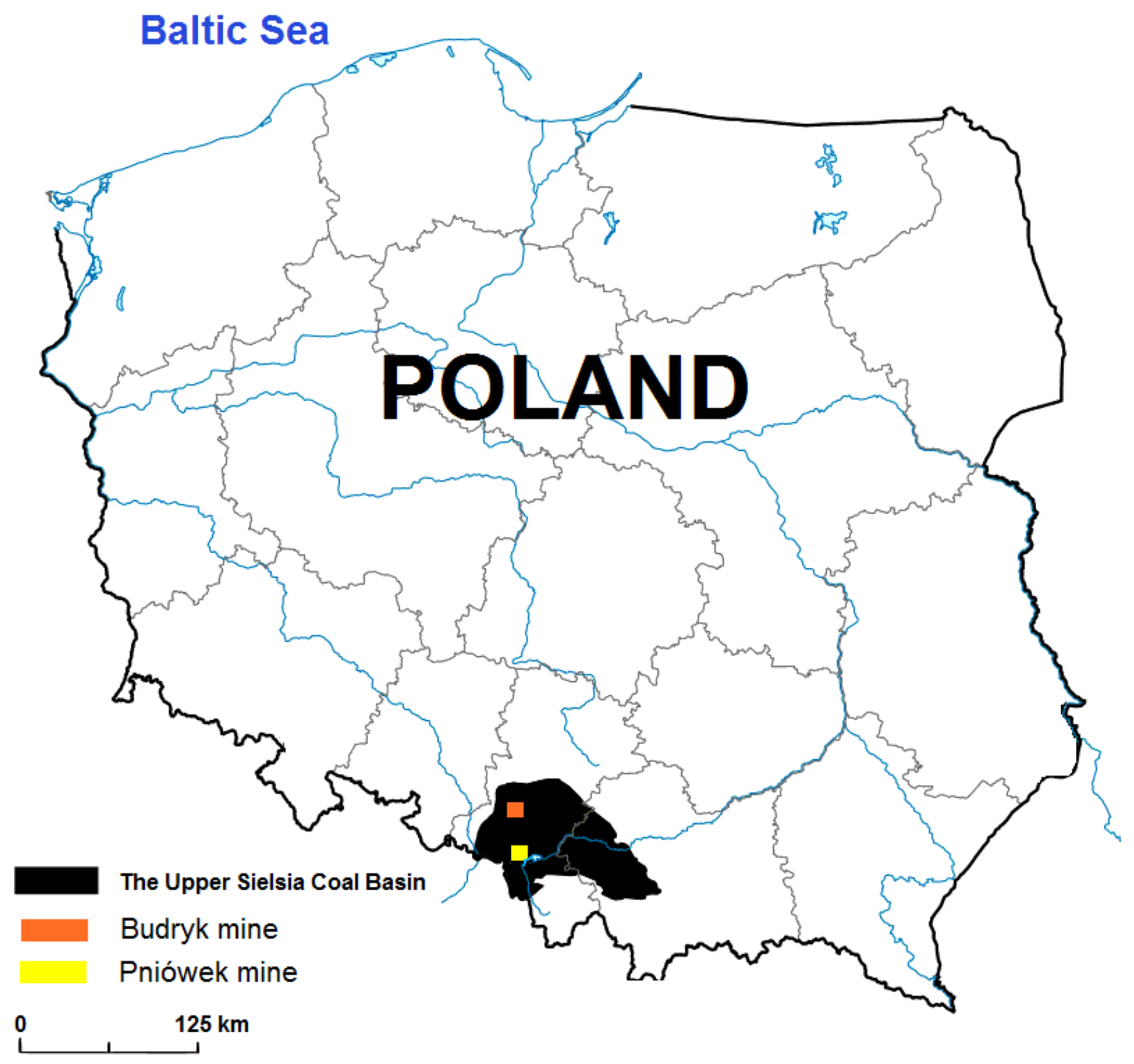

Figure 2

Location of the Budryk and Pniówek coal mines in the Upper Silesian Coal Basin. Note: The designations employed and the presentation of the material on this map do not imply the expression of any opinion whatsoever on the part of Research Square concerning the legal status of any country, territory, city or area or of its authorities, or concerning the delimitation of its frontiers or boundaries. This map has been provided by the authors. 


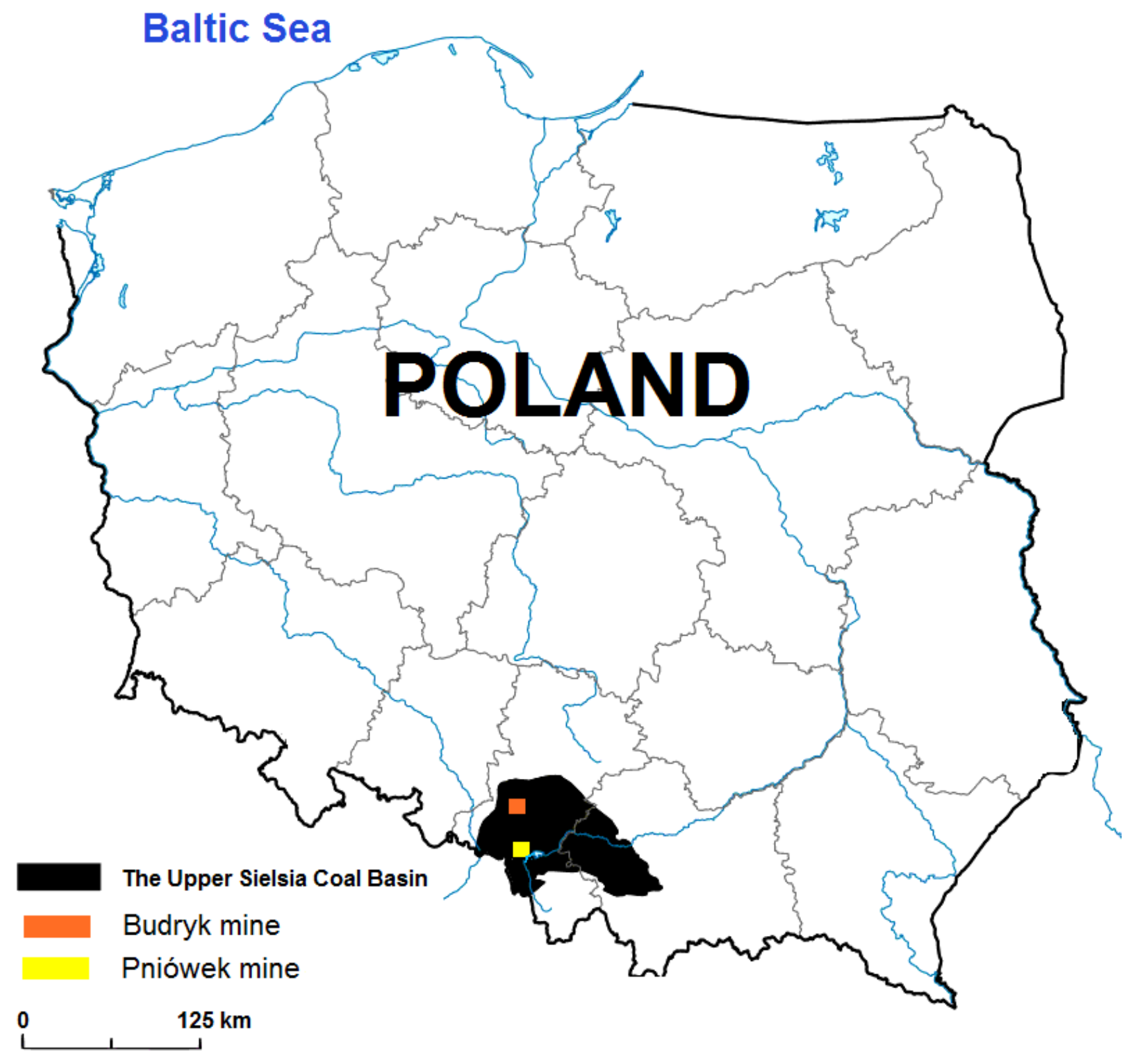

Figure 2

Location of the Budryk and Pniówek coal mines in the Upper Silesian Coal Basin. Note: The designations employed and the presentation of the material on this map do not imply the expression of any opinion whatsoever on the part of Research Square concerning the legal status of any country, territory, city or area or of its authorities, or concerning the delimitation of its frontiers or boundaries. This map has been provided by the authors. 


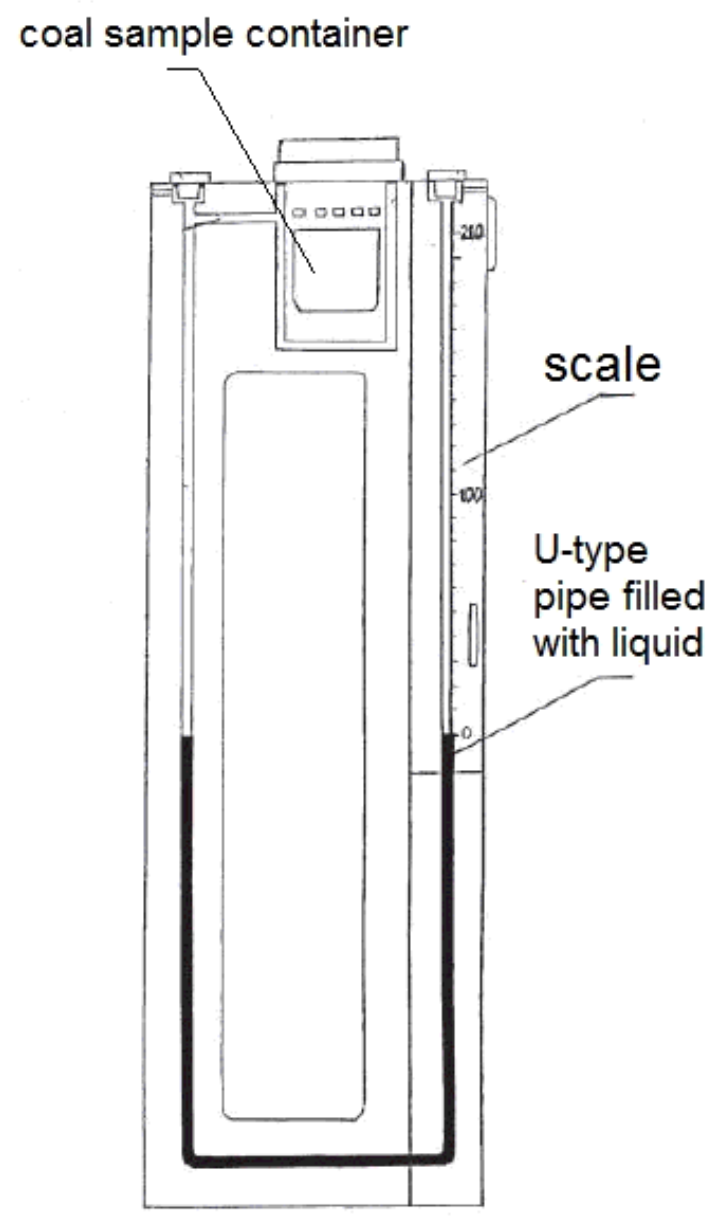

Figure 2

Desorbometer DMC-2 used in Polish underground coal mines 


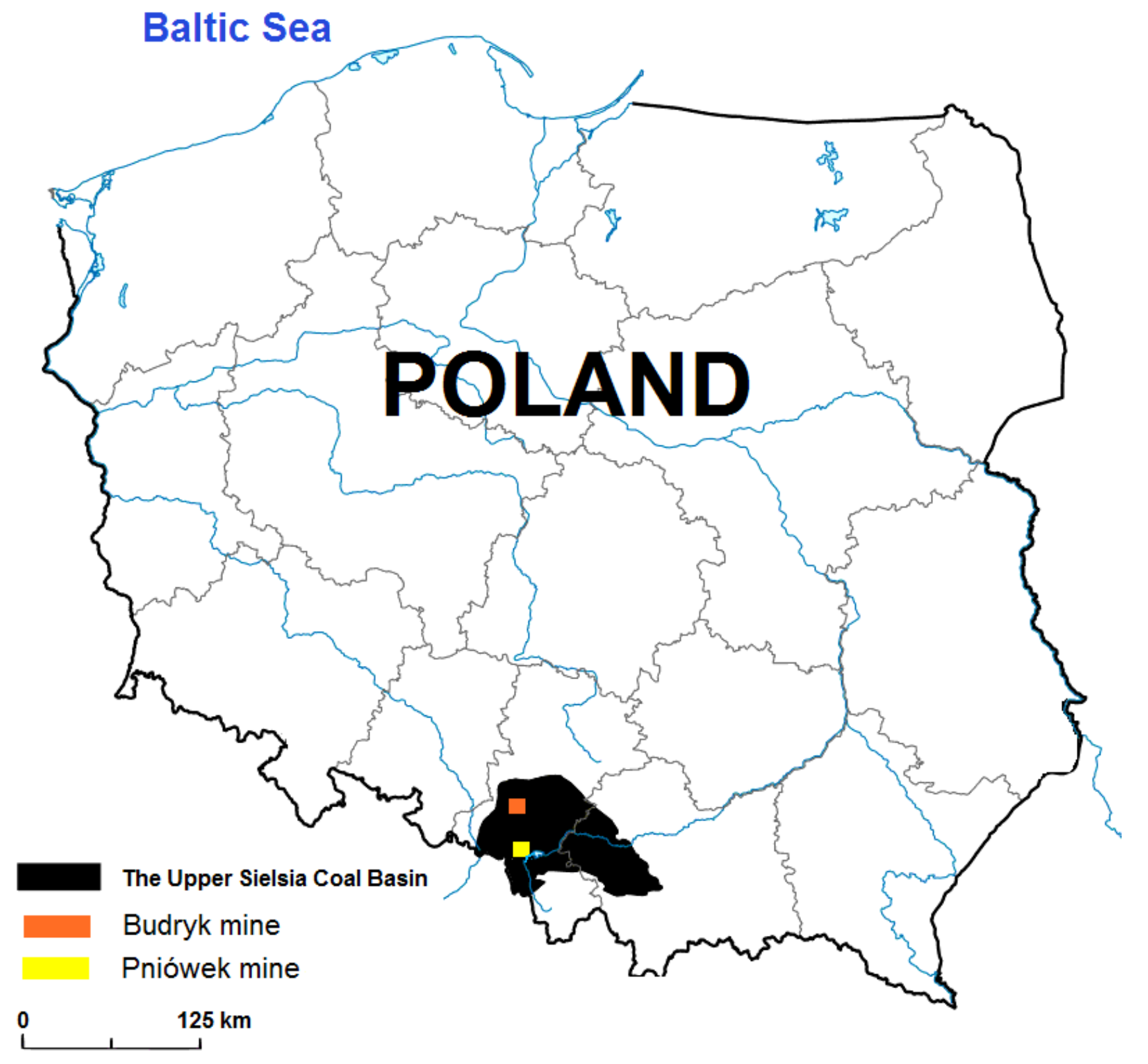

Figure 2

Location of the Budryk and Pniówek coal mines in the Upper Silesian Coal Basin. Note: The designations employed and the presentation of the material on this map do not imply the expression of any opinion whatsoever on the part of Research Square concerning the legal status of any country, territory, city or area or of its authorities, or concerning the delimitation of its frontiers or boundaries. This map has been provided by the authors. 


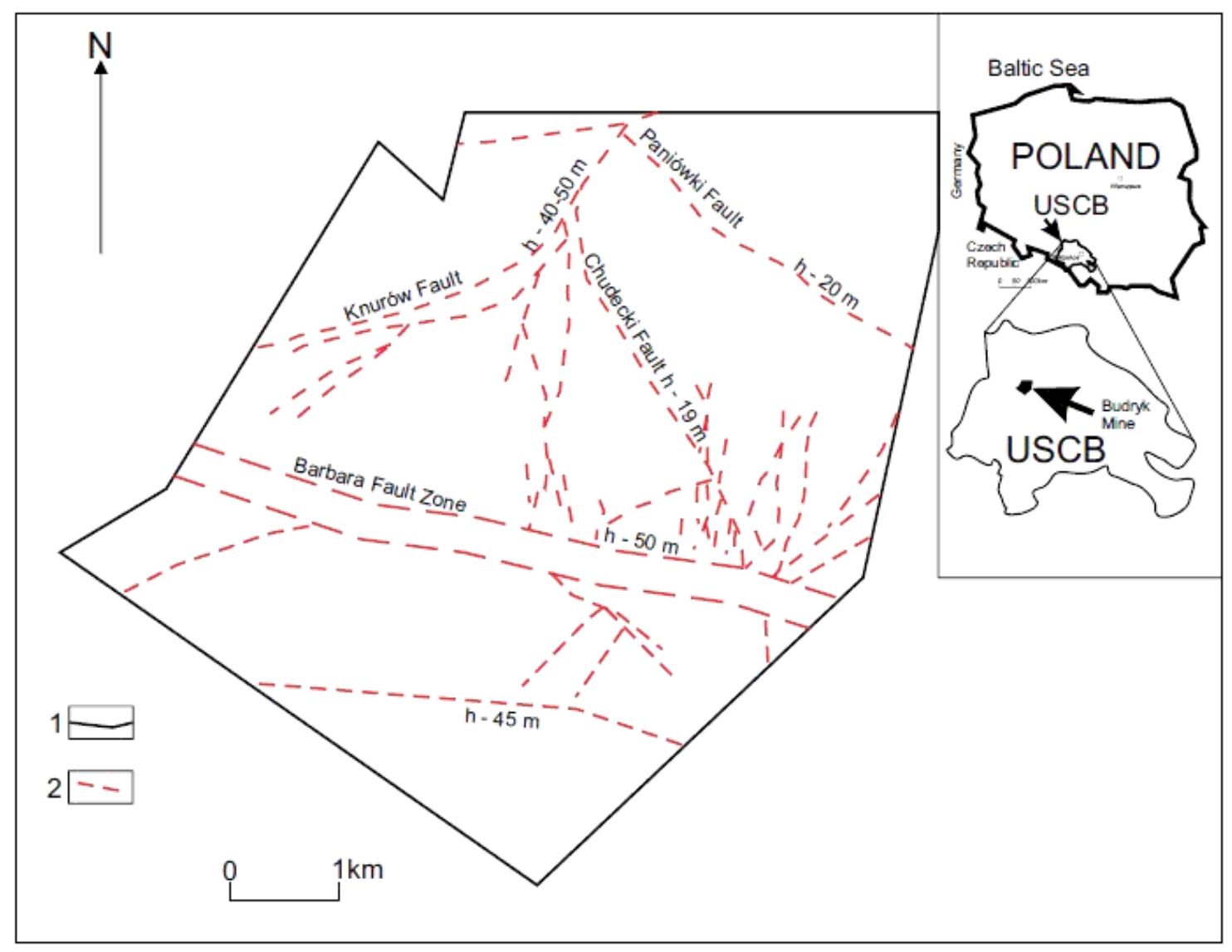

Figure 3

Tectonic sketch of the Budryk Mine (402 coal seam), 1 - the boundaries of the mining field of the Budryk mine, 2 - faults with throw size h, 


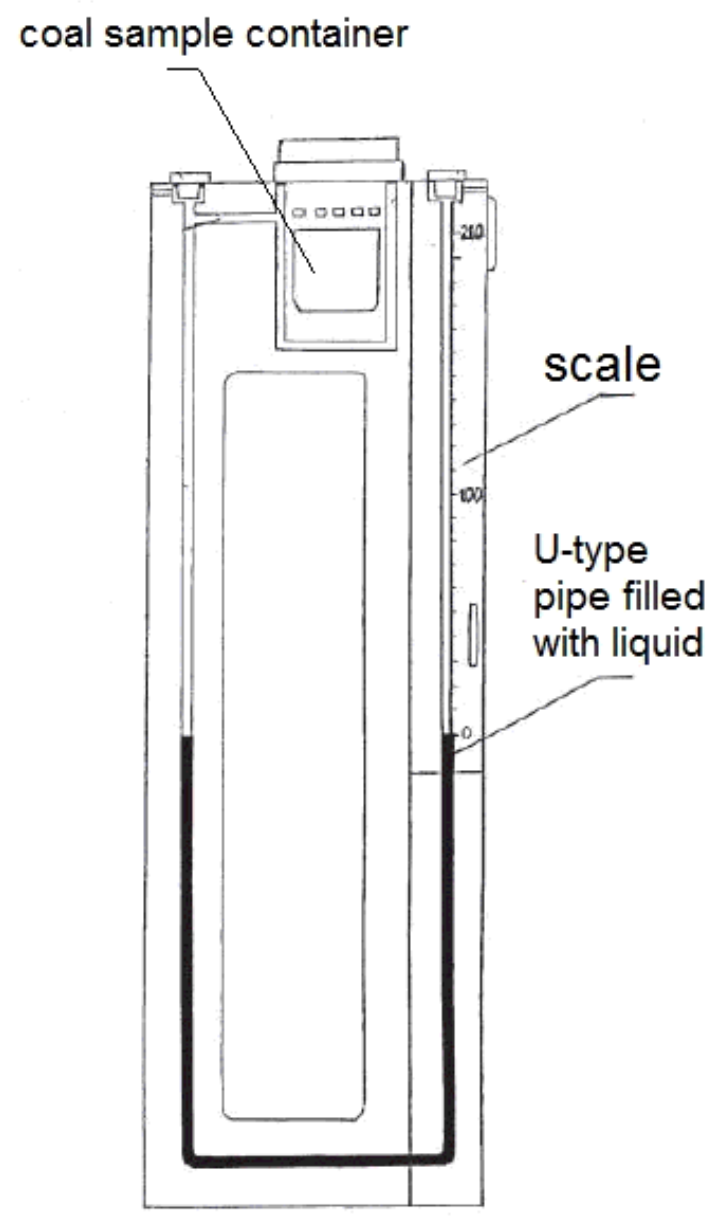

Figure 3

Desorbometer DMC-2 used in Polish underground coal mines 


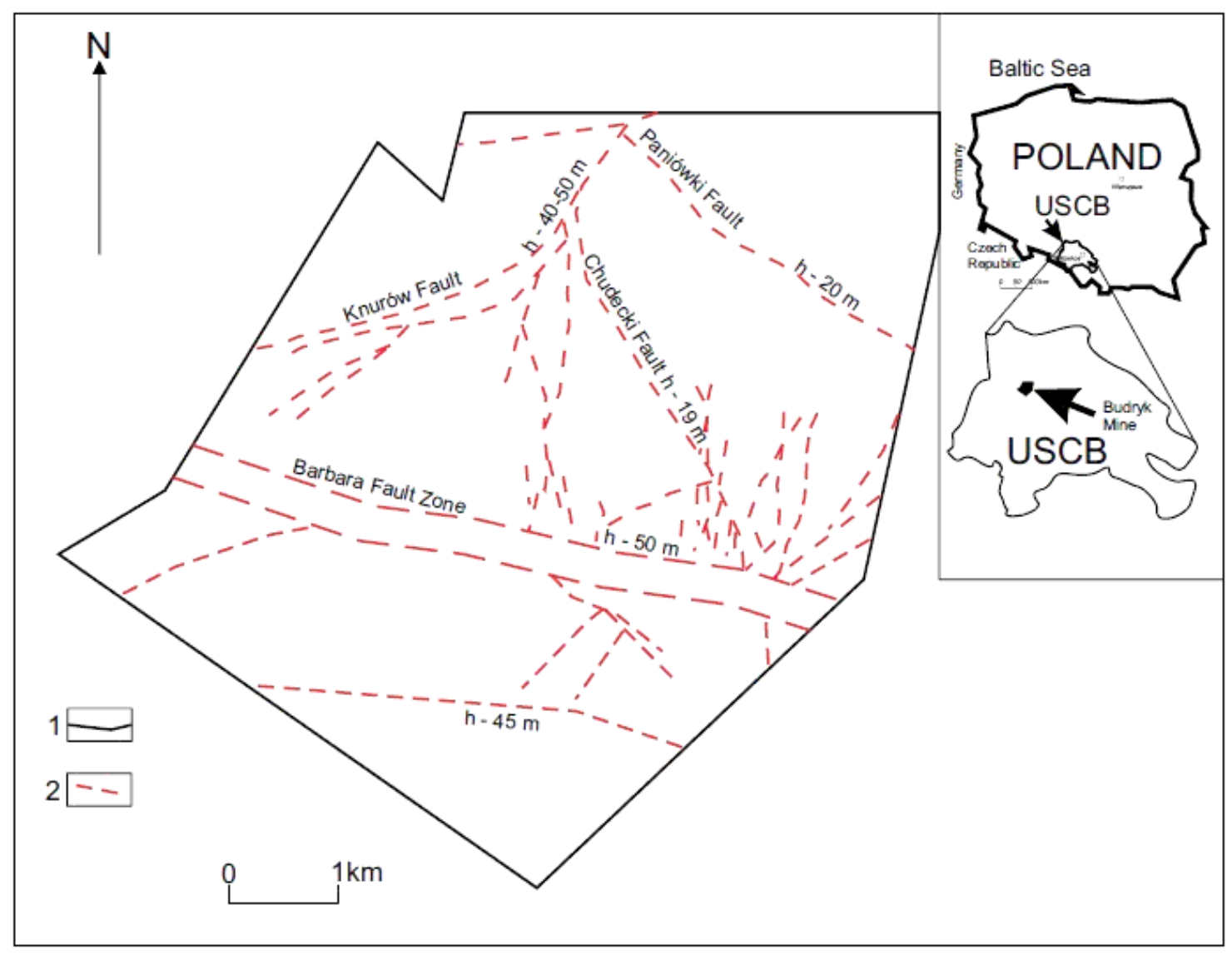

\section{Figure 4}

Tectonic sketch of the Budryk Mine (402 coal seam), 1 - the boundaries of the mining field of the Budryk mine, 2 - faults with throw size h, 


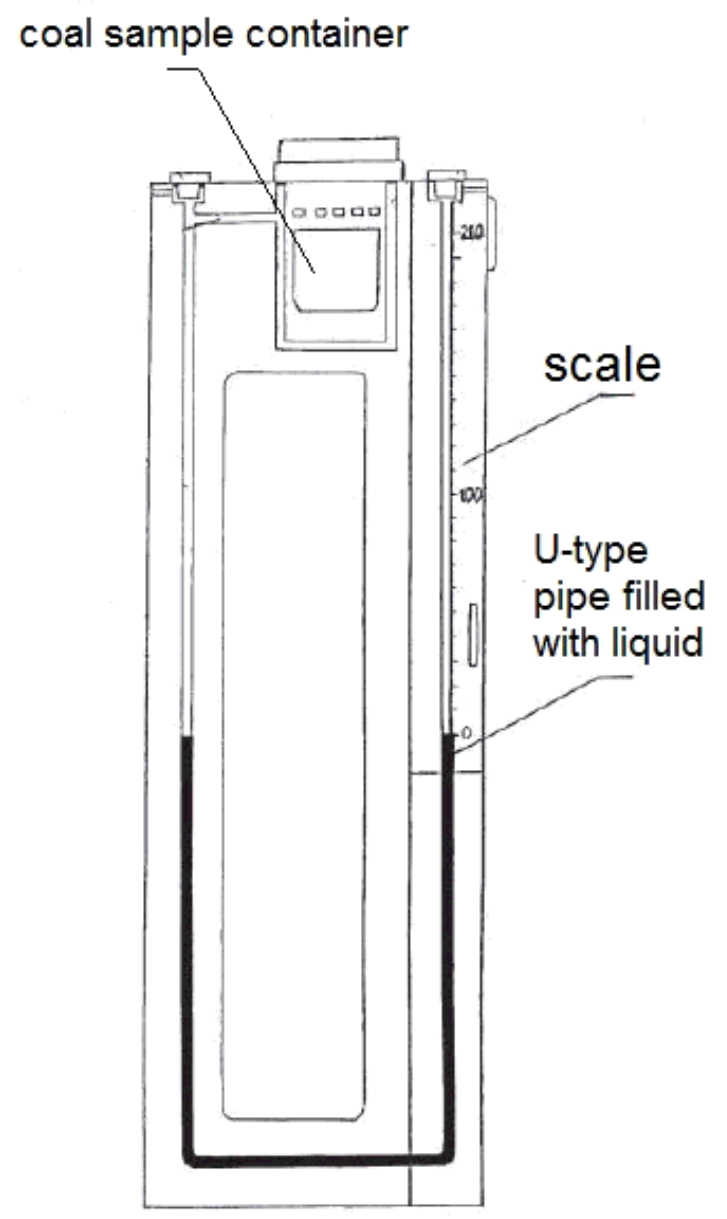

Figure 4

Desorbometer DMC-2 used in Polish underground coal mines 
coal sample container

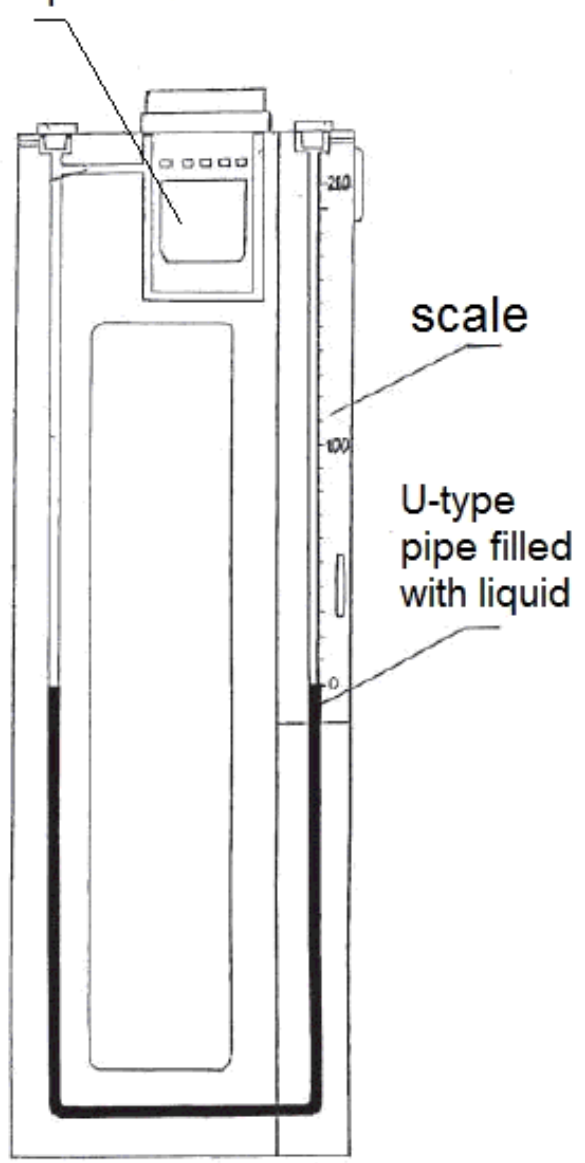

Figure 4

Desorbometer DMC-2 used in Polish underground coal mines

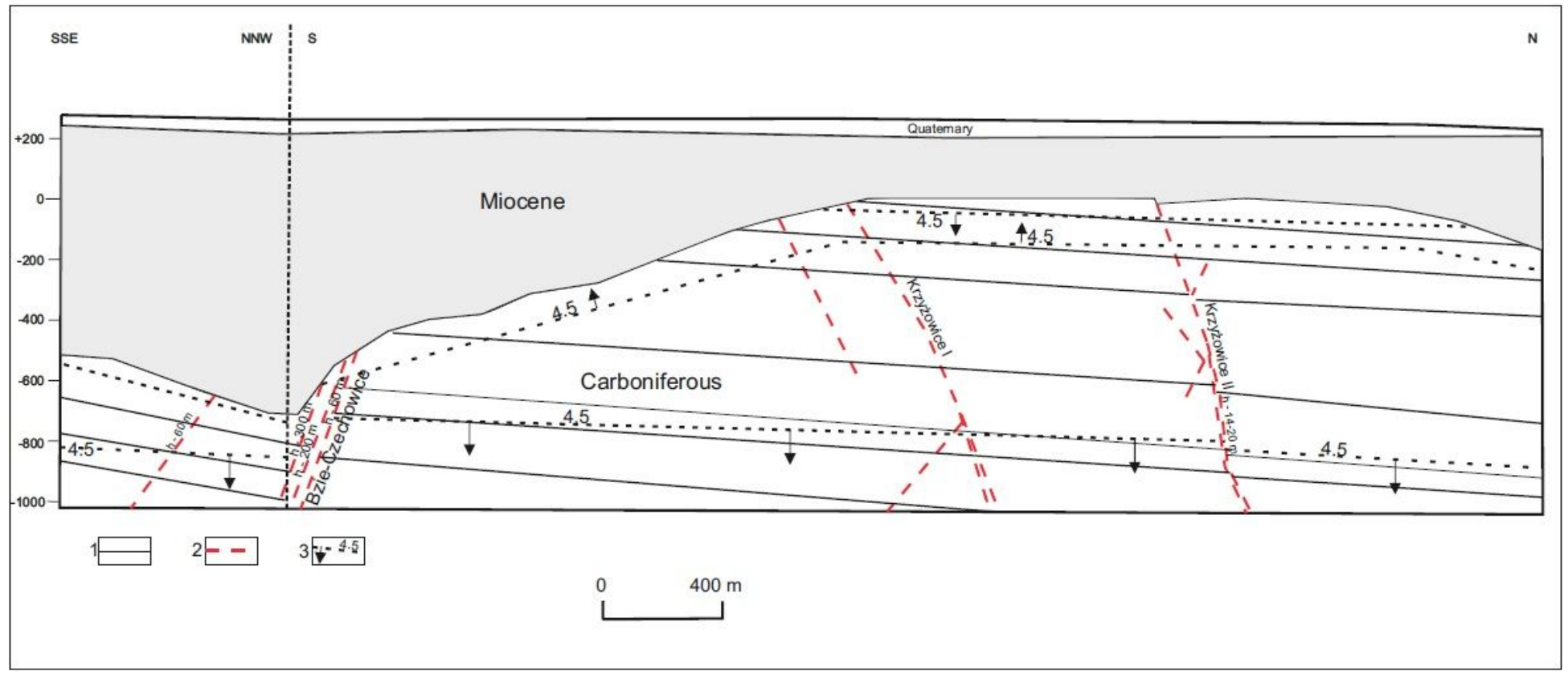

Figure 4 
The cross-section across the Pniówek Mine, 1 - the more important coal seams, 2 - fault with throw size h, 3 - line of methane content $4.5 \mathrm{~m} 3$ / t coaldaf, increase in methane content in the direction of the arrow

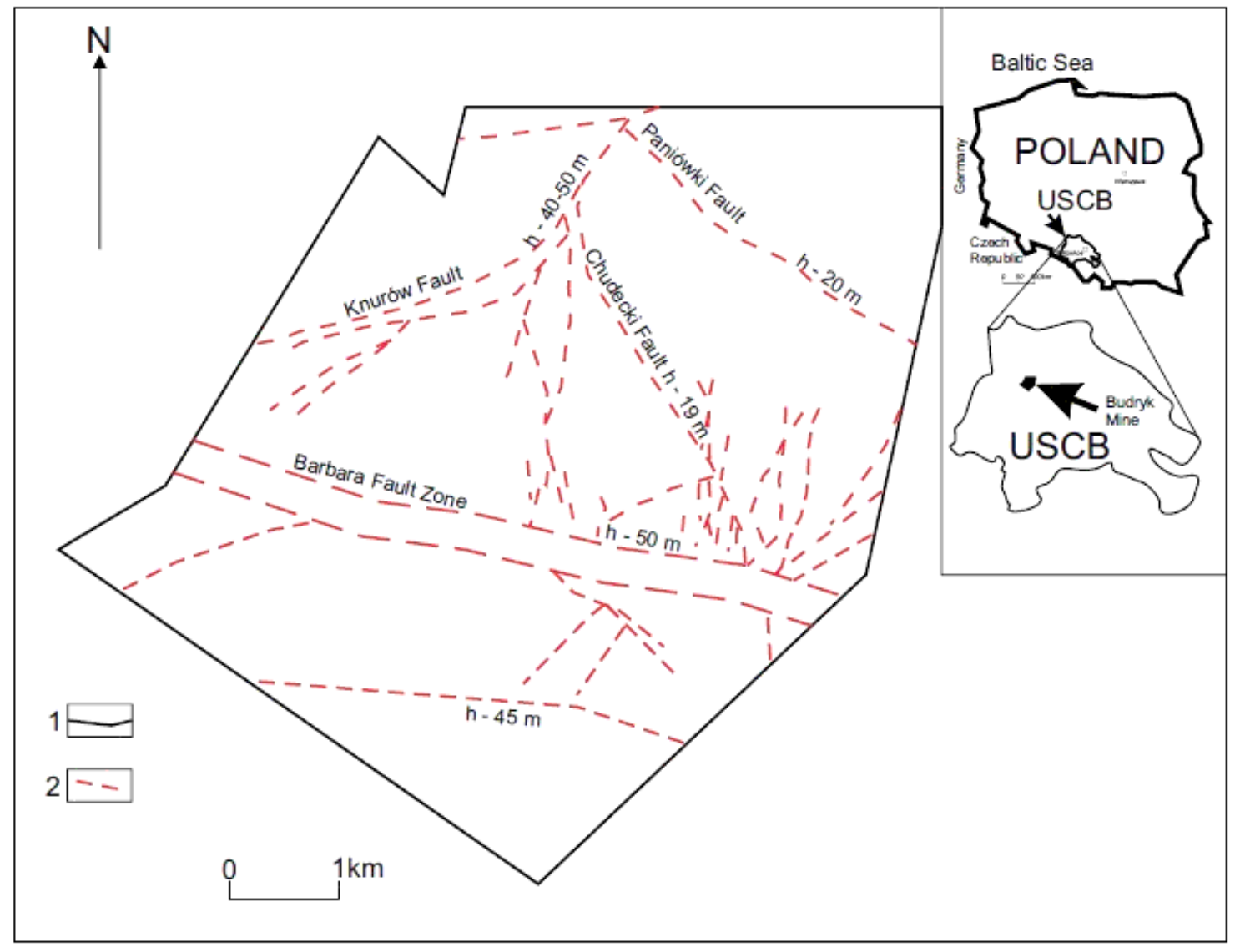

\section{Figure 5}

Tectonic sketch of the Budryk Mine (402 coal seam), 1 - the boundaries of the mining field of the Budryk mine, 2 - faults with throw size h, 

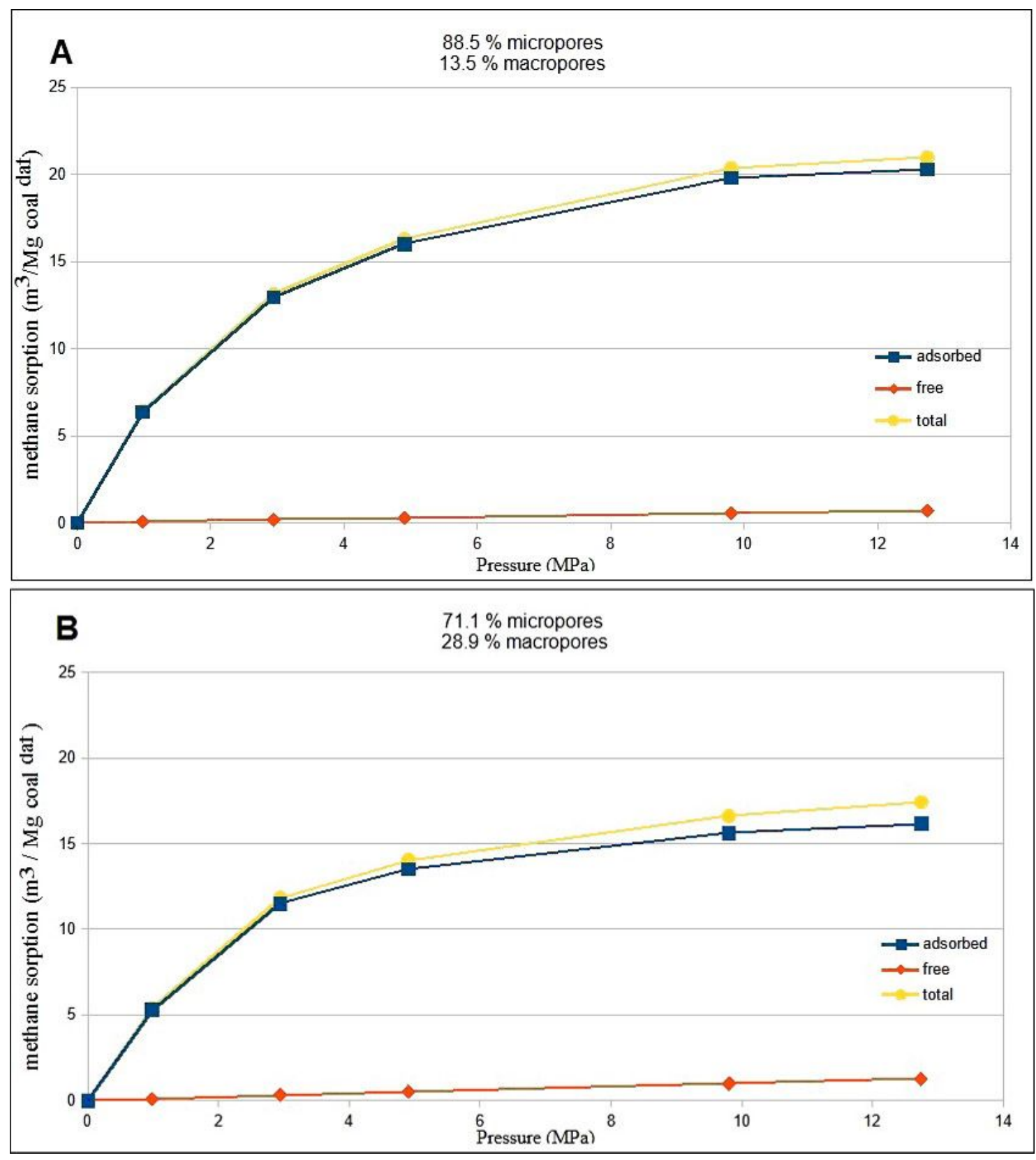

\section{Figure 5}

a The sorption capacity of the microporous and macroporous coals (88.5\% macroporous) (Kozłowski and Grębski 1982) b The sorption capacity of the microporous and macroporous coals (71.1\% macroporous)(Kozłowski and Grębski 1982) 


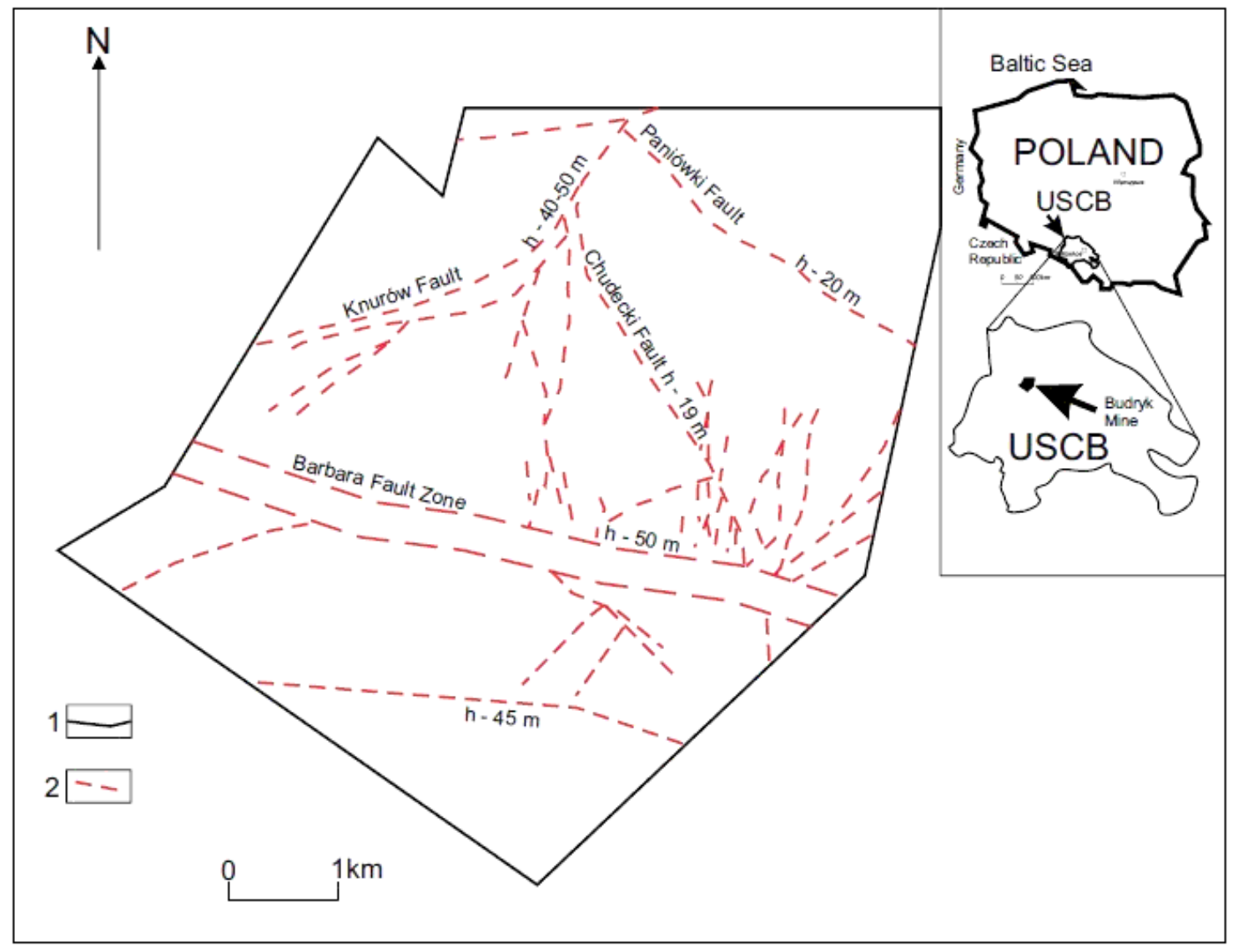

\section{Figure 5}

Tectonic sketch of the Budryk Mine (402 coal seam), 1 - the boundaries of the mining field of the Budryk mine, 2 - faults with throw size h,

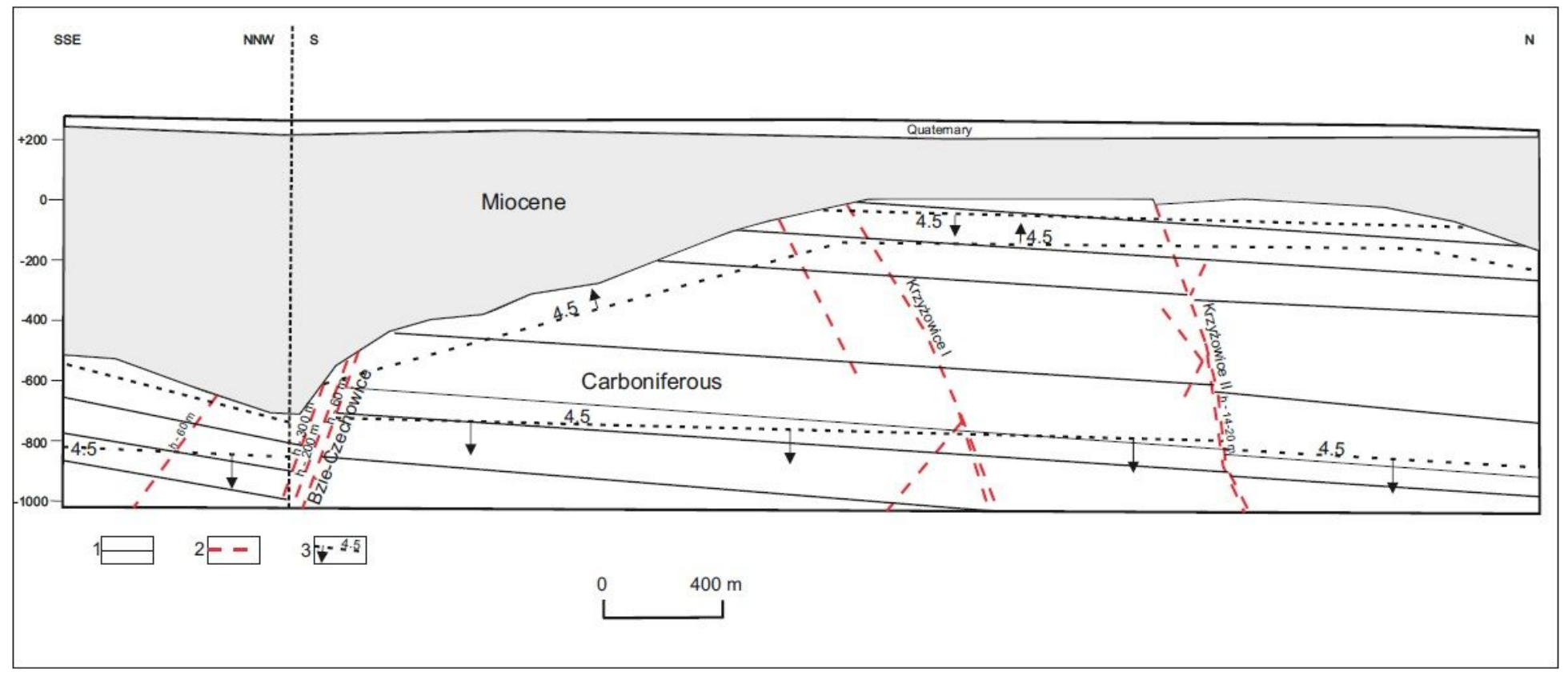

Figure 6

The cross-section across the Pniówek Mine, 1 - the more important coal seams, 2 - fault with throw size h, 3 - line of methane content $4.5 \mathrm{~m} 3$ / $\mathrm{t}$ coaldaf, increase in methane content in the direction of the arrow 


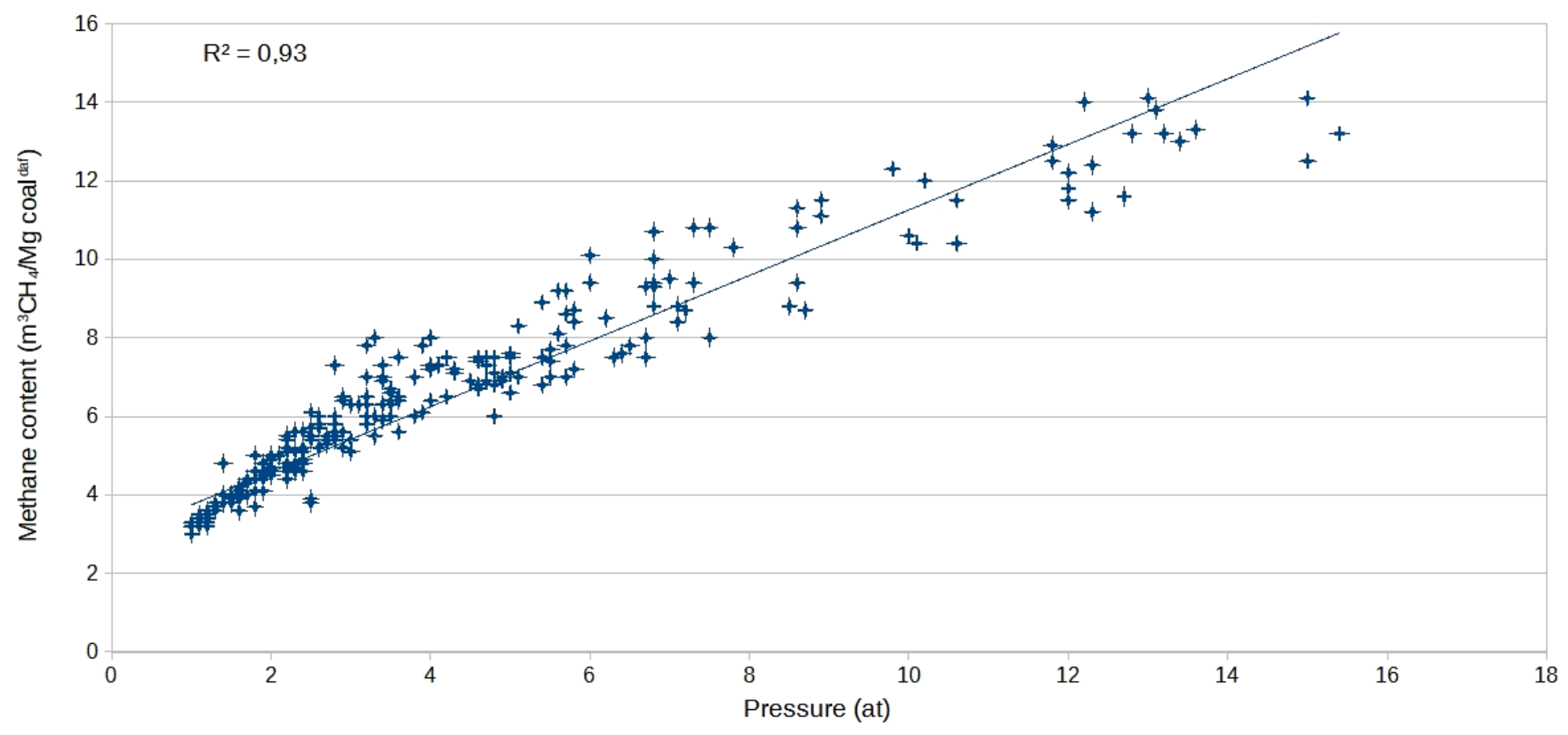

Figure 7

The methane content and coal seam pressure studied in the USCB coal mines (Tarnowski 1971)

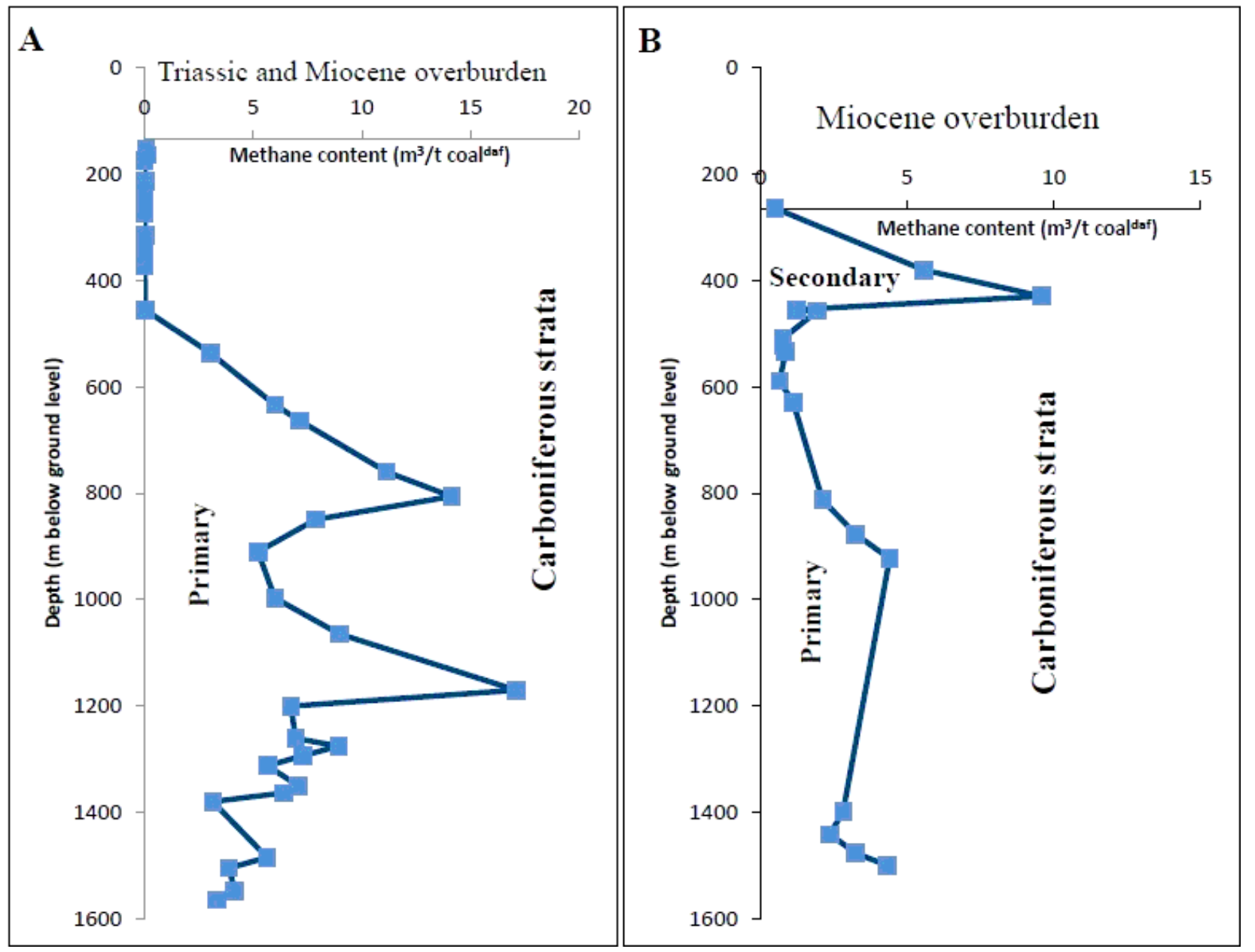

Figure 7 
Methane depth distribution in the Budryk(A) and Pniówek (B) mines. Primary - the primary methane zone in depth profile, Secondary - the secondary methane zone in depth profile

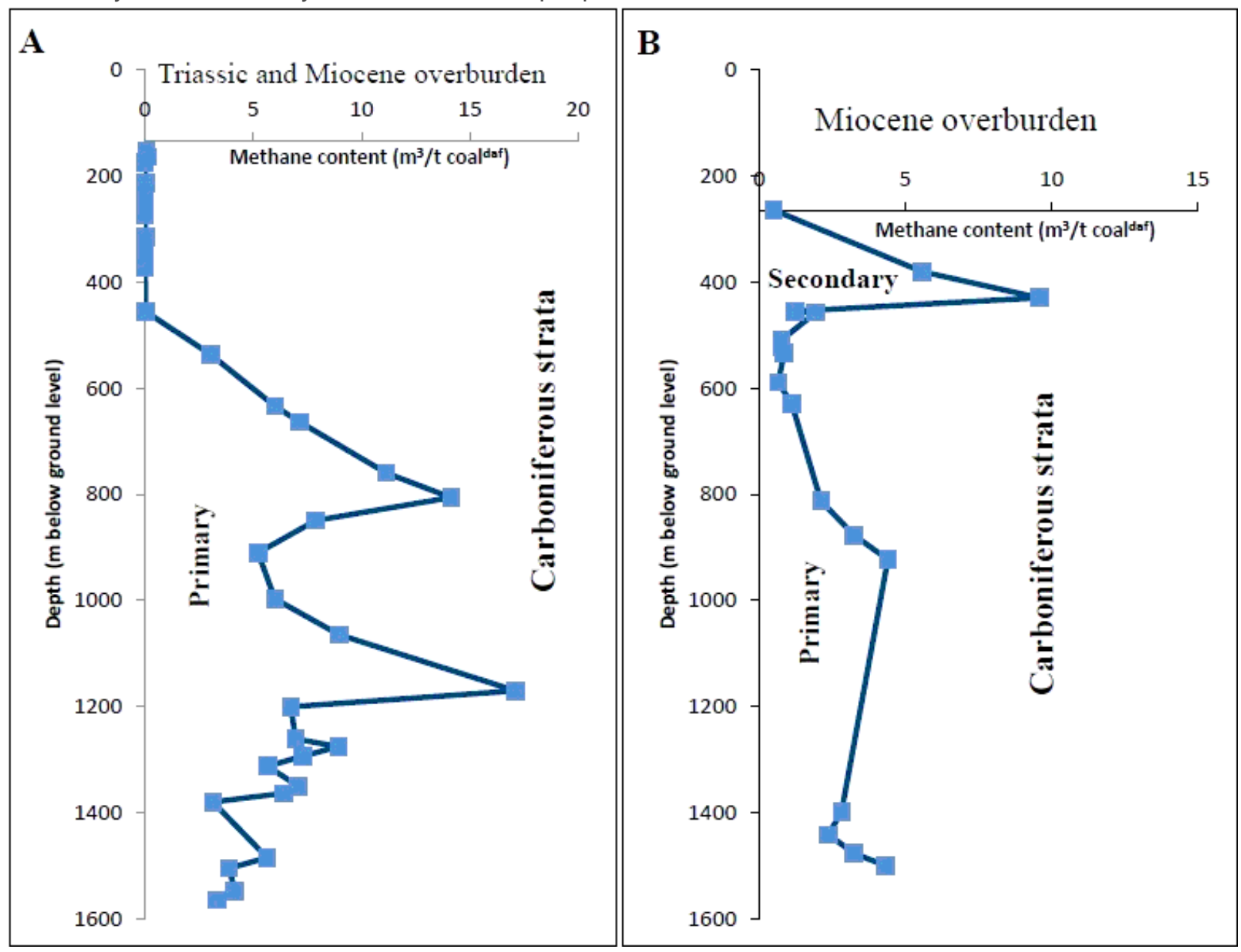

\section{Figure 8}

Methane depth distribution in the Budryk(A) and Pniówek (B) mines. Primary - the primary methane zone in depth profile, Secondary - the secondary methane zone in depth profile 


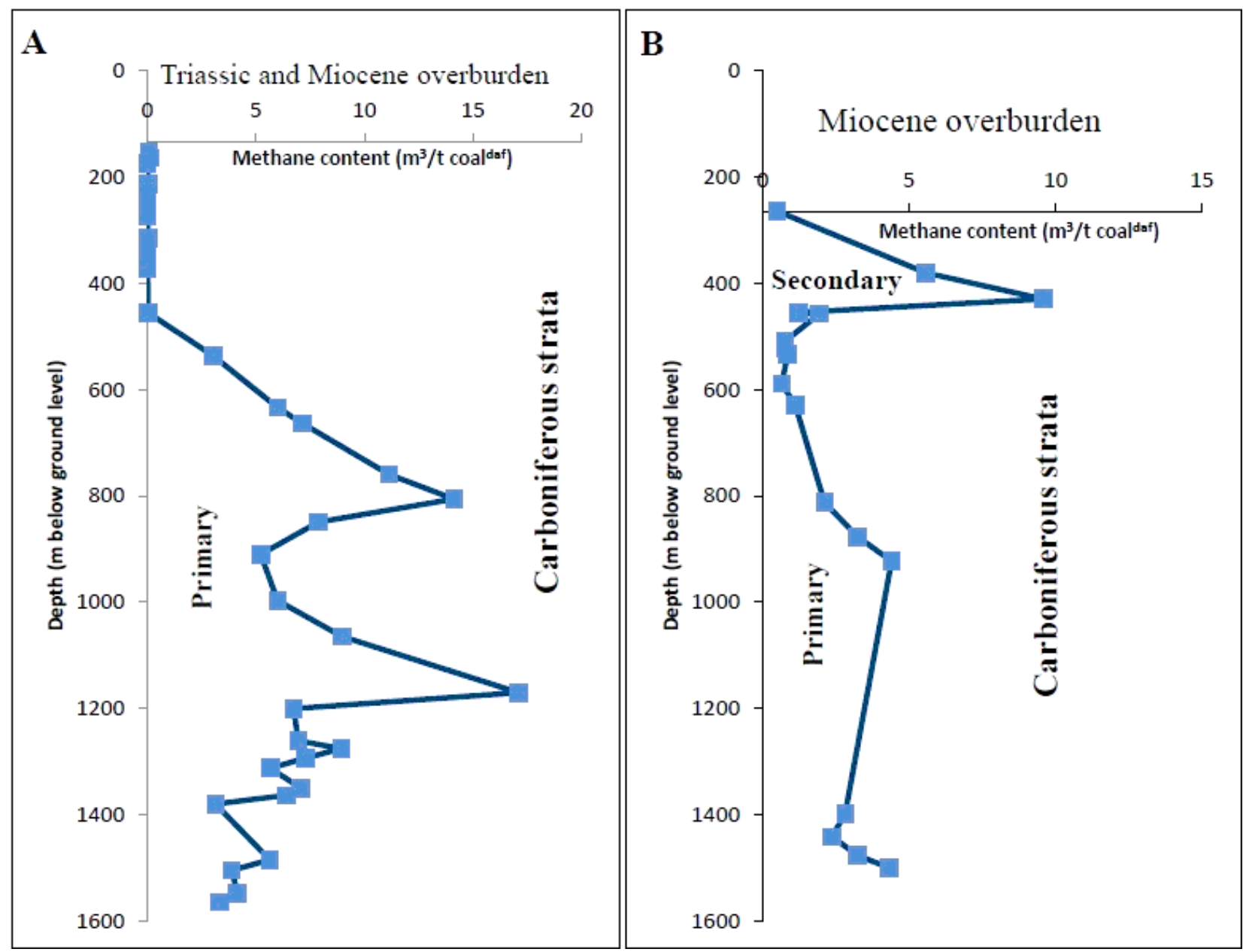

\section{Figure 8}

Methane depth distribution in the Budryk(A) and Pniówek (B) mines. Primary - the primary methane zone in depth profile, Secondary - the secondary methane zone in depth profile 

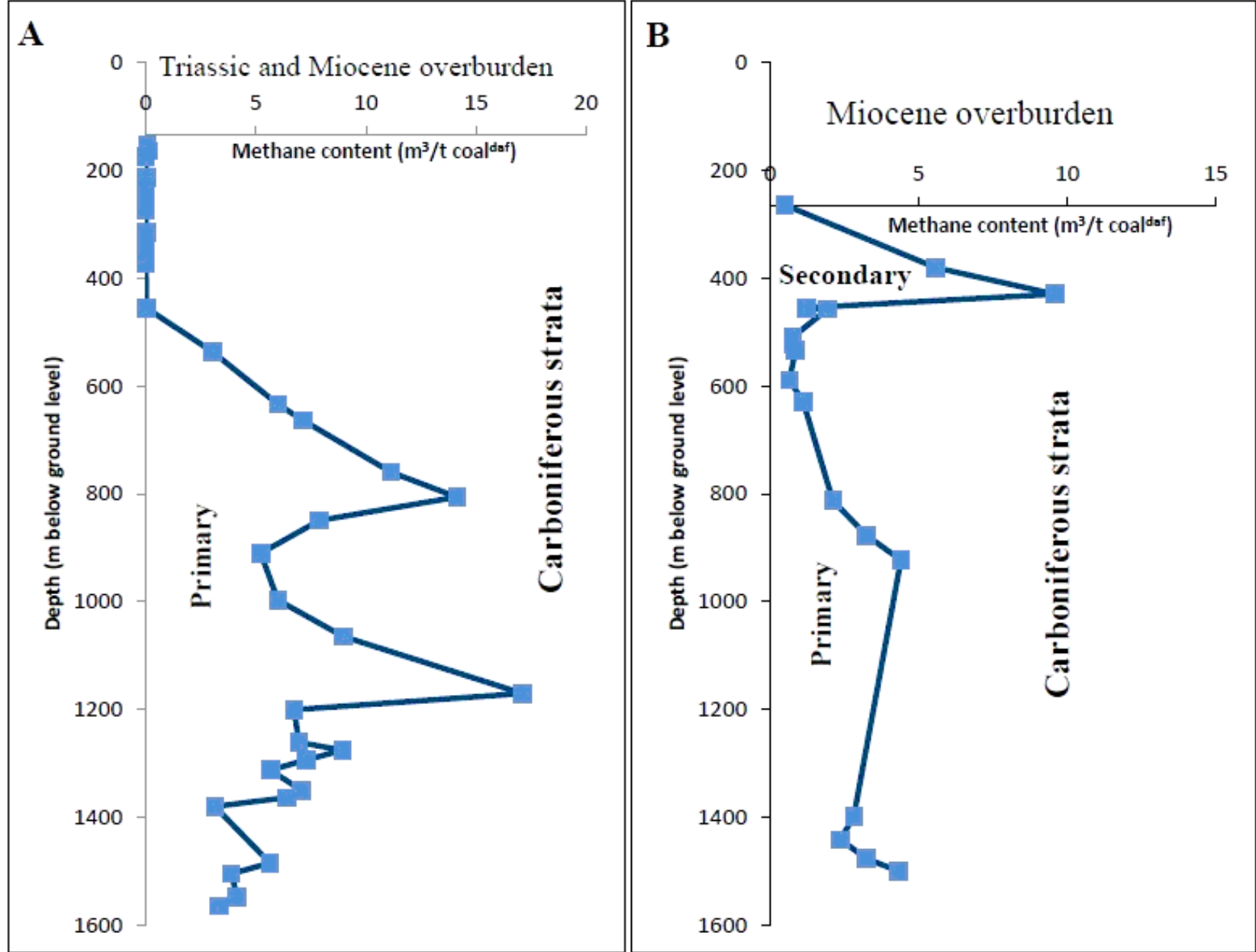

Figure 8

Methane depth distribution in the Budryk(A) and Pniówek (B) mines. Primary - the primary methane zone in depth profile, Secondary - the secondary methane zone in depth profile

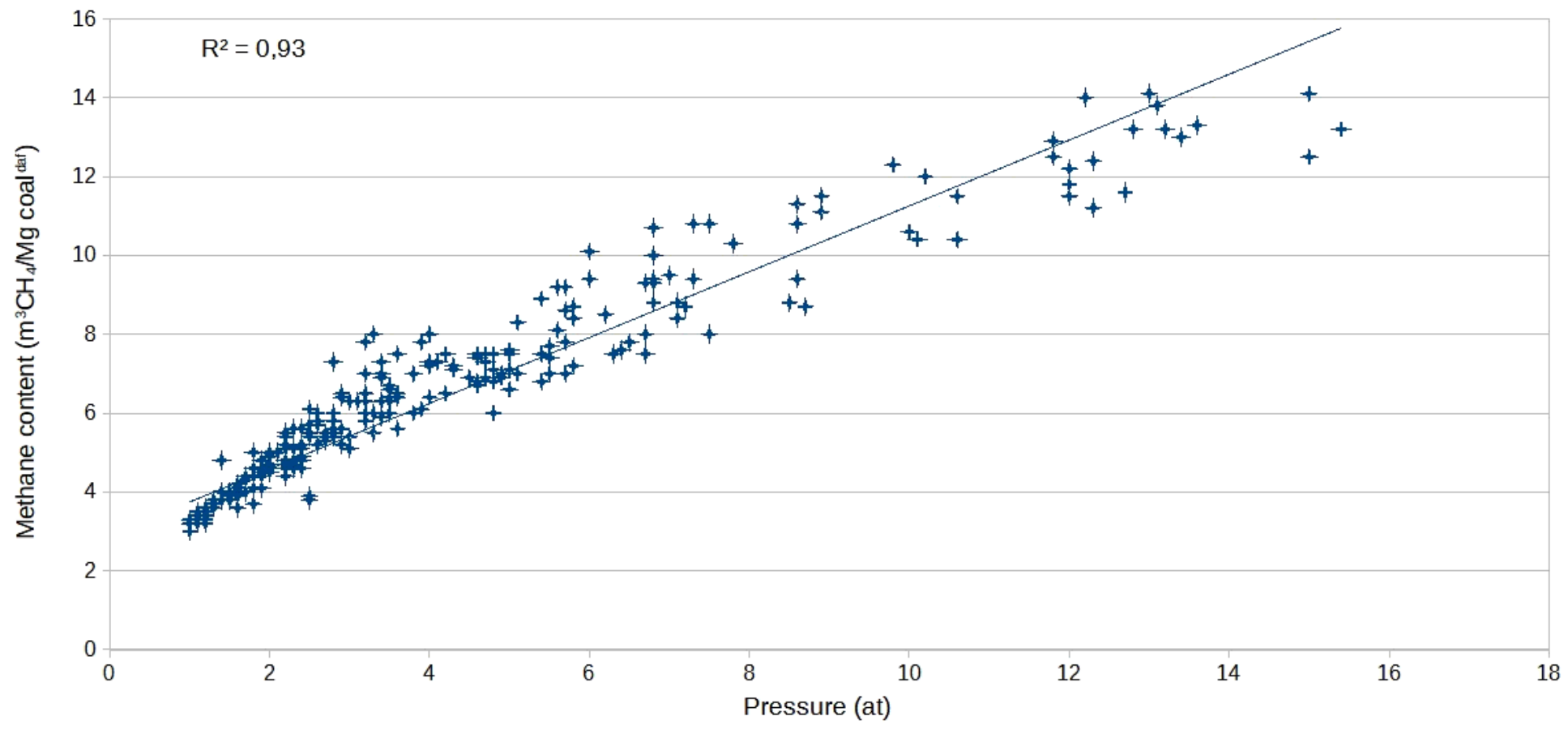

Figure 9 
The methane content and coal seam pressure studied in the USCB coal mines (Tarnowski 1971)
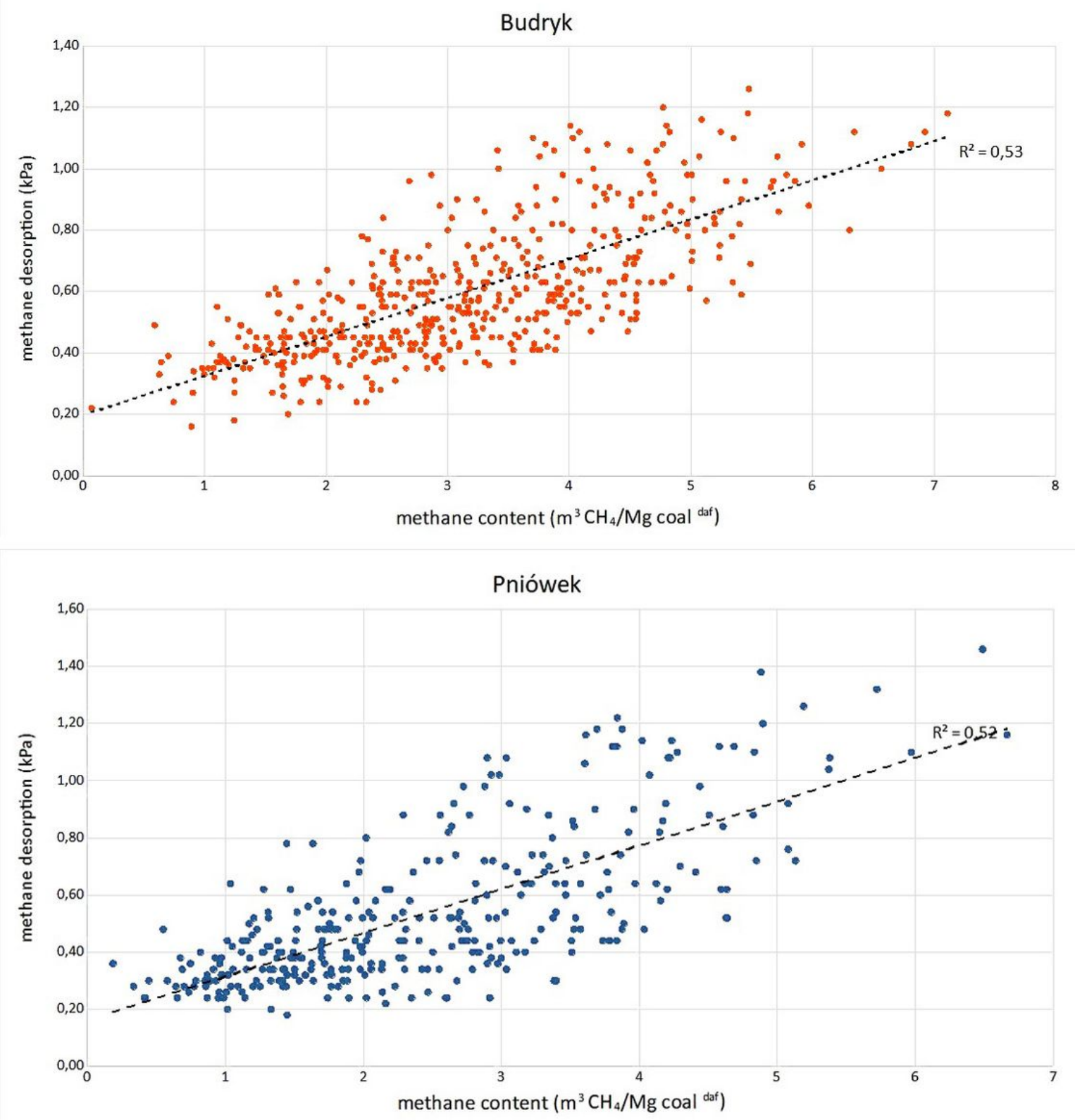

\section{Figure 9}

a The methane content and coal seam pressure studied on Budryk's coals by the CLP-B Mining Laboratory $b$ The methane content and coal seam pressure studied on Pniówek's coals by the CLP-B Mining Laboratory 


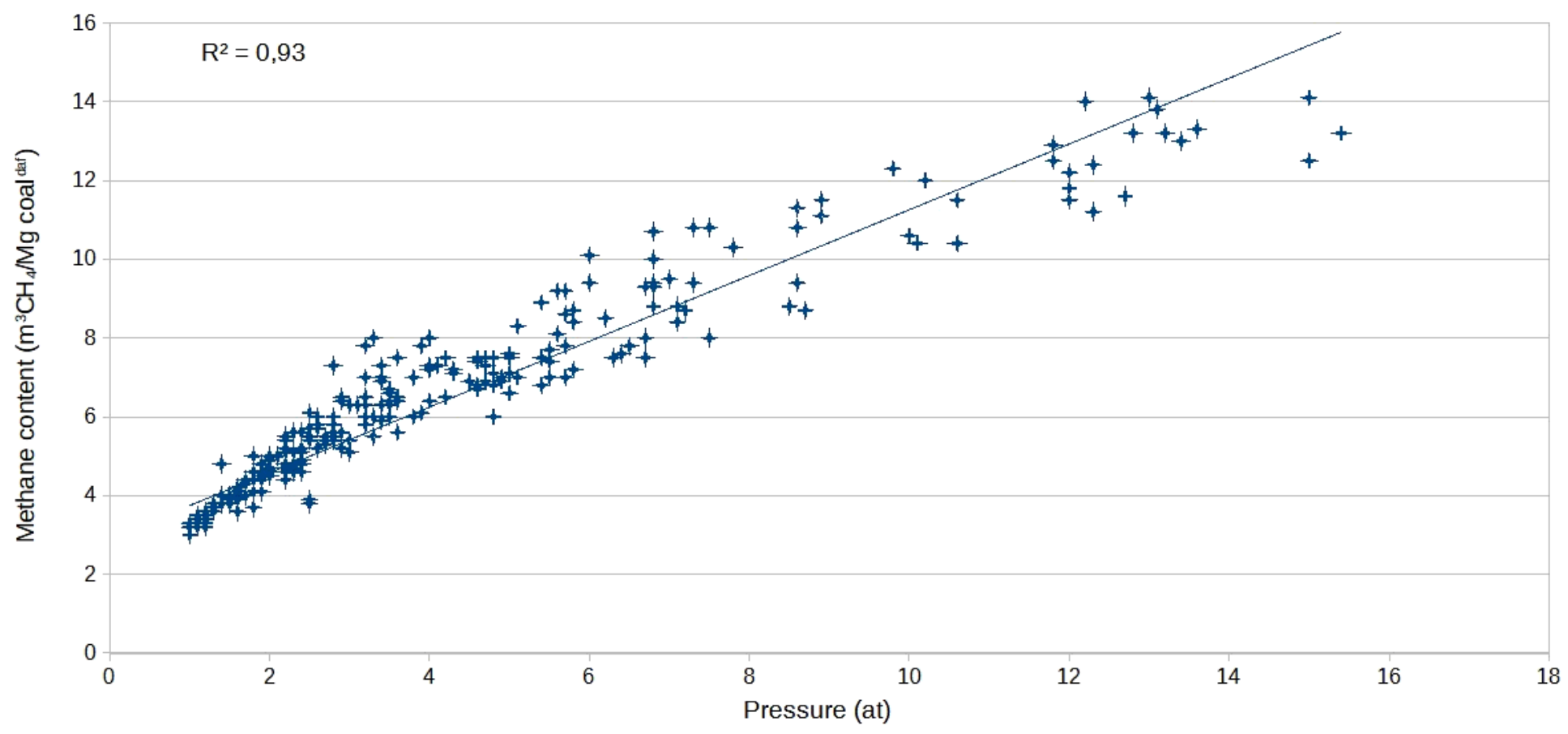

\section{Figure 9}

The methane content and coal seam pressure studied in the USCB coal mines (Tarnowski 1971)

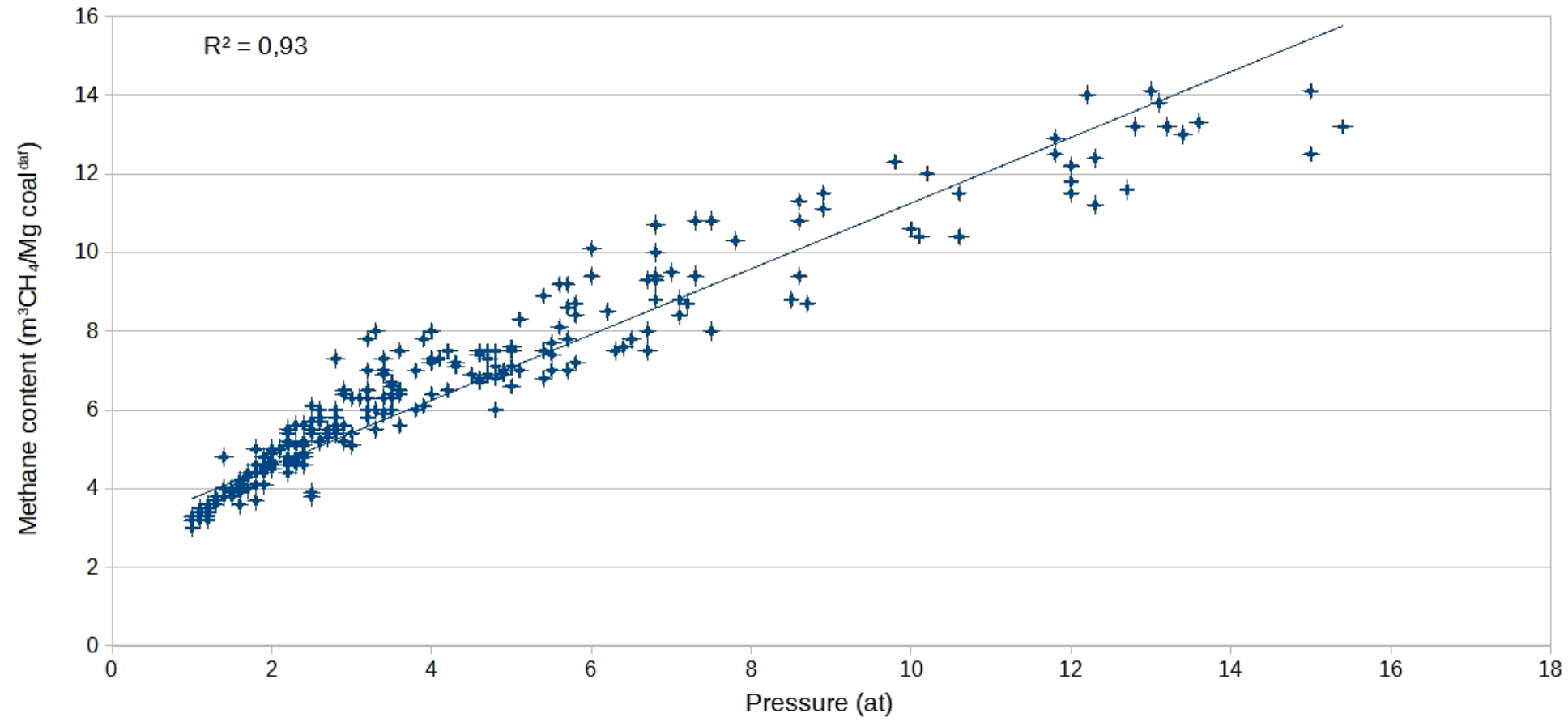

\section{Figure 9}

The methane content and coal seam pressure studied in the USCB coal mines (Tarnowski 1971) 

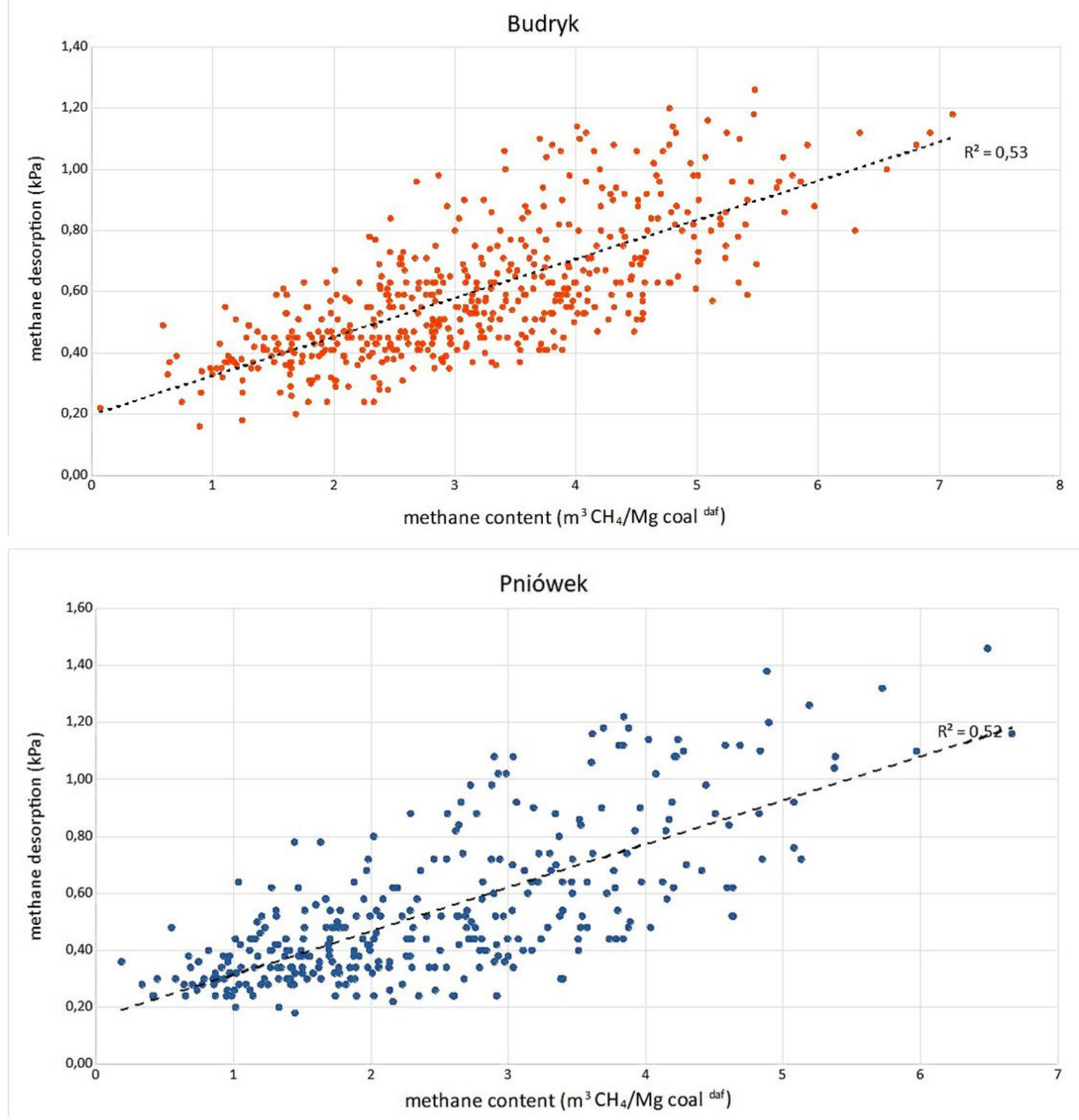

Figure 10

a The methane content and coal seam pressure studied on Budryk's coals by the CLP-B Mining Laboratory b The methane content and coal seam pressure studied on Pniówek's coals by the CLP-B Mining Laboratory 


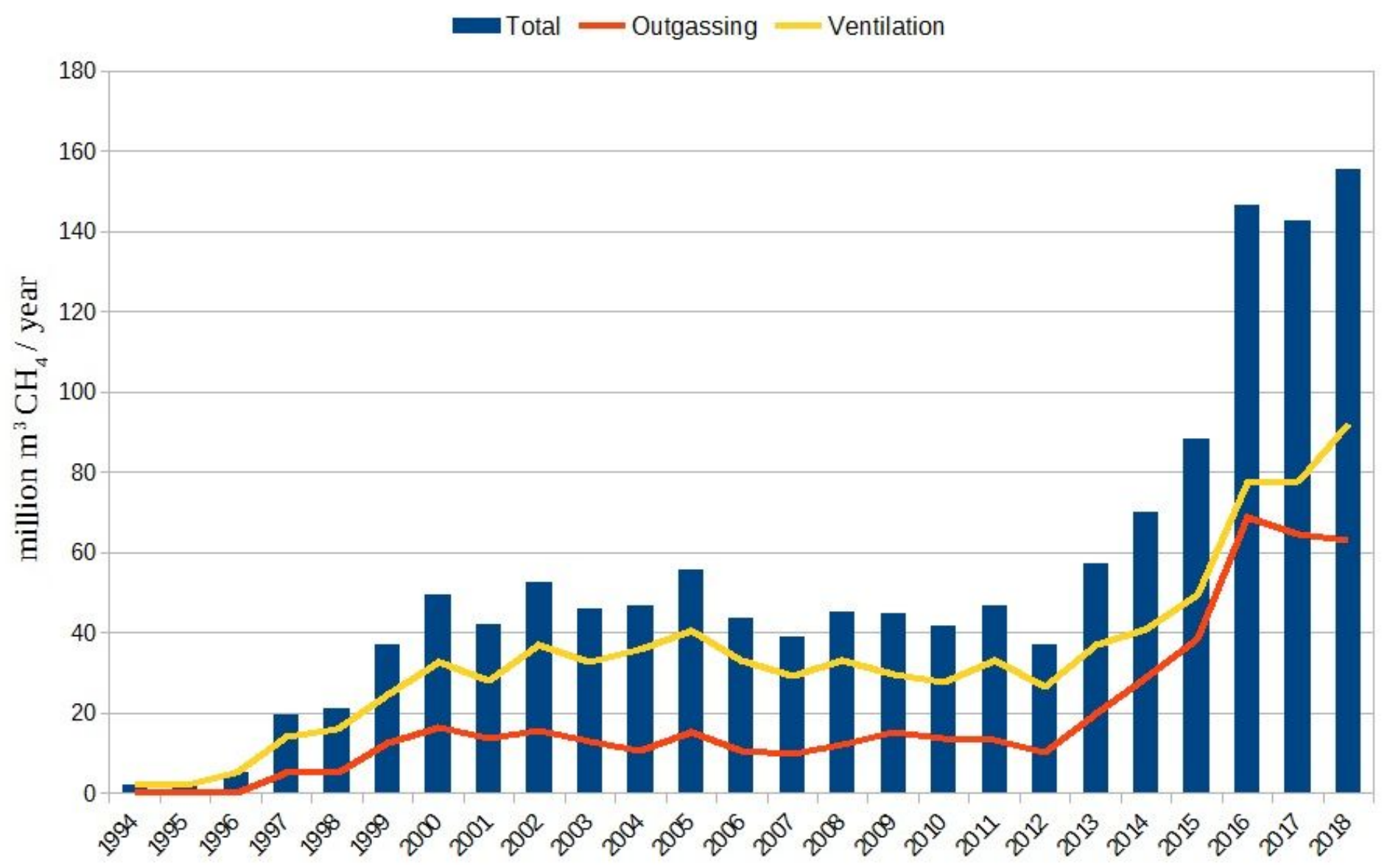

Figure 10

The Budryk mine methane emissions (JCC internal report)

ロBydryk 口Pniówek

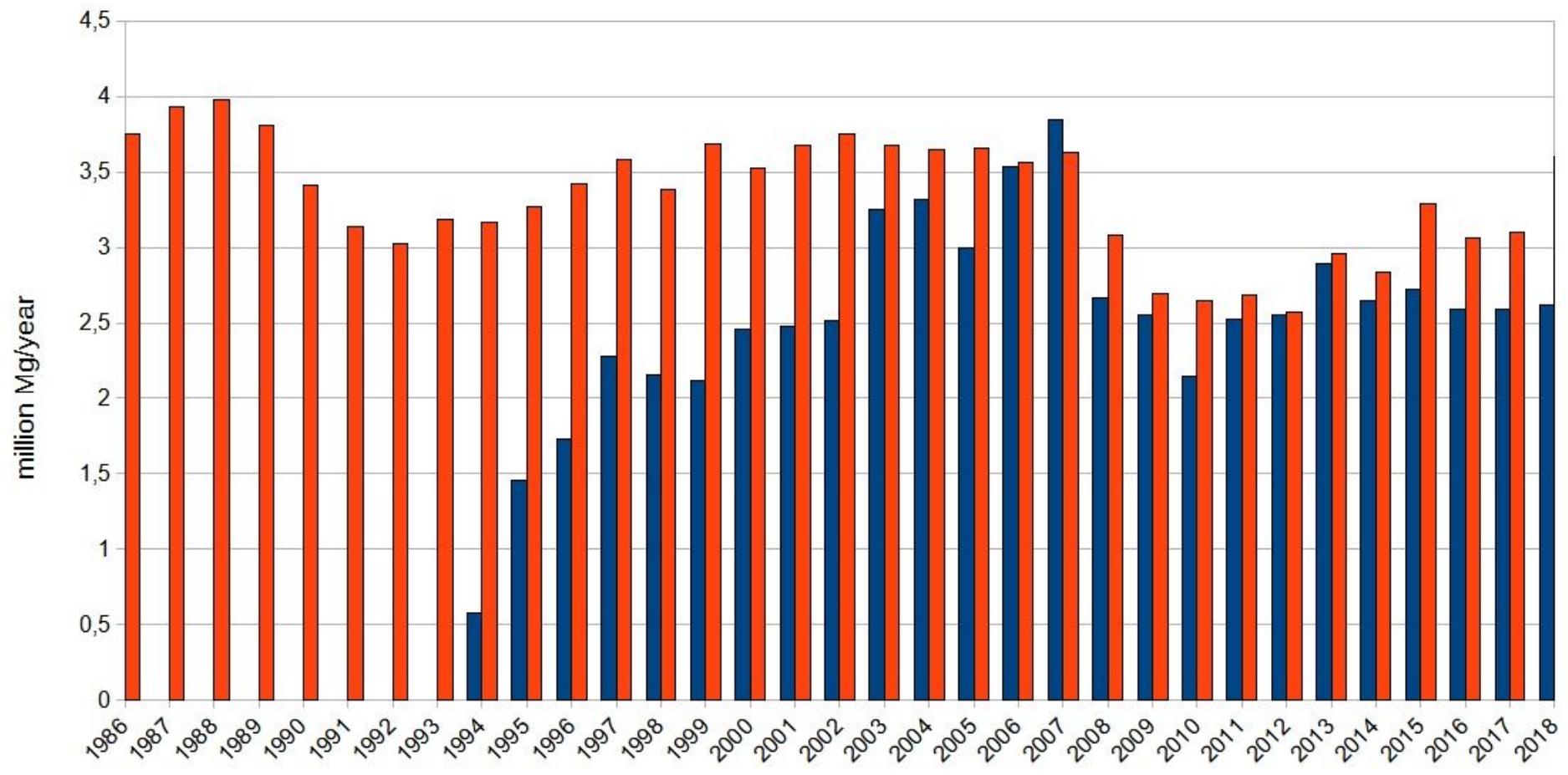

Figure 10 


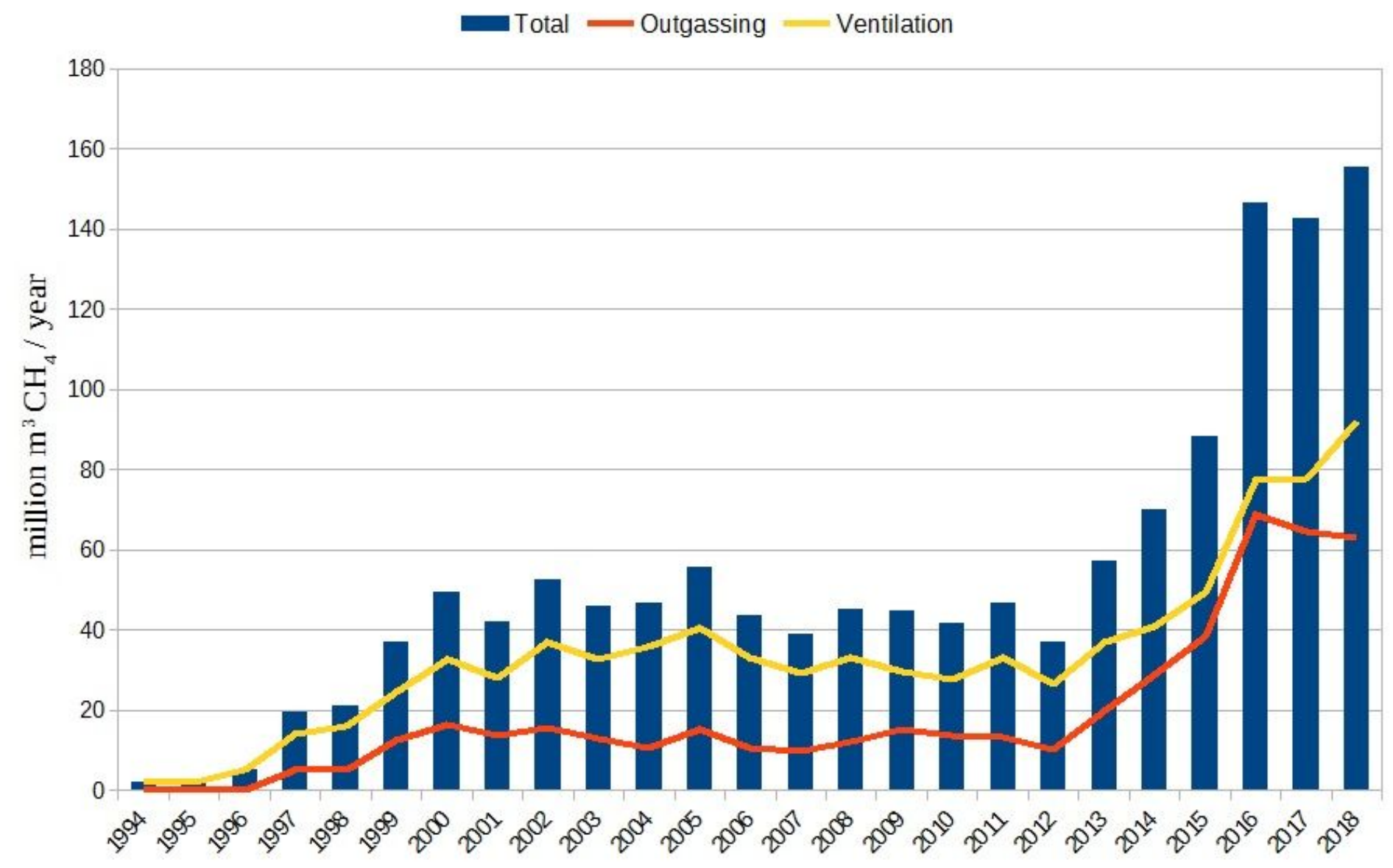

Figure 10

The Budryk mine methane emissions (JCC internal report)

ロBydryk 口Pniówek

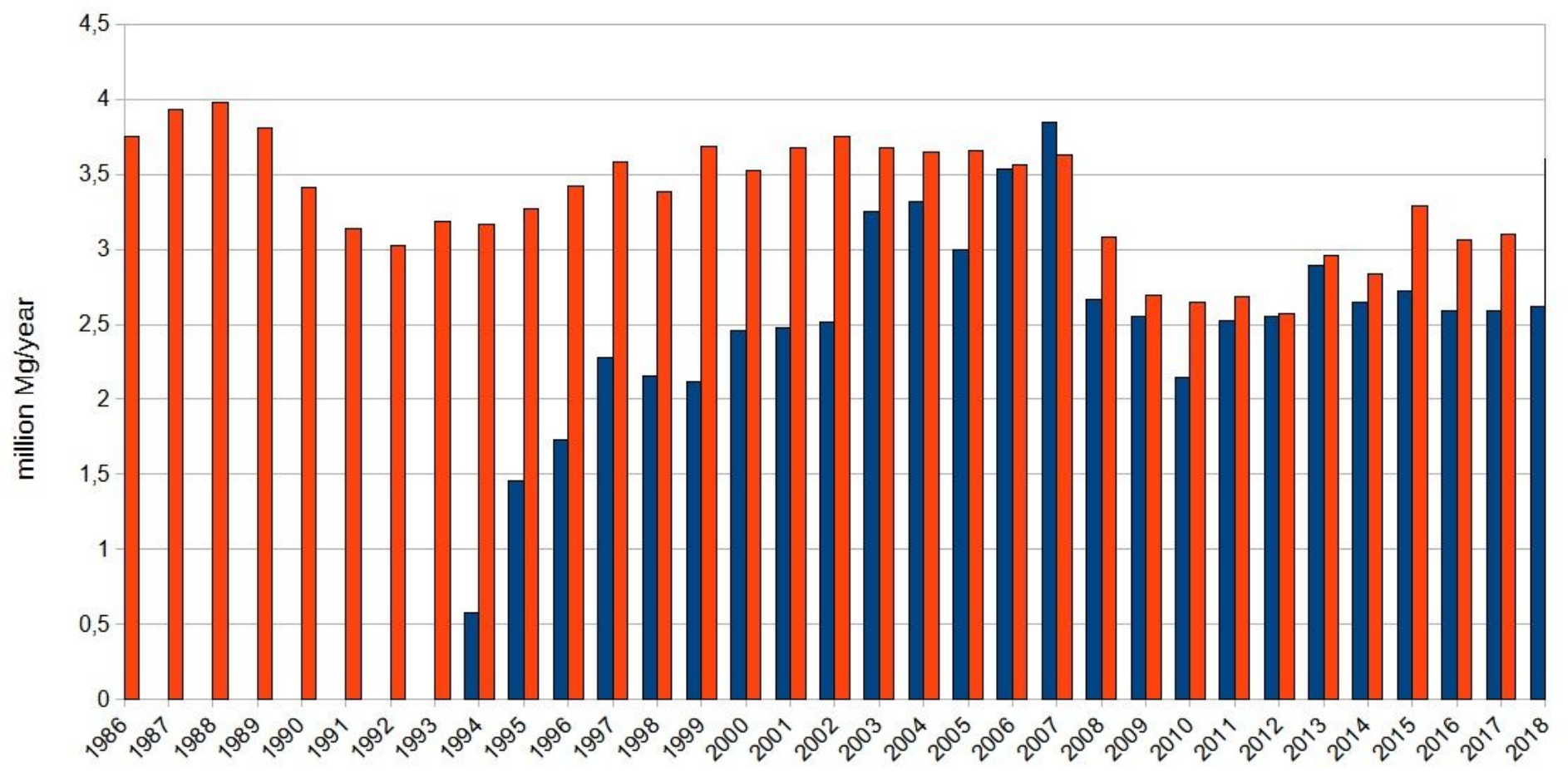


Figure 11

The Budryk and Pniówek hard coal output (JCC internal report)

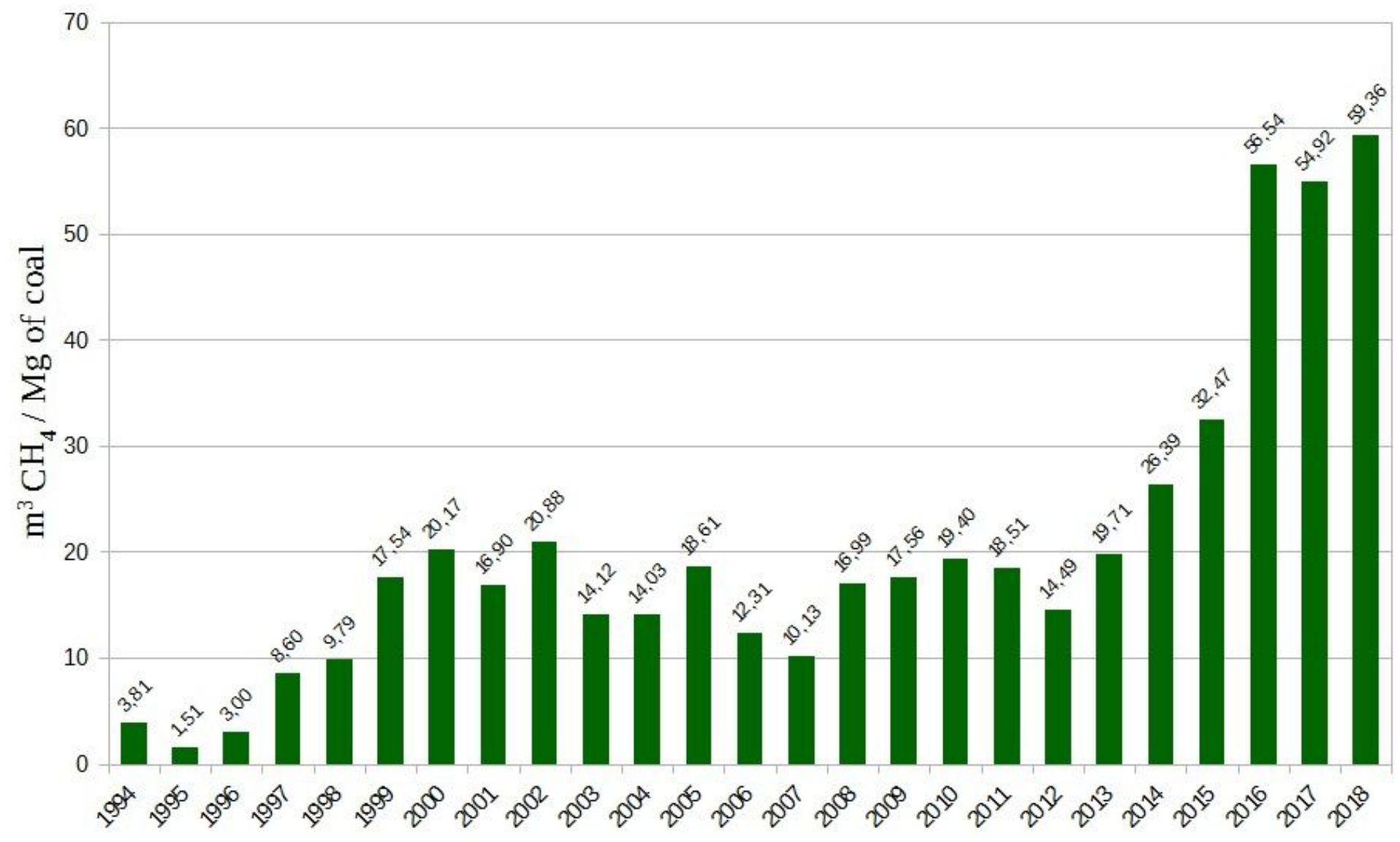

Figure 13

The Budryk mine specific methane emission (JCC internal report) 


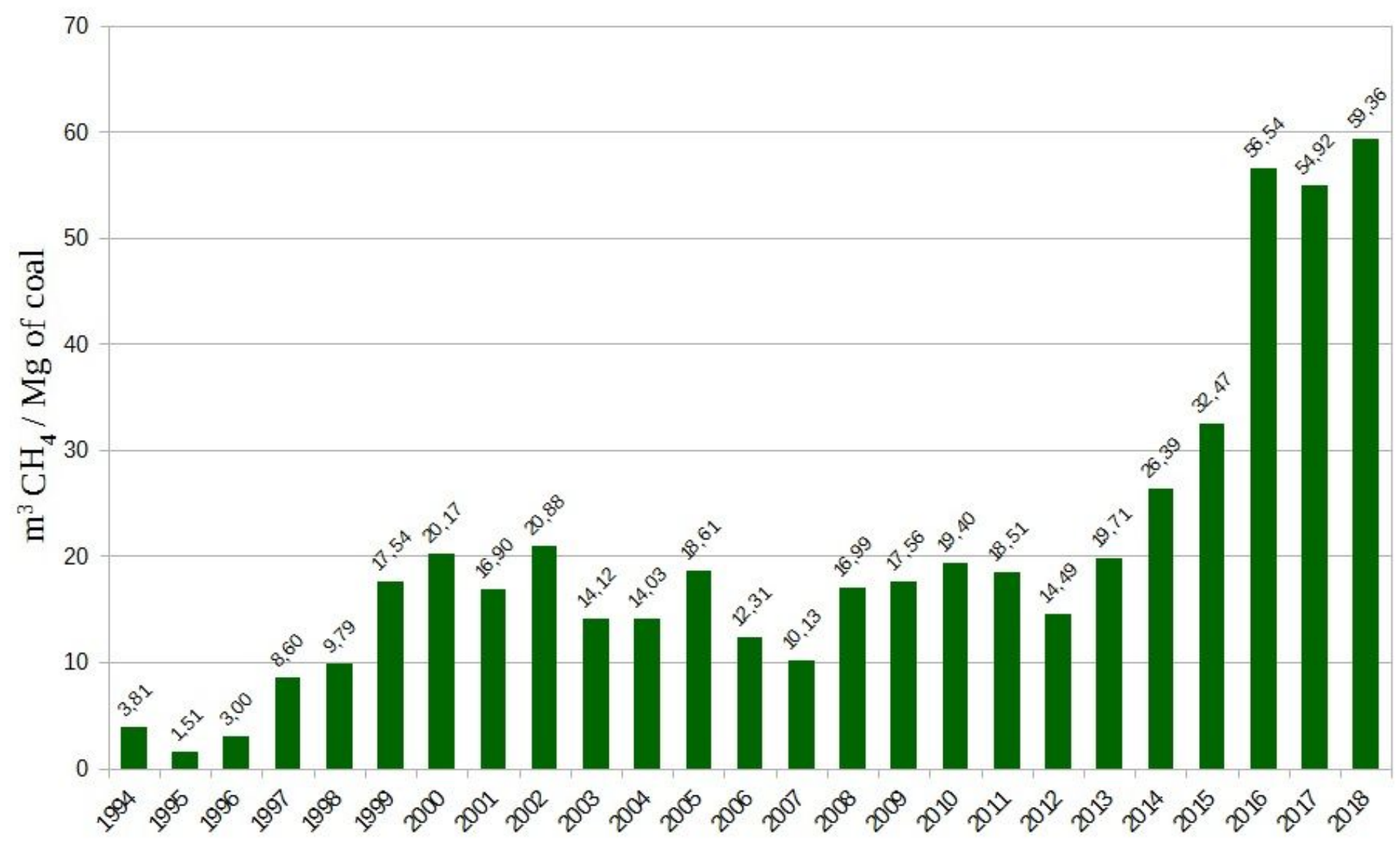

Figure 13

The Budryk mine specific methane emission (JCC internal report)

घydryk 口Pniówek

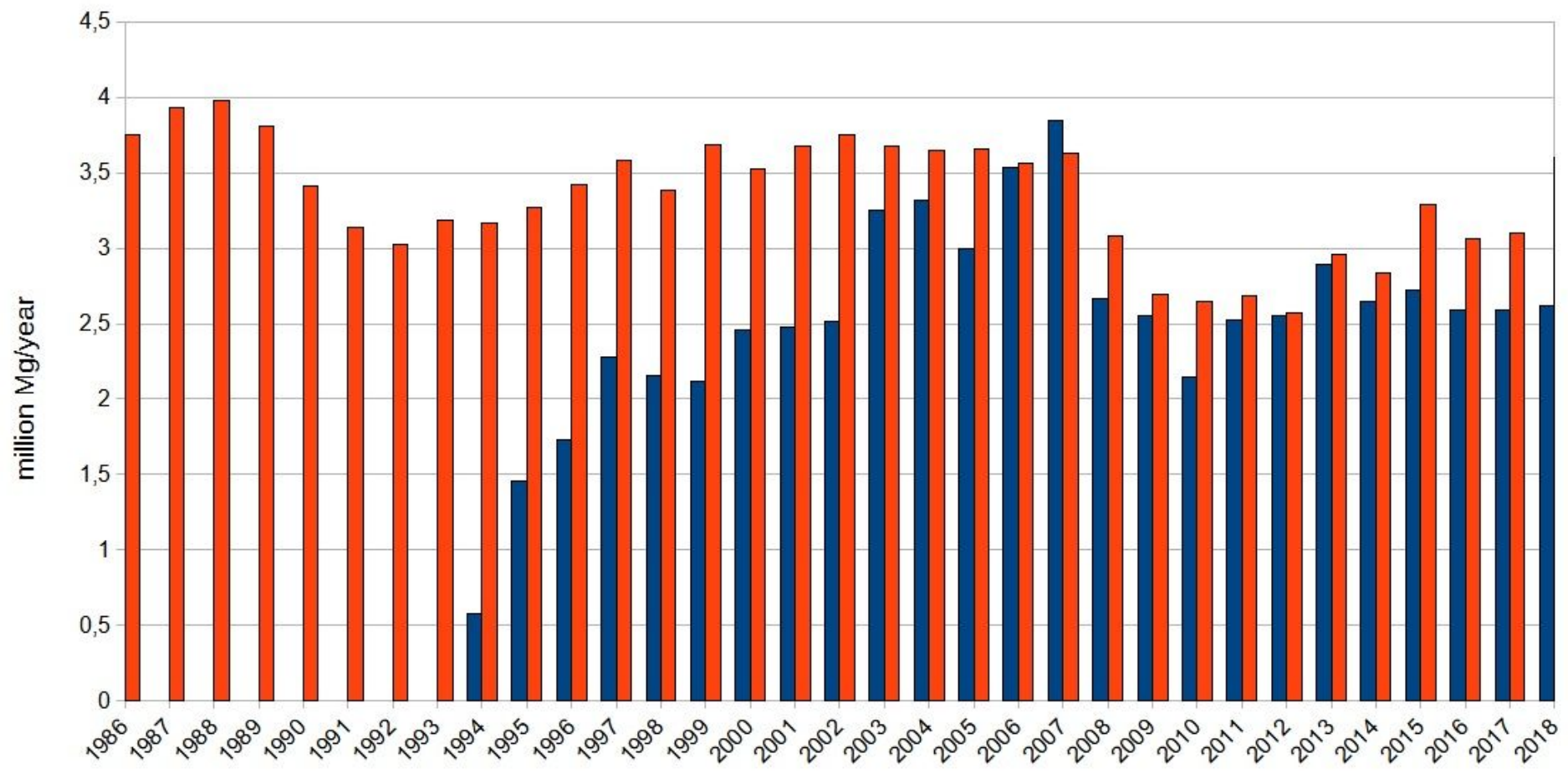

Figure 13 


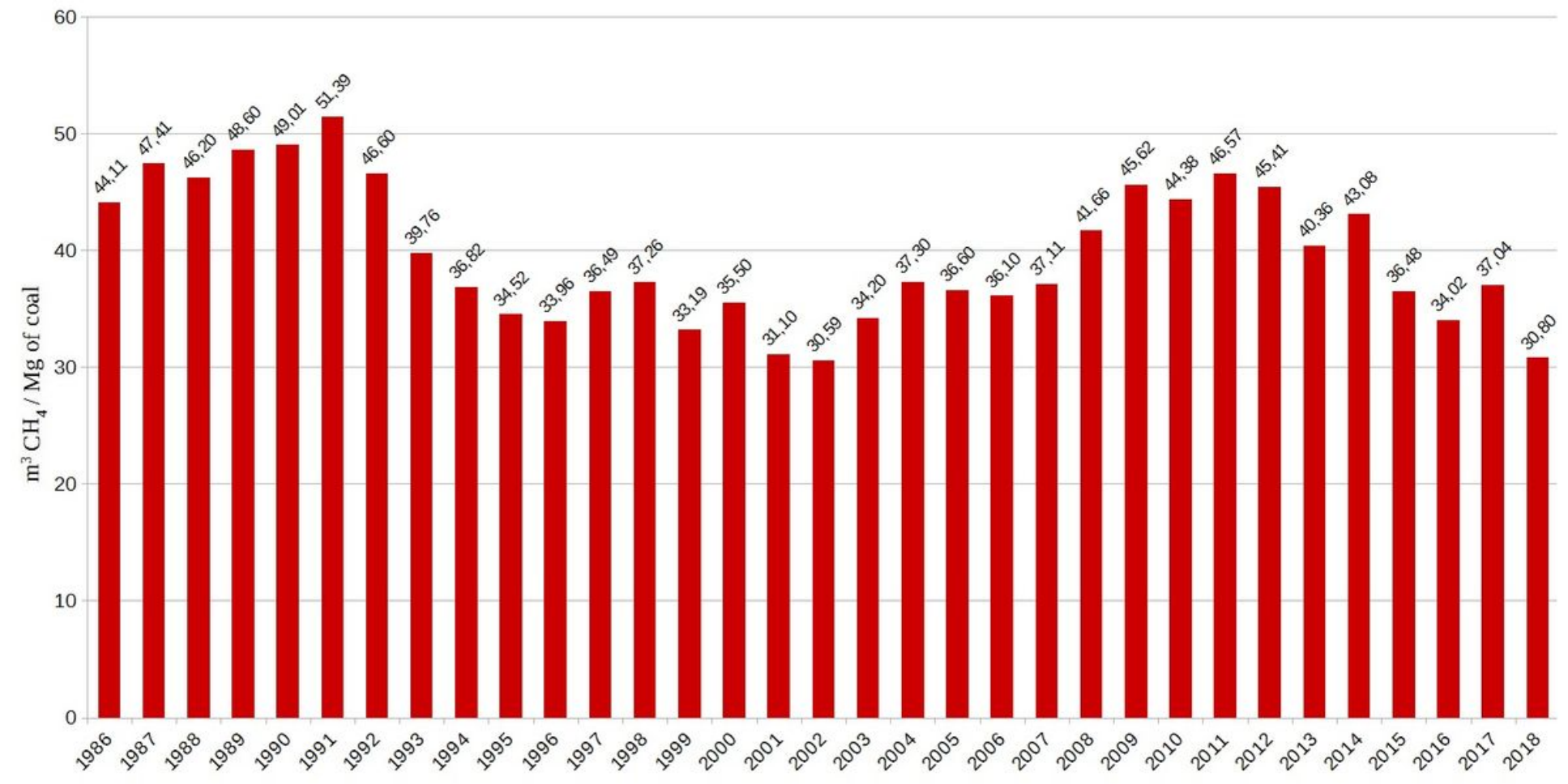

Figure 13

The Pniówek mine methane emissions (JCC internal report) 


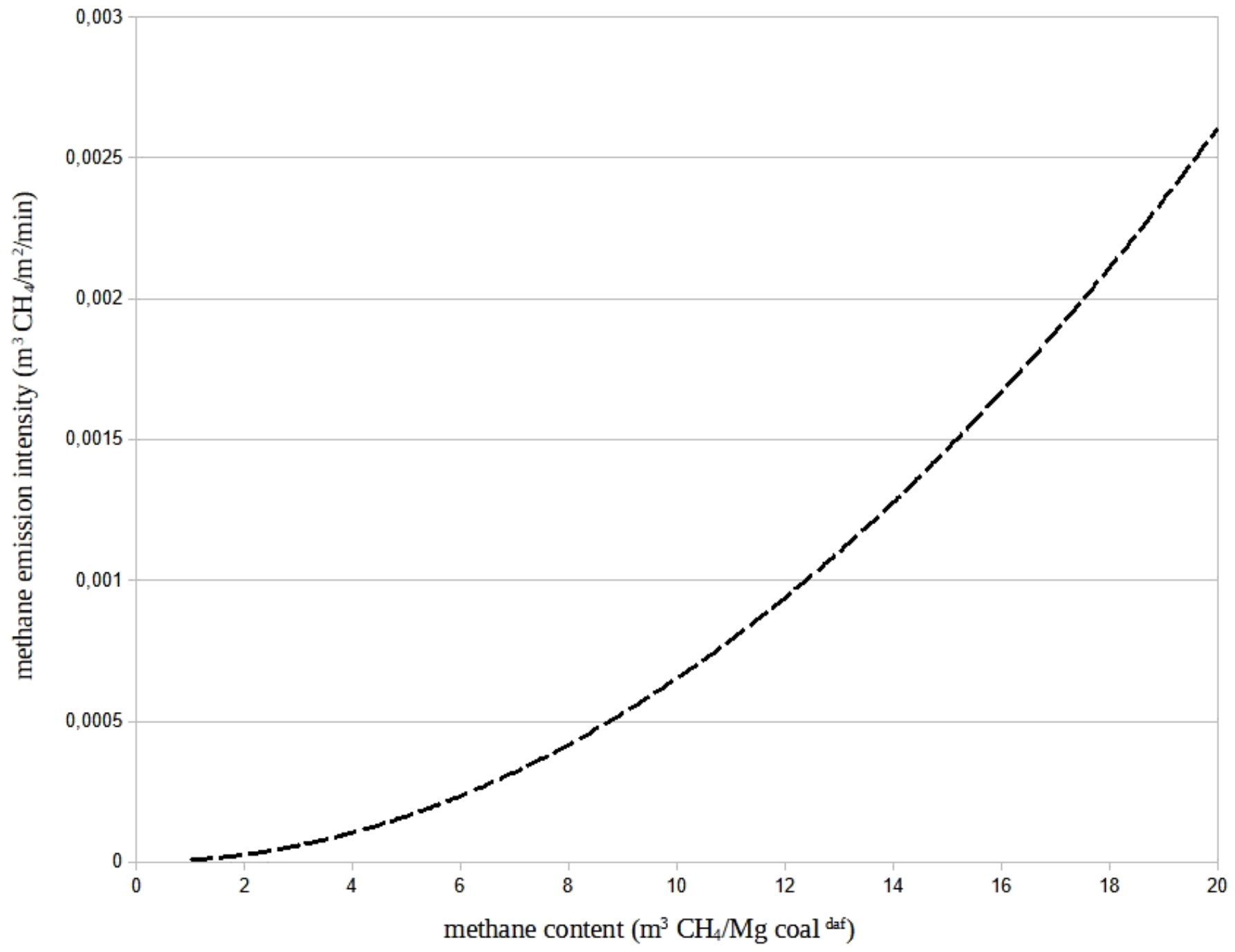

Figure 14

Methane emission intensity from the coal surface (Kozłowski 1982, 1986; Krause 2019) 


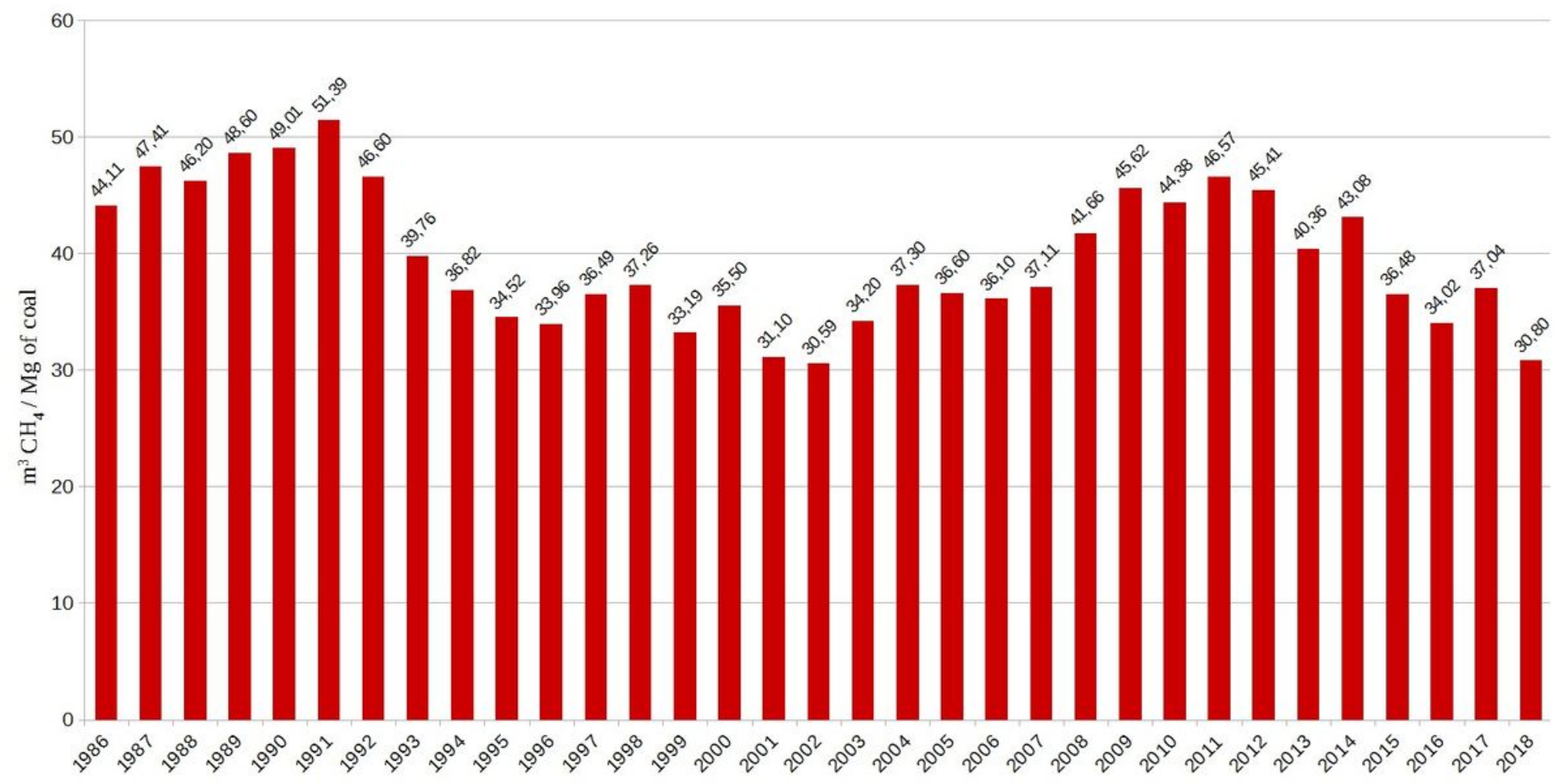

Figure 14

The Pniówek mine methane emissions (JCC internal report)

ロBydryk 口Pniówek

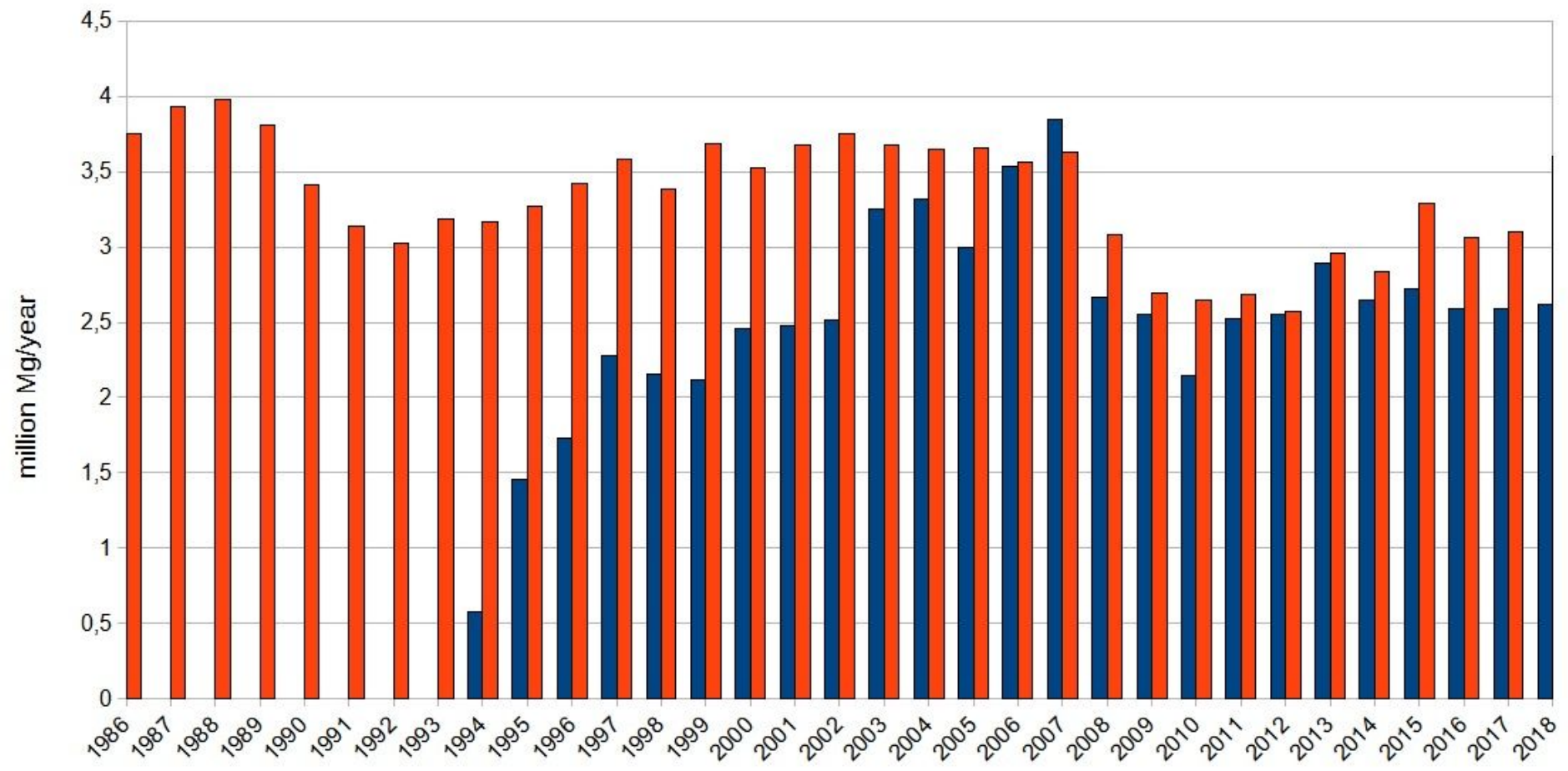

Figure 14

The Pniówek mine specific methane emission (JCC internal report) 


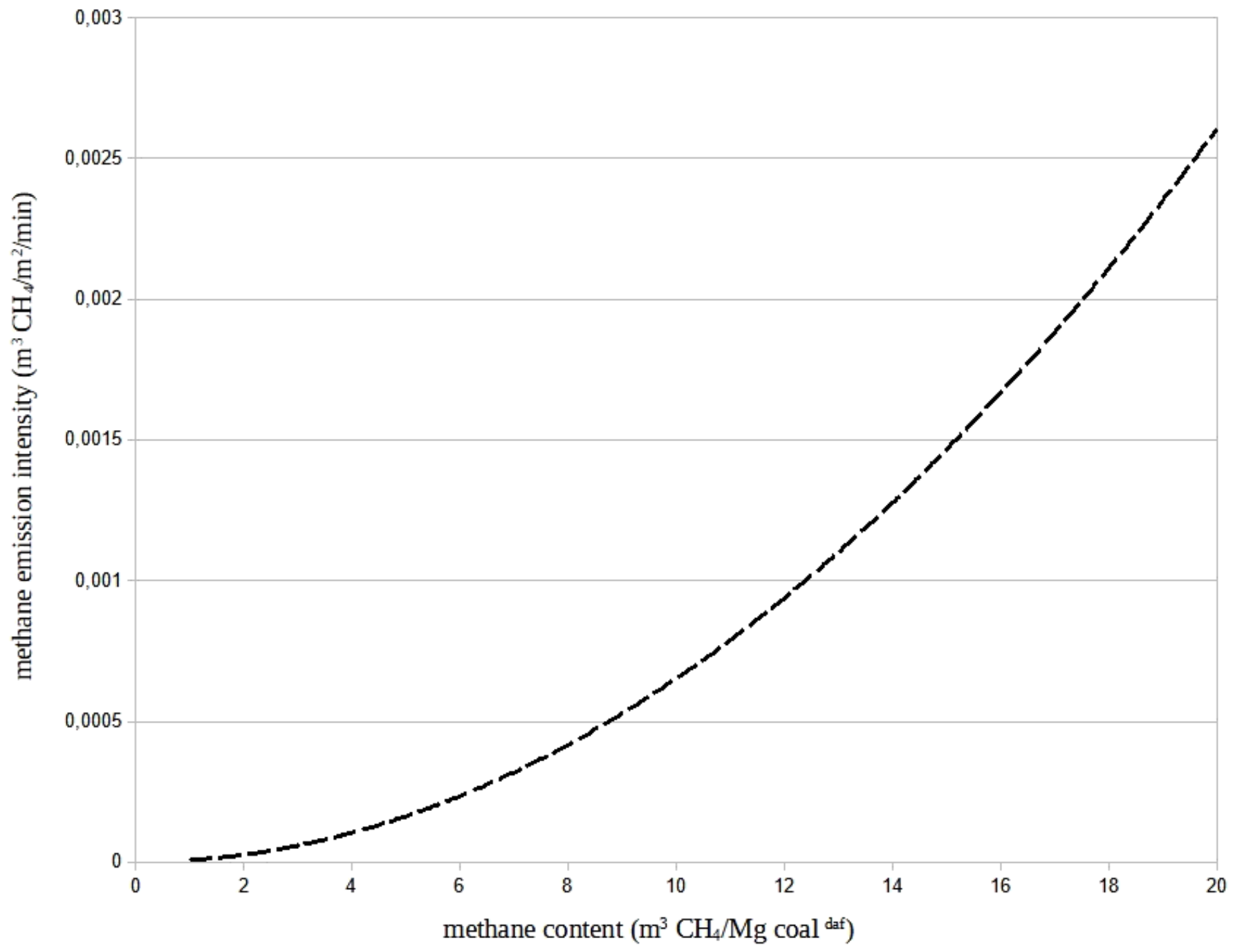

Figure 14

Methane emission intensity from the coal surface (Kozłowski 1982, 1986; Krause 2019) 


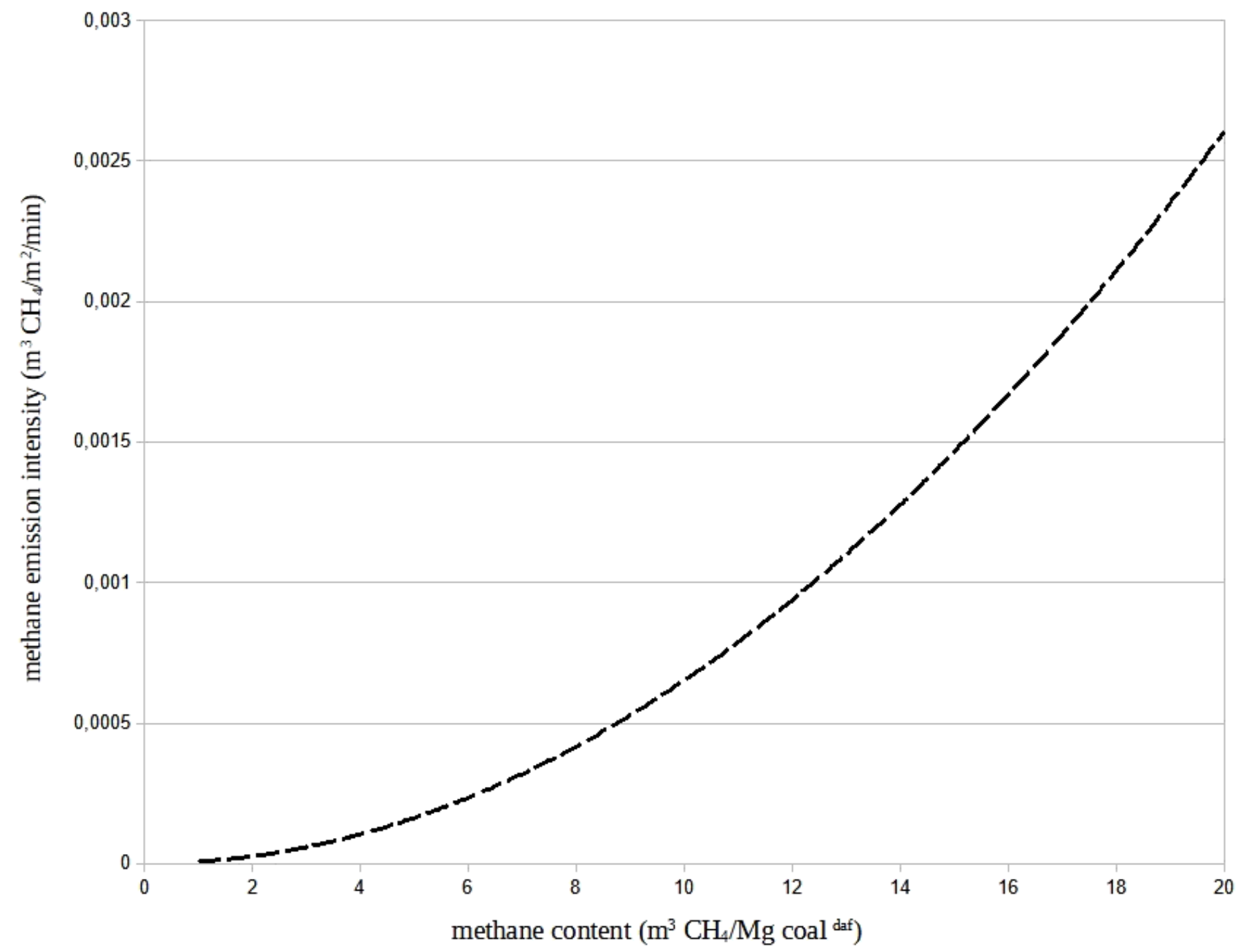

Figure 16

Methane emission intensity from the coal surface (Kozłowski 1982, 1986; Krause 2019) 


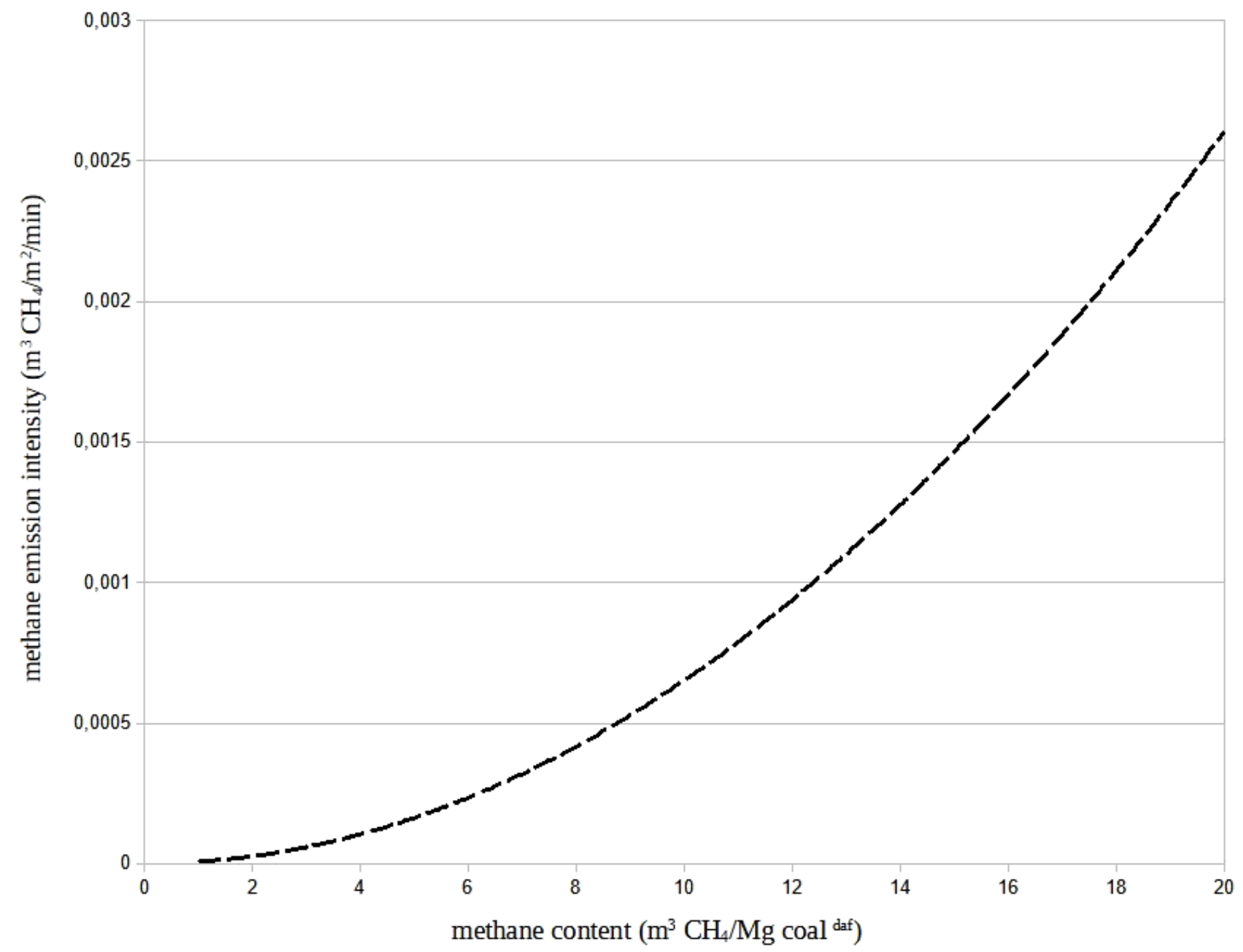

Figure 16

Methane emission intensity from the coal surface (Kozłowski 1982, 1986; Krause 2019) 